cPA-600/2-76-025

February 1976
ORNL/TM-5423 Environmental Protection Technology Series

\title{
CROSS-FLOW FILTRATION IN
PHYSICAL-CHEMICAL TREATMENT OF \\ CROSS-FLOW FILTRATION IN
PHYSICAL-CHEMICAL TREATMENT OF MUNICIPAL SEWAGE EFFLUENTS
}

'repared by

OAK RIDGE NATIONAL LABORATORY OPERTIED BY URION CARGiOE CORPORATIOH FOR THE EMERGY RESEARCH ANO DEVELOPWEMT ADMIWISTRATION MASTER

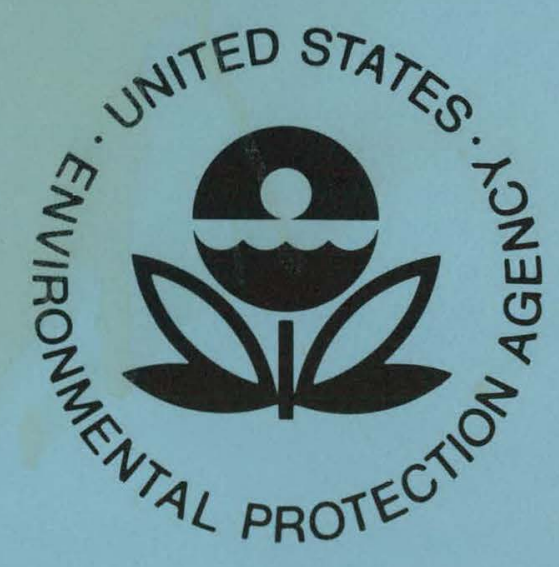

Prepared for

Municipal Environmental Research Laboratory Office of Research and Development U.S. Environmental Protection Agency Cincinnati, Ohio 45268 


\section{DISCLAIMER}

This report was prepared as an account of work sponsored by an agency of the United States Government. Neither the United States Government nor any agency Thereof, nor any of their employees, makes any warranty, express or implied, or assumes any legal liability or responsibility for the accuracy, completeness, or usefulness of any information, apparatus, product, or process disclosed, or represents that its use would not infringe privately owned rights. Reference herein to any specific commercial product, process, or service by trade name, trademark, manufacturer, or otherwise does not necessarily constitute or imply its endorsement, recommendation, or favoring by the United States Government or any agency thereof. The views and opinions of authors expressed herein do not necessarily state or reflect those of the United States Government or any agency thereof. 


\section{DISCLAIMER}

Portions of this document may be illegible in electronic image products. Images are produced from the best available original document. 


\section{RESEARCH REPORTING SERIES}

Research reports of the Office of Research and Development, U.S. Environmental Protection Agency, have been grouped into five series. These five broad categories were established to facilitate further development and application of environmental technology. Elimination of traditional grouping was consciously planned to foster technology transfer and a maximum interface in related fields. The five series are:

1. Eivirunmental Health Effects Research

2. Environmental Protection Technology

3. Ecological Hesearch

4. Environmental Monitoring

5. Socioeconomic Environmental Studies

This report has been assigned to the ENVIRONMENTAL PROTECTION TECHNOLOGY series. This series describes research performed to develop and demonstrate instrumentation, equipment, and methodology to repair or prevent environmental degradation from point and non-point sources of pollution. This work provides the new or improved technology required for the control and treatment of pollution sources to meet environmental quality standards.

Printed in the United States of America. Available from National Technical Information Service

U.S. Department of Commerce

5285 Port Royal Road, Springfield, Virginia 22161

Price: Printed Copy $\$ 6.00$; Microfiche $\$ 2.25$

This report was prepared as an account of work sponsored by the United States Government. Neither the United States nor the Energy Research and Development Administration, nor any of their employees, nor any of their contractors, subcontractors, or their employees, makes any warranty, express or implied, or assumes any legal liability or responsibility for the accuracy, completeness or usefulness of any information, apparatus, product or process disclosed, or represents that its use would not infringe privately owned rights. 
Contract No. W-7405-eng-26

Chemistry Division

CROSS-FLOW FILTRATION IN PHYSICAL-CHEMICAL TREATMENT

OF MUNICIPAL SEWAGE EFFLUENTS

by

H. A. Mahlman, W. G. Sisson, K. A. Kraus, and J. S. Johnson, Jr'. Oak Ridge National Laboratory

Oak Ridge, Tennessee 37830

Contract WQO 14-12-832

AEC Interagency Agreement 40-191-69

Project Officer

Warren A. Schwartz

Municipal Environmental Research Laboratory

Cincinnati, Ohio 45268

February 1976

Prepared for

U.S. ENVIRONMENTAL PROTECTION AGENCY OFFICE OF RESEARCH AND DEVELOPMENT

MUNICIPAL ENVIRONMENTAL RESEARCH LABORATORY CINCINNATI, OHIO 45268

\section{Prepared by}

OAK RIDGE NATIONAL LABORATORY

Oak Ridge, Tennessee 37830

operated by

UNION CARBIDE CORPORATION

for the

ENERG' $I$ REBEARCH AND DEVELOPMENT ADMIINISTRATION 
This report has been reviewed by the Municipal Environmental Research Laboratory, U.S. Environmental Protection Agency, and approved for publication. Approval does not signify that the contents necessarily reflect the views and policies of the U.S. Environmental Protection Agency, nor. does mention of trade names or commercial products constitute endorsement or recommendation for use. 
FOREWORD

Man and his environment must be protected from the adverse effects of pesticides, radiation, noise, and other forms of pollution, and the unwise management of solid waste. Efforts to protect the environment require a focus that recognizes the interplay between the components of our physical environment--air, water, and land. The Municipal Environmental Research Laboratory contributes to this multidisciplinary focus through programs engaged in

studies on the effects of environmental contaminants on the biosphere, and

a search for ways to prevent contamination and to recycle valuable resources.

This report deals with development of technology for municipal sewage treatment.

Louis W. Lefke

Acting Director

Municipal Environmental Research

Laboratory 
In separations of solids from liquids by filtration, the motion of liquid is customarily normal to the filtering surface, and solids are left on the filter. In a variation called by $K$. A. Kraus "cross-flow filtration," liquid is pumped parallel to the filtering surface. By this device, thickening of flux-limiting filtercake is slowed, and the original stream is separated into a large volume of filtrate and a concentrated slurry of solids. Results reported here were obtained in cross-flow filtration used as an element in physical-chemical treatment of municipal sewage, mostly with the effluent from primary settling, but in some cases, with clarified activated sludge effluent as feed.

Filtrate from passage through fabric tubes (1-inch fire-hose jackets) of primary effluent, treated with iron or aluminum salts, with powdered activated carbon (PAC), or with both hydrolyzable ions and PAC, was generally of quality superior in turbidity, organic carbon and other respects to the effluent from biological secondary treatment. Effects on product quality and flux of pressure, clrculation velocity, additive concentration, water recovery, $\mathrm{pH}$ and other variables were investigated. Based on production rates obtained, estimates of treatment costs were made.

This report was submitted in fulfillment of WQO Order \#14-12-832 by the Water Research Program, Oak Ridge National Laboratory, under the partial sponsorship of the Environmental Protection Agency. 
CONTENTS

Foreword . . . . . . . . . . . . . . . . . . . iii

Abstract ............................. iv

List of Figures . . . . . . . . . . . . . . . . . . . . vi

List of Tables . . . . . . . . . . . . . . . . . . . ix

Acknowledgments . . . . . . . . . . . . . . . . x

Sections

Conclusions . . . . . . . . . . . . . . . . . . . . 1

Recommendations . . . . . . . . . . . . . . . 3

Introduction . . . . . . . . . . . . . . . . . . . . 4

Equipment and Experimental Methods . . . . . . . . . . 8 Cross-Flow Filtration Equipment . . . . . . . . . . . 8

Test Sections....................... 10

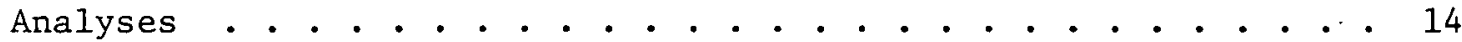

The Oak Ridge Municipal East Sewage Plant . . . . . . . . . 16

The Oak Ridge National Laboratory Plant . . . . . . . . . . 20

Experimental Results . . . . . . . . . . . . . . . . . 21

Operation Variables... . . . . . . . . . . . . . . . 22

Effect of Cross-Flow Velocity . . . . . . . . . . . . 22

Effect of Pressure . . . . . . .. . . . . . . . 25

Effect of Water Recovery . . . . . . . . . . . . . 35

Effect of Temperature . . . . . . . . . . . . . . . . 41

Effect of Additives... . . . . . . . . . . . . . . . 41

Removal of $\mathrm{P}(\mathrm{V})$ by Hydrolyzable Ion Addition . . . . . . . . . 41

Effects of Hydrolyzable Ions and $\mathrm{pH}$ on Flux . . . . . . . . . . 44

Use of Lime for Neutralization . . . . . . . . . . . . . . 60

Quality of Cross-Flow Filtrates from Effluents . . . . . . 66

Powdered Activated Carbon . . . . . . . . . . . . . . . 75

Two-Stage Proccssing by Hydrolyzable Ions Followed by PAC . . . 79

Porous Supports, Precoats, and Regeneration . . . . . . . . . 83

Discussion . . . . . . . . . . . . . . . . . . . 89

Costs.............................. 91

Cross-Flow Filtration . . . . . . . . . . . . . . . . 91

Cost of Chemicals.. . . . . . . . . . . . . . . . . . 94

Other Costs... . . . . . . . . . . . . . . . . . 103

Comments . . . . . . . . . . . . . . . . . . . 103

Future Work . . . . . . . . . . . . . . . . . . 106

Rcferences . . . . . . . . . . . . . . . . . . . . 109

Publications and Patents . . . . . . . . . . . . . . 114

Symbols and Abbreviations . . . . . . . . . . . . . . . 115 
No. $\quad$ Page

1 Schematic of Cross-Flow Filtration Test Unit . . . . . . . . . . 9

2 Cross-Flow Filtration Element . . . . . . . . . . . . . 11

3 Cross-Flow Filtration Unit Installed in Laboratory Loop . . . . . 12

4 Multielement External Flow Cross-Flow Filtration Installed in Mobile Unit . . . . . . . . . . . . . . . 13

5 Cross-Flow Filtration Test Module, Internal Flow Through Fire Hose Jacket . . . . . . . . . . . . . 15

6 Comparison of TOC Analyses of Primary Sewage by Different Procedures ....................... 17

7 Variation of Constituents in Primary Sewage, Oak Ridge Municipal Plant: 1970-71 . . . . . . . . . . . 18

8 Primary Sewage Analyses, Oak Ridge Municipal Plant: Daily Variation . . . . . . . .............. 19

9 Fluxes in Filtration of Primary Sewage with and without Cross-flow .................... 23

10 Cross-Flow Filtration of Primary Sewage: Effect of Circulation Velocity . . . . . . . . . . . . . . . 24

11 Cross-Flow Filtration of Primary Sewage . . . . . . . . . . . . 27

12 Cross-Flow Filtration of Primary Sewage with Powdered Artivated Carbon . . . . . . . . . . . . . .. . 28

13 Flux as a Function of Average Pressure in Cross-Flow Filtration of ORNL Sewage. . . . . . . . . . . . 30

14 Fluxes for Different Combinations of Pressure and Circulation Velocity . . . . . . . . . . . . . . . . . . . 31

15 Approximate Pumping Energy Requirements in Cross-FlowFiltration ................. . . 32

16 Fluxes of Aged and Fresh Pairs of Modules . . . . . . . . . 34

17 Low-Pressure, Low-Circulation-Velocity Cross-Flow Filtration of Primary Sewage . . . . . . . . . . . 36

18 Comparison of Fluxes During Initial Stages of Several Runs: Pilot Unit at ORNL Sewage Plant . . . . . . . . 37

19 Fluxes, Precoated and Non-Precoated Modules . . . . . . . . . 38

20 Flux Decline at Different Pressures and Recoveries . . . . . . 39

21 Fluxes at High Water Recovery . . . . . . . . . . . . . 40

22 Effect of Temperature on Flux . . . . . . . . . . . . . 42 
23 Dependence of Phosphate in Filtrate on Ratio of Phosphate to Ferric in Feed . . . . . . . . . . . . . . . 43

24 Effect of Ratio of Al(III) to Polyacrylate on Flux in Filtration . . . . . . . . . . . . . . . . 45

25 Cross-Flow Filtration of Primary Sewage with and without Fe(III) Addition . . . . . . . . . . . . . . . . 47

26 Fluxes at Two Hours, Cross-Flow Filtration of Sewage Effluents........................ 4 48

27 Correlation of Flux and Filtrate Quality with $\mathrm{Fe}($ III) . . . . . 49

28 Correlation of Flux and Filtrate Quality with Fe(III) and Organic Carbon Level . . . . . . . . . . . . . 51

29 Correlation of Average Flux with Organic Carbon in.Feed . . . . . 52

30 Correlation of Average Flux with Organic Carbon in Filtrate . . . 53

31 Fluxes at Two Hours, Cross-Flow Filtration of Primary Sewage • 54

32 Correlation of Flux and Filtrate Quality with Fe(III) Addition: Set II . . . . . . . . . . . . . . . 55

33 Correlation of Flux and Filtrate Quality with Fe(III) and Organic Carbon in Primary Sewage: Set II . . . . . . . 56

34 Effect of Acidity on Cross-Flow Filtration Flux . . . . . . . . 58

35 Comparison of Initial Fluxes in Operation at $\mathrm{pH} 6$ and $\mathrm{pH} 7$.

36 Flux at Two Hours as Function of Al(III) Addition . . . . . . 662

37 Flux and Filtrate Quality with Al(III) Addition to Primary Sewage .................... 63

38 Flux and Filtrate Quality as Function of ppm AI(III) Addition per pPm TOC in Primary Sewage . . . . . . . . 64

39 Comparisull uf Cruss-Flow Filtration of Primary Sewage Neutralized with $\mathrm{CaO}$ after Addition of Iron Sulfate and Iron Chloride..................... 65

40 Phosphate and Metal Ion Leakage in Cross-Flow Filtration of Primary Sewage as a Function of $\mathrm{pH}$. . . . . . . . . 69

41 Filtration of $\mathrm{Fe}$ (total) with Time, after Introduction

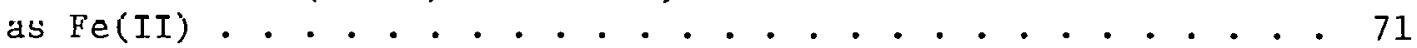

42 Iron Contamination of Fi.ltrate as a Function of $\Lambda$ cidity . . . . . 72

43 Adsorption of Organic Carbon from Filtrate of Fe(III)Treated Primary sewage afler Cruss-Flow Filtration . . . . . 77

44 Cross-Flow Filtration of Primary Sewage Effluent after Powdered Carbon Addition . . . . . . . . . . . . 78

45 Two-Stage Crosa-Flow Filtration of Primary Sewage: Low Initial PAC Addition . . . . . . . . . . . . . 80 
46 Two-Stage Cross-Flow Filtration of Primary Sewage: Medium Initial PAC Addition . . . . . . . . . . . . . . . . 81

47 Two-Stage Cross-Flow Filtration of Primary Sewage: High Initial PAC Addition . . . . . . . . . . . . . . . 82

48 Regeneration by Backwashing: Comparison of Precoats . . . . . 85

49 Regeneration by Backwashing: Successive Runs . . . . . . . . . 87

50 Regeneration of Firehose Jackets . . . . . . . . . . . . 88

51 Plan for a 1 Million Gallon per Day Cross-Flow Filtration Plant . . . . . . . . . . . . . . . . . . . 93

52 Elevation of a Cross-Flow Filtration Plant Module . . . . . . . . 98

53 Cross-Flow Filtration-Dependence of Operating Cost on Plant Size . . . . . . . . . . . . . . . . . . . . . 99

54 Cross-Flow Filtration-Dependence of Operating Cost on Flux . . . . . . . . . . . . . . . . . . . 100 


\section{TABLES}

No.

1 Effect of Cross-Flow Velocity on Flux in Filtration of Effluent from Primary Treatment of Sewage . . . . . . 26

2 Average Fluxes for the First 24 Hours of Operation . . . . . . 33

3 Comparison of Fluxes after Neutralization by $\mathrm{NaOH}$ and by $\mathrm{CaO}$. . . . . . . . . . . . . . . . . 61

4 Nitrogen Removal in Cross-Flow Filtration . . . . . . . . 73

5 Bacteria Contents of Cross-Flow Filtrates . . . . . . . . 75

6 Plant Characteristics . . . . . . . . . . . . . 92

7 Module Characteristics . . . . . . . . . . . . 95

8 Cross-Flow Filtration - Cost Summary (Non-Automated Plant) • . 96

9 Cross-Flow Filtration - Cost Summary (Automated Plant) . . . . 97

10 Estimated Typical Chemical Costs in Cross-Flow Filtration of Primary Sewage Effluent . . . . . . . . . . . . 104

11 Summary of Estimated Costs of Cross-Flow Filtration of Primary Sewage Effluent . . . . . . . . . . . 104 


\section{ACKNOWLEDGMENTS}

We are indebted for the cooperation of Oak Ridge municipal officials, in particular 0. K. Rickman, director of public works, Thomas C. Stephens, supervisor of sewage plants during the early phases of this program, and Jack Robinson, Jr., present supervisor. In operation of the pilot plant at the Laboratory sewage plant, we have benefited greatly by the participation of J. D. Hutchins, ORNL Operations Division, and of J. W. Tester, director, and R. W. Mayer, assistant director, of the Oak Ridge Station of the MIT School of Chemical Engineering Practice during the period when the work described in this report was carried out. Neva E. Harrison carried out the bulk of the analyses, and contributions of others are acknowledged at appropriate places in the report. Arthur J. Shor was most helpful in providing consultation concerning equipment. Editing and typing of this report was by Jane Beck, and figures were drafted by B. S. Dunlap.

We are grateful for the advice and support of Warren A. Schwartz, contract monitor, and J. M. Cohen of the U. S. Environmental Protection Agency. The work was also substantially supported by the U. S. Energy Research and Development Administration. We wish to thank in particular F. L. Culler, deputy Laboratory director, for his continued interest. 


\section{CONCLUSIONS}

1. Cross-flow filtration of primary effluent treated with Fe(III) or Al(III) produces filtrate typically containing 10 to $15 \mathrm{mg} / \mathrm{l}$ of total organic carbon (TOC), total phosphorus below $1 \mathrm{mg} / \ell$ (expressed as phosphate), and turbidity below 1 Jackson Turbidity Unit (JTU). With settled activated sludge effluent as feed, filtrate composition is similar, except that TOC is lower, usually about $5 \mathrm{mg} / \mathrm{l}$. Bacterial contents of filtrates are usually low.

2. Filtrate from primary effluent treated with powdered activated carbon (PAC) is of similar quality, except that little phosphate is removed, and TOC is usually lower, about $5 \mathrm{mg} / \ell$.

3. When $\mathrm{Fe}($ III) or $\mathrm{Al}$ (III) additions are used, unless $\mathrm{pH}$ is adjusted to the neutral range before filtration, filtrate is substantially contaminated with the additives.

4. An effluent low in phosphate and in TOC may be attained by a second-stage cross-flow filtration of PAC-treated filtrate from primary sewage, to which hydrolyzable ions had been added.

5. Fluxes increase with increasing cross-flow velocity. In operation at 4.6 meters/second $(\mathrm{m} / \mathrm{sec}$ ) or $15 \mathrm{feet} / \mathrm{second}$ (ft/sec), with Fe(III) or Al(III) additives, average fluxes of 6 meters/day (150 gallons per square foot per day $\left(\mathrm{gpd} / \mathrm{ft} \mathrm{t}^{2}\right)$ ) or higher seem attainable with 24 -hour intervals between backwashing or other regeneration procedures. Conflicting results have been obtained with respect to the effect on flux of $\mathrm{Fe}$ (III) additions above $50 \mathrm{mg} / \ell$.

6. If neither hydrolyzable ions nor PAC are added to primary effluent, fluxes in cross-flow filtration are much lower than if appropriate amounts of these additives are present. 
7. High concentrations of PAC in the solutions being filtered are necessary to attain favorable filtration rates. However, fresh primary sewage may be brought into the feed without further PAC additions to replace filtrate until the average amount of PAC used per volume treated is lowered to the range used in other tests of this reagent. For example, in a test in which 20 grams of PAC were added per liter of the initial charge of primary sewage, the average mg of PAC per liter of primary sewage processed in the first day was about 500, and the average flux was $\sim 16 \mathrm{~m} / \mathrm{d}\left(\sim 400 \mathrm{gpd} / \mathrm{ft}^{2}\right)$.

8. After initial transients, fluxes are not very dependent on pressure in the range studied, between 35,000 and 690,000 Newtons/meter ${ }^{2}$ $\left(\mathrm{N} / \mathrm{m}^{2}\right)$ or 5 and 100 pounds per square inch (psi).

9. Neither flux nor product quality are very sensitive to water recovery (fraction or percent of initlal feed volume in filtrate stream), at least up to $90 \%$.

10. Woven fabric tubes $(2.5-\mathrm{cm}$ (1-inch) diameter manufactured for use as fire-hose jackets) are suitable as filtering surfaces. In more limited tests, screens appeared to be acceptable alternatives. Fibrous filteraid precoats are necessary with coarse screens (perhaps < 100 mesh) and seem helpful with fire-hose jackets in maintaining ability to regenerate by backwashing in successive runs. There appears to be no signiticant difference in performance of fire-hose jackets when flow of the solution being filtered is outside (pressure support inside) or inside (no support). 11. For a $3800 \mathrm{~m}^{3} / \mathrm{d}\left(10^{6} \mathrm{gpd}\right)$ plant and for average fluxes in the lower range of those obtained in this study, preliminary estimates indicate costs of cross-flow filtration of primary sewage with ferric chemical treatment are about $12 \mathrm{c} / \mathrm{m}^{3}$ or $45 \mathrm{c} / \mathrm{kgal}$. Results reported here indicate that the filtrate will have quality characteristic of sewage after some modes of tertiary treatment, in that turbidities, phosphate concentration, and bacterial content will be much lower in the product than in the effluent from activated-sludge treatment. 


\section{RECOMMENDATIONS}

1. Further experiments, simulating practical operation and including substantial water recoveries, are desirable to define more closely the optima for certain variables. The most expeditious course is to carry out simultaneous tests in parallel loops, with identical feed and conditions, except for the variable under investigation. Proceeding in this way will minimize uncertainties arising from variations with time of sewage composition. Variables which need further attention include comparison of additives (Al(III) vs $\mathrm{Fe}$ (III); $\mathrm{Fe}$ (III) introduced as different salts; $\mathrm{CaO} \underline{\mathrm{vs}} \mathrm{NaOH}$ in neutralization); concentration of additive; $\mathrm{pH}$ of pretreatment and of filtration, the latter particularly with PAC; and amount of filteraid used in precoating.

2. More extensive exploration of filtration at low circulation velocities is needed.

3. A lillited number of critical tests should be carried out on sewage containing appreciable inputs from industries.

4. Modules suitable for practical systems should be designed, constructed, and tested.

5. Planning should be started for a demonstration. The most effective course would appear to be locating in our vicinity a small sewage plant presently treating only by primary settling but planning in the near future to add secondary. A cross-flow filtration system would be constructed to process the fulliprimary output, so that the feasibility of recycle of concentrated reject to the influent of the settler could be determined. An alternative next step in development might be a package plant designed for operation where space is limited (e.g., shipboard).

6. The usefulness of cross-flow filtration as an element in treatment of industrial wastes shuuld be evaluated. Jevelopments of.specific schemes for individual feeds will be required. 
INTRODUCTION

Biological methods have dominated the treatment of municipal sewage when it is carried beyond the usual primary settling stage. In spite of the widespread further processing by aerobic activated sludge or trickling filter methods, aimed at converting organic material into settleable sludge, there are deficiencies in these usual secondary methods which have kept interest alive in other approaches as supplements or alternatives. Supplementary treatments (frequently referred to as tertiary) would be aimed at improving the effluent from biological secondary processes, e.g., removal of more oxygen-demanding constituents by treatment with activated carbon, removal of phosphates by ferric or aluminum addition, or removal of ammonia by addition of lime and sparging.

Some of these tertiary methods are also under test for application directly to the primary effluent, or even raw sewage, as alternatives to conventional secondary treatment--addition of activated carbon or hydrolyzable salts, for example. The objective is to improve effluent quality, and perhaps more important, to gain reliability. Microorganisms on which aerobic treatment depends can be seriously upset by substances intermittently present in a sewage system or by flow of excessive. volume through the plant, and the restoration of their activity to give adequate treatment can take undesirably long times.

After treatment with hydrolyzable salts or with activated carbon, if, contrary to usual practice, it is introduced in powdered form, the bulk of the water still has to be separated from additives and impurities. Frequently settling is used, sometimes followed by filtration. ${ }^{1,2}$ Settling may not always be satisfactory. From tests ${ }^{3}$ at Mentor, Ohio, of additions of ferrous-containing pickle liquor with lime neutralization, for example, it was concluded that filtration might be required, since plant effluents 
were contaminated with about $10 \mathrm{milligram} / \mathrm{liter}(\mathrm{mg} / \mathrm{l}$ ) iron. In similar experiments at Milwaukee ${ }^{4,5}$ in which $\mathrm{Fe}$ (II) additions were in the range $8-15 \mathrm{mg} / \mathrm{l}$, rather than the $30-50 \mathrm{mg} / \ell$ used in Mentor, effluent contained typically one to two $\mathrm{mg} / \ell \mathrm{Fe}$, only a small fraction of which was reported as "soluble;" total phosphorus (reported by them as phosphorus P, rather than phosphate used in this report) in the effluent was in the range $0.5-1 \mathrm{mg} / \mathrm{l}$ (average 0.7 ). Since only about half of this was reported as "soluble," more efficient separation of solids should have enabled meeting the target of $0.5 \mathrm{mg} / \mathrm{l} \mathrm{P}$. Total effluent phosphorus was reduced only by half from what it was without iron addition. In Waukegan, Illinois, pickling liquor additions to the secondary stage in amounts corresponding to a 1.9 mole iron per mole $P$ in the primary effluent resulted in average $P$ in secondary effluent of $1.4 \mathrm{mg} / \ell$; polymer addition and/or filtration were felt necessary for consistently higher removals. 6

Utilization of activated carbon in powdered form has many potential advantages over granular--lower cost/lb, faster kinetics (smaller particles), for example--but its use also requires efficient solids-liquid separation. In a 545 meter $^{3} /$ day $\left(\mathrm{m}^{3} / \mathrm{d}\right)$ (100 gallons/minute (gpm)), 2-year study at Salt Lake City, ${ }^{7,8}$ coarse screened and comminuted raw sewage was successively treated with $\mathrm{Al}$ (III) or Fe(III) salts and lime to remove phosphate, then contacted with powdered activated carbon (PAC) in one or two stages, settled, and $\dot{f} 1$ nally filtered through a coal-sand bed. Regeneration of the carbon was also tested. The filtration generally reduced suspended solids (effluents 1 to $3 \mathrm{mg} / \ell$ ) and turbidities (effluents 1 to 5 JTU) by a factor of 2 to 3 and usually effected some reduction of total organic carbon (TOC), chemical oxygen demand (COD), and biological oxygen demand (BOD). Removal increased with increased carbon doses. Typically, COD of the effluent was about $10 \mathrm{mg} / \ell$ when about $350 \mathrm{mg} / \ell$ of PAC was used and feed COD was about 35 to $75 \mathrm{mg} / \ell$.

A somewhat similar 2-stage countercurrent scheme was tested at up to $110 \mathrm{~m}^{3} / \mathrm{d}$ (20 gpm) in Tucson, Arizona, the main difference being absence of phosphate removal in a separate step, though alum was added to aid solids-liquid separation. Effluents were typically well below $10 \mathrm{mg} / 2$ in $T O C$, and the final filtration step did not seem to improve product substantially over the second carbon step, except that turbidities of 
filtered effluent were substantially lower. Reduction of TOC was from $80 \%$ at $100 \mathrm{mg} / \mathrm{l}$ PAC to $90 \%$ for 250 .

Tests were carried out in Albany, N. Y., at ca. $380 \mathrm{~m}^{3} / \mathrm{d}(100,000$

gpd) 1 leve $1^{10}$ on municipal sanitary sewage, sometimes combined with storm drainage. After treatment with powdered carbon in a pipe reactor, solidsliquid separation was by a tube settler, ${ }^{11}$ followed in some cases by a tri-media filter. The effluent contained on the average $17 \mathrm{mg} / \ell$ BOD with a turbidity of 0.6 Jackson turbity units (JTU).

Numerous other studies have indicated that filtration improves removal of impurities. In tests of physical-chemical treatment, including lime addition, at Washington, D. C., ${ }^{12}$ the average suspended solids obtained over a year and a half operation was reduced from about $20 \mathrm{mg} / \ell$ in the clarified effluent to about $5 \mathrm{mg} / \mathrm{l}$ by dual-media filtration; corresponding reduction for phosphorus (as $\mathrm{P}$ ) was from 0.3 to $0.2 \mathrm{mg} / \mathrm{l}$. Even more pronounced differences between clarified and filtered water were found in alum-treated activated sludge effluent at the same station. ${ }^{13}$ observations were similar with alum-treated, trickling-filter effluent in Richardson, Texas. ${ }^{14}$ Filtration steps in treatment of waste-water in Contra Costa County, California, also improved acceptability of the effluent for industrial reuse. 15

The filtrations ut1lized for solids-liquids separations in the references cited so far have operated with the flow of the solution being filtered only in the direction perpendicular to the filtering surface. The filters attain typically extremely high rates at low pressure drops by arranging a coarse filter over a somewhat finer layer or layers, the overall looseness of the system being indicated by the appreciable turbidities and suspended solids in the filtrates. Material removed accumulates in the filter and is removed periodically by backwashing. An alternative mode, $16,17,18$ which has been called "cross-flow filtration, ${ }^{18}$ is analogous to that used in hyperfiltration (reverse osmosis). The solution is pumped parallel to the filtering surface (or relative movement of solution and surface is attained in some other way; for example, by mounting the filter on a rotor, in a variation referred to as "axial filtration"19,20). The circulation will tend to slow the thickening of flux-limiting filter cake, and one ends up with 
the bulk of the water purified by passage through the filter, and a relatively small volume containing the concentrated removed substances. While the approach does not obviate the necessity of periodic backwashes or other regeneration procedures, it allows use of a relatively tight filtering surface or filter cake, efficient in removal, and attainment of higher filtering areas per unit volume than in many standard configurations, to balance against lower production rates per square foot and energy required for pumping.

There appears to have been little done that would allow evaluation of cross-flow in application to sewage treatment. Perhaps the closest work involved cell-mounted commercial ultrafiltration membranes in bench-scale operation for dewatering powdered carbon slurries. ${ }^{21}$ This report describes exploratory investigations of the use of cross-flow filtration with tubular filter elements to primary and secondary effluents treated with hydrolyzable salts and/or powdered activated carbon. The study started in 1970 and has continued intermittently up to Spring 1975. 
EQUIPMENT AND EXPERIMENTAL METHODS

\section{CROSS-FLOW FILTRATION EQUIPMENT}

The essential feature of the approach is a configuration allowing filtration under conditions of relative movement of the fluid being filtered and the filtering surface. In the work reported here, this was accomplished by pumping the solution through the inside of a tubular filter, or through the annulus between the outside of a tubular filter and outer pressure jacket.

The bulk of the study was carried out in a unit located at the oak Ridge East Municipal Sewage Plant. The installation has been modified and amplified from time to time. The main elements are shown schematically in Fig. 1.

The units for addition of hydrolyzable salts and acid and base for the desired $\mathrm{pH}$ cycle are housed in a $2.3 \times 3.7 \mathrm{~m}\left(71 / 2^{\prime} \times 12^{\prime}\right)$ van. The effluent from primary or secondary treatment is pumped into Tank I when called for by level controls, and Fe(II), Fe(III), or Al(III) salts plus acid to the appropriate $\mathrm{pH}$ are metered in. In reporting results, $\mathrm{mg} / \ell$ of $\mathrm{Fe}$ (III) or $\mathrm{Al}$ (III) refer to the amount added to incoming primary effluent, rather than the amount in the circulating solution being filtered, in which the content will increase as filtrate is removed. Powdered activated carbon can be added in addition or alternatively. Air sparging removes $\mathrm{CO}_{2}$, oxidizes $\mathrm{Fe}$ (II) to $\mathrm{Fe}$ (III), and helps mixing. This solution moves to Tank II on call, and base is added to bring it to the operating $\mathrm{pH}$. Air is passed through to complete oxidation to $\mathrm{Fe}$ (III).

Level controls in the feed tank III, located, along with the rest of the system, in a 2.4 by $18.3 \mathrm{~m}\left(8^{\circ} \mathrm{x} 60^{\circ}\right.$ ) trailer, activate the transfer of tank II solution into it. From the feed tank, the solution is pumped 


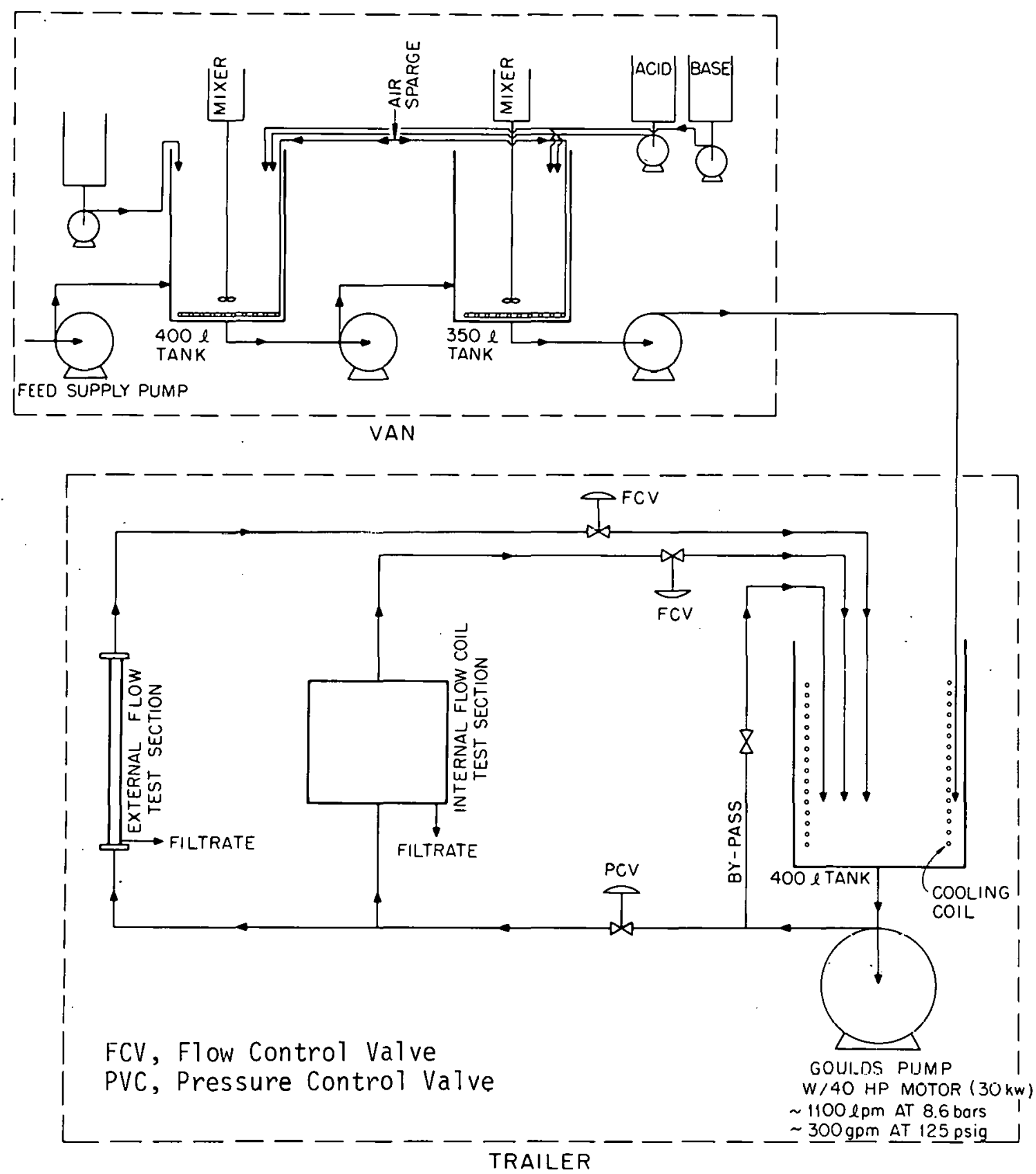

Fig. 1. Schematic of cross-flow filtration test unit.

( $\mathrm{pH}$ and level controls, valves, instrumentation for flow measurement. backwash equipment, and second-stage cross-flow loop not shown) 
through the filter test sections, pressure being maintained by passage through a let-down valve before return to the feed tank. The filtrate is only a small fraction of the solution passing through the test section and consequently all parts of the test sections see essentially identical solutions at a given time. Filtrate can be discarded, recycled to the feed tank, or transferred to the feed tank of a second loop for tests of second-stage operation. A D/P cell, connected with a Foxboro recorder, monitors the pressure drop across each test section, and allows determination of the circulation velocity.

Two cross-flow loops are located in the trailer; one has provision for two test sections in parallel, and is equipped with a 1135 liters/ minute ( $\ell / \mathrm{min}$ ) (300 gallons (U.S.)/minute (gpm)) at 862,000 Newtons/square meter $\left(\mathrm{N} / \mathrm{m}^{2}\right)$ (125 pounds per square inch, measured by gauge (psi)) Goulds centrifugal circulation pump; the other has provision for 5 parallel test sections and is equipped with a $950 \mathrm{l} / \mathrm{min}(250 \mathrm{gpm})$ at $862,000 \mathrm{~N} / \mathrm{m}^{2}$ (125 psi) Goulds pump. Originally the pumps were used with packed seals, but rapid wear, particularly in runs with powdered carbon, led us to substitute mechanical seals. Metal cooling coils in the feed tanks remove heat generated in circulation of the solution.

Tesl 3eclions

Several different types of test sections have been used. Figure 2 is a picture of a typical unit not completely assembled. A $2.54 \mathrm{~cm}$ (1") diameter polyester-nylon fire-hose jacket, ${ }^{18}$ (manufactured by Fabric Fire Hose Co., Sandy Hook, Conn.) is slipped over a perforated stainless steel tube. A transparent plastic jacket defines the outer wall of the annulus. Figure 3 shows a similar unit installed in a laboratory cross-flow loop. To the right is a test section in which feed is circulated on the inside. Outside flow with supported hoses allows backwashing; with inside flow, other regeneration methods must be used. Figure 4 shows some larger, outside-flow configurations, operating in one of the loops in the mobile unit. The test section in the center of the picture has four tubes in parallel, which give a total of about $0.37 \mathrm{~m}^{2}$ (four square feet) of membrane area. 


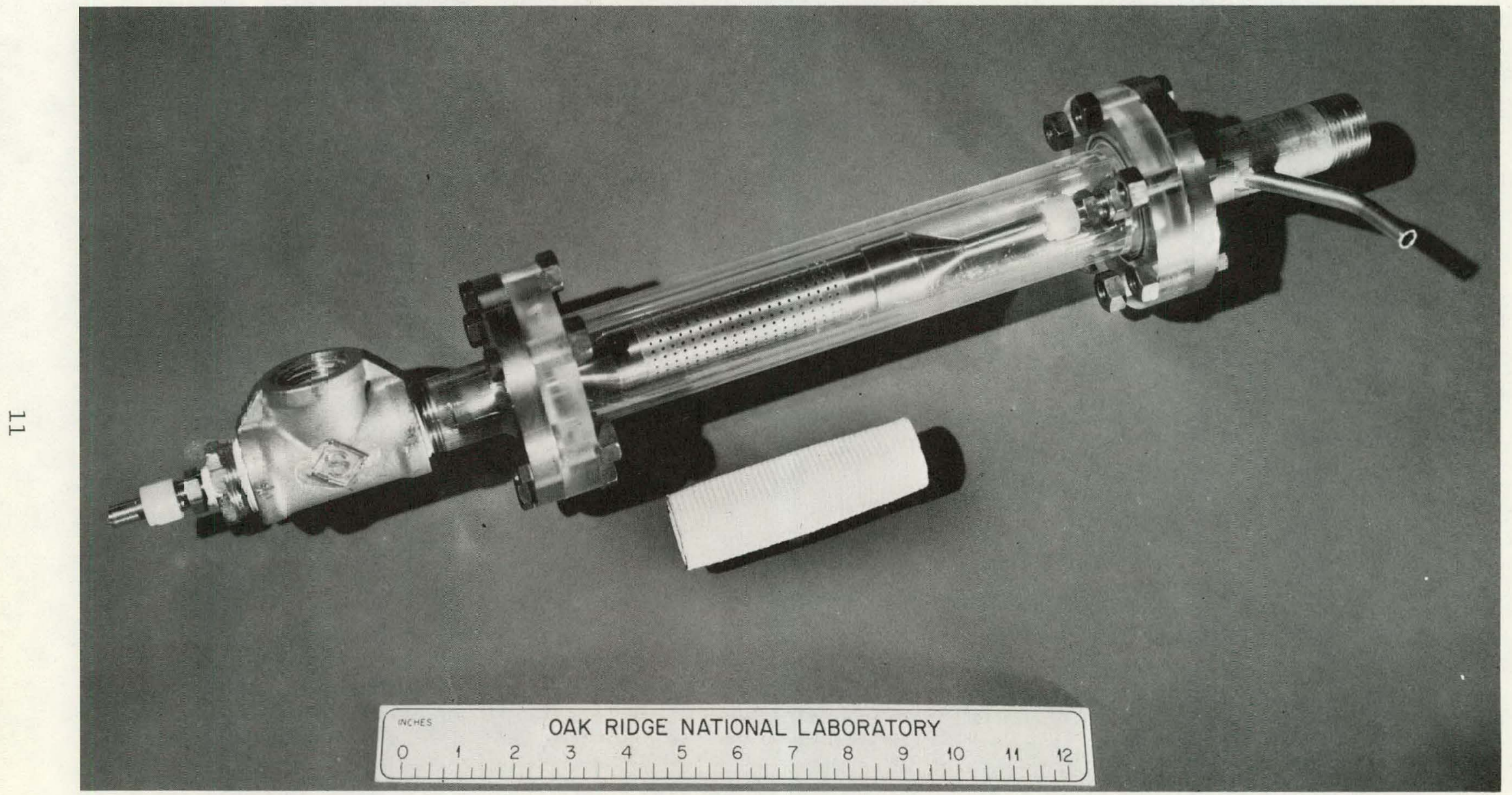

Fig. 2. Cross-flow filtration element. 


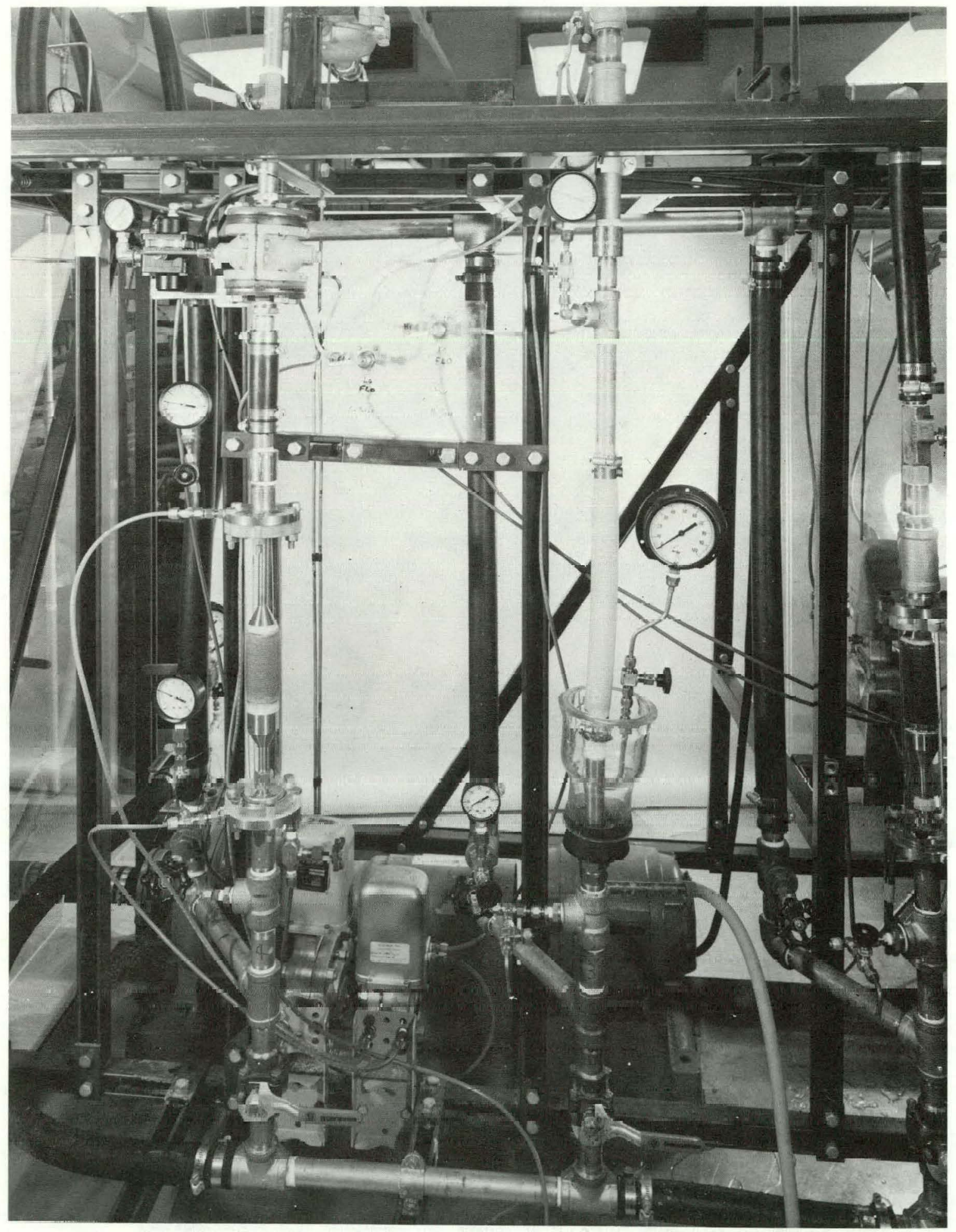

Fig. 3. Cross-flow filtration unit installed in laboratory loop. (Left: external flow of pressurized solution. Right: internal flow.) 


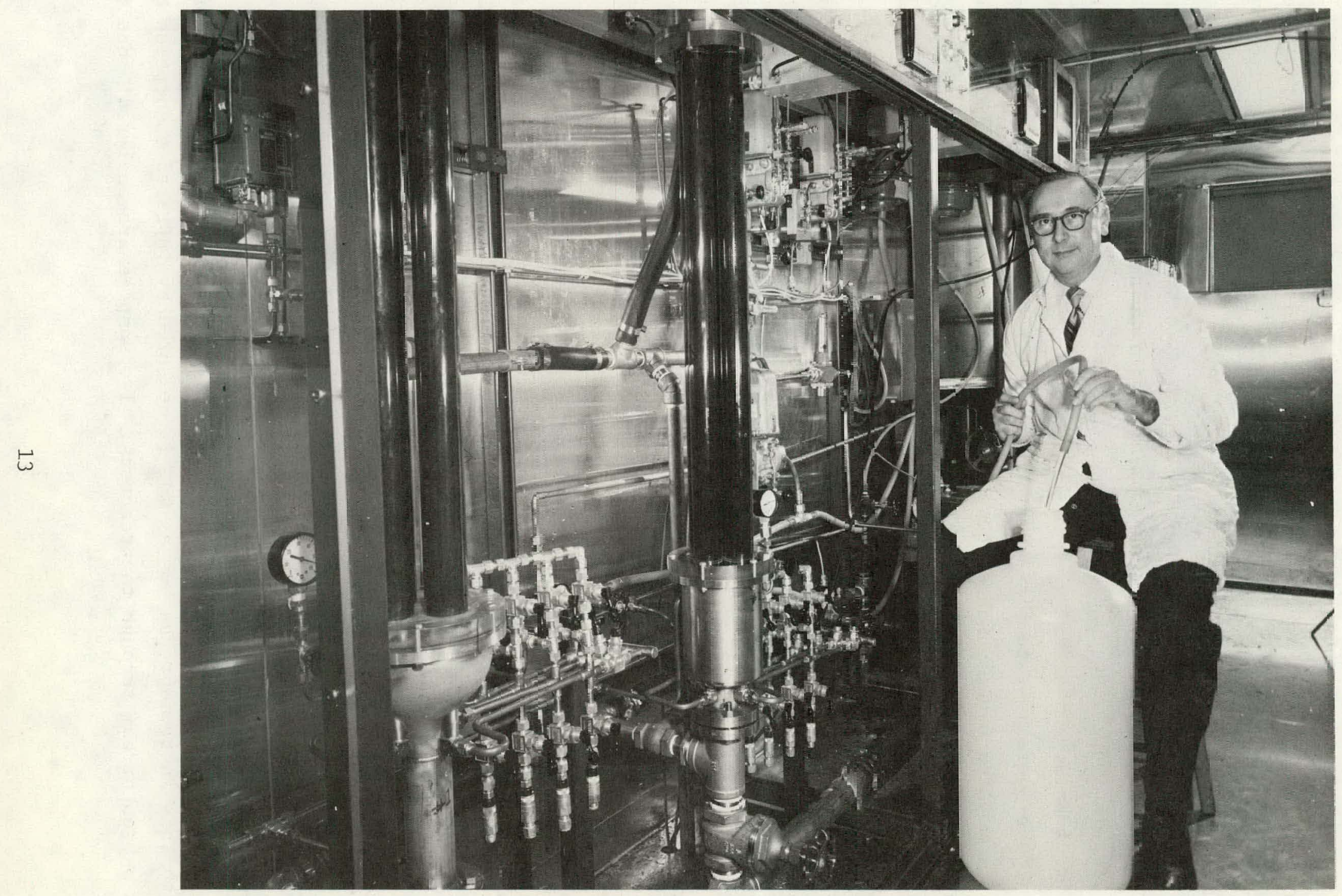

Fig. 4. Multielement external flow module installed in mobile unit. 
An inside-flow unit of comparable filtering area is diagramed in Fig. 5. A coil of about $5.5 \mathrm{~m}\left(18^{\prime}\right)$ of fire-hose jacket is wrapped around a thin cylinder of sheet metal in a 114 \& (30-gallon) stainless-steel barrel. In contrast to the other units, there is a very substantial drop in pressure through the unit-- $225,000 \mathrm{~N} / \mathrm{m}^{2}$ (32 psi) at $4.6 \mathrm{~m} / \mathrm{sec}$ (15 ft/sec) circulation velocity, for example.

Filtering surfaces are not restricted to fire hose jackets. Screens from 20 to 400 mesh, with a precoat of a fibrous asbestos or cellulosic filteraid, were also used. Precoats also appeared advantageous with firehose jackets.

The overall system is a test unit, rather than a pilot plant. Production rates usually ranged between a hundred and a thousand gallons per day. On the basis of results obtained with the mobile unit, a nominal $378 \mathrm{~m}^{3} / \mathrm{d}(10,000 \mathrm{gpd})$ pilot plant ${ }^{22,23}$ was constructed at the Oak Ridge National Laboratory sewage treatment plant. Although work done with it is outside the scope of this program, tests of some operating conditions were much simpler with the unit, and some results are reported here. The filter surfaces were nominal $7.6 \mathrm{~cm}$ diameter ( 3 " I.D.) fire-hose jackets supported on the inside by perforated stainless steel tubes, with feed in the annulus between the jackets and hose of $10.2 \mathrm{~cm}$ (4") stainless steel pipe. Ten $2.44 \mathrm{~m}\left(8-\mathrm{ft}\right.$ ) units (about $0.65 \mathrm{~m}^{2}\left(7 \mathrm{ft}^{2}\right)$ each) are connected in series, with valving and bypassing allowing successive pairs to be included or excluded from the circulating stream.

None of these configurations are projected for actual sewage processing. Rather, they are experimental arrays, with defined flow patterns, convenient for studying the effect of variables of performances.

\section{ANALYSES}

Evaluation of treatment was primarily based on total organic carbon (TOC), phosphate, and iron in the filtrate. Turbidity (as measured by a Hach 2100 Hach turbidimeter) was also monitored.

Total organic carbon (TOC) was measured with a Beckman 915 analyzer. With this instrument, carbon as $\mathrm{CO}_{2}$ is measured by infrared absorption of an oxygen stream through the reactors. Two samples are analyzed: one is 


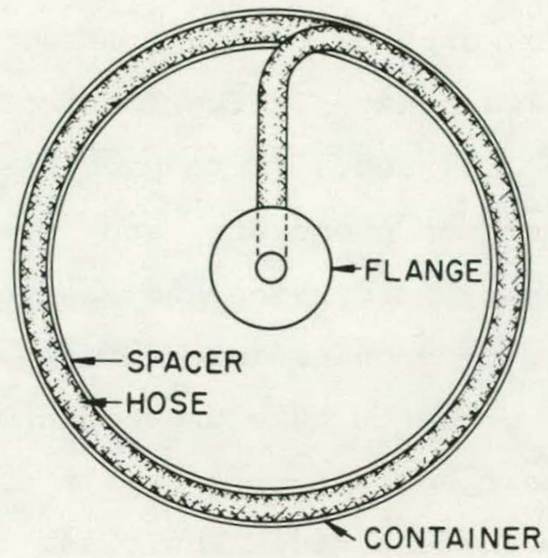

TOP

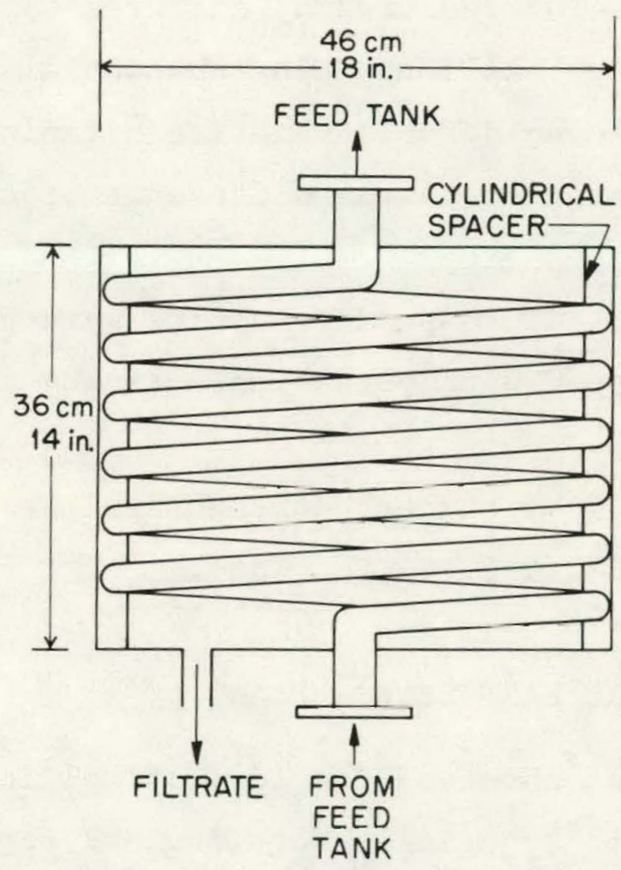

SIDE

Fig. 5. Cross-flow filtration test module, internal flow through fire hose jacket. 
injected into a phosphoric acid reactor, which displaces carbon dioxide from inorganic carbonate species; the other is a high-temperature catalytic reactor, which oxidizes organic carbon components to $\mathrm{CO}_{2}$, as well as decomposing inorganic carbonates. The TOC is the difference in the carbon determined in the two analyses. There have been questions raised about the accuracy of this difference procedure, and some have recommended eliminating the inorganic step by acidifying and gas purging to remove inorganic species, before injecting samples into the organic reactor. However, if volatile organics are present, this procedure would lead to incorrect estimates of the organic content. In Fig. 6 are plotted some results with primary effluent from the Oak Ridge Municipal plant. These show a discrepancy between TOC obtained by difference and TOC measured directly on acidified, air-sparged samples. However, similar discrepancies are observed with samples (TOC measured by difference) air sparged at approximately neutral $\mathrm{pH}$, which still contain substantial inorganic carbon. It appears that there is considerable volatile organic carbon present, and we therefore report analyses by the difference procedure specified for the instruments.

In analysis of total phosphate, samples were pretreated with persulfate, and color developed with potassium antimony tartrate and ascorbic acid (Ref. 24, p. 236).

Iron analyses were by the orthophenanthroline method, after pretreatment with hydroxylamine (Ref. 24, p. 156).

\section{THE OAK RIDGE MUNICIPAL EAST SEWAGE PLANT}

The facility is of about $5700 \mathrm{~m}^{3} / \mathrm{d}$ ( 1.5 million gallons per day) capacity. Treatment is by primary settling and activated sludge secondary with chlorination of effluent and anaerobic digestion of sludge. The plant is one of two handling the wastes of the city, essentially a bedroom community of approximately 28,000 population. High flows occur during heavy rains. Sewage during these periods is of low organic content.

A summary (Fig.7) of characteristics of the primary effluent, measured over a year, is reprinted from an earlier report. 25 Some measurements taken during the course of this work are presented in Figs. 6 and 8 . 


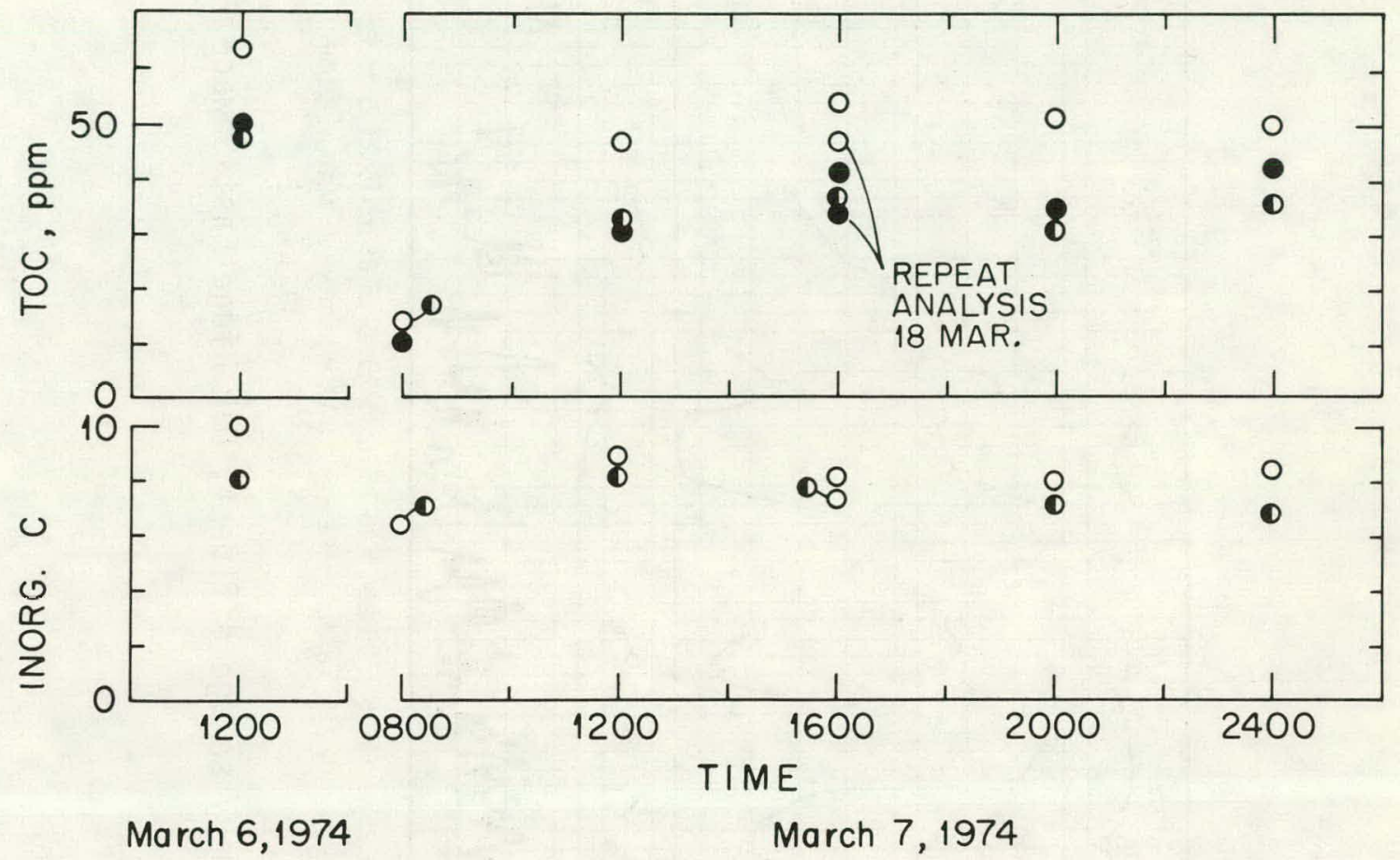

Fig. 6. Comparison of TOC analyses of primary sewage.

- Difference between total and

Analyzed inorganic carbon, as received

- Difference between total and 11-15 Mar. inorganic carbon, air-sparged, 15 Mar. neutral $\mathrm{pH}$

- Air-sparged after acidification (all inorganic carbons < $1 \mathrm{ppm}$ ) 


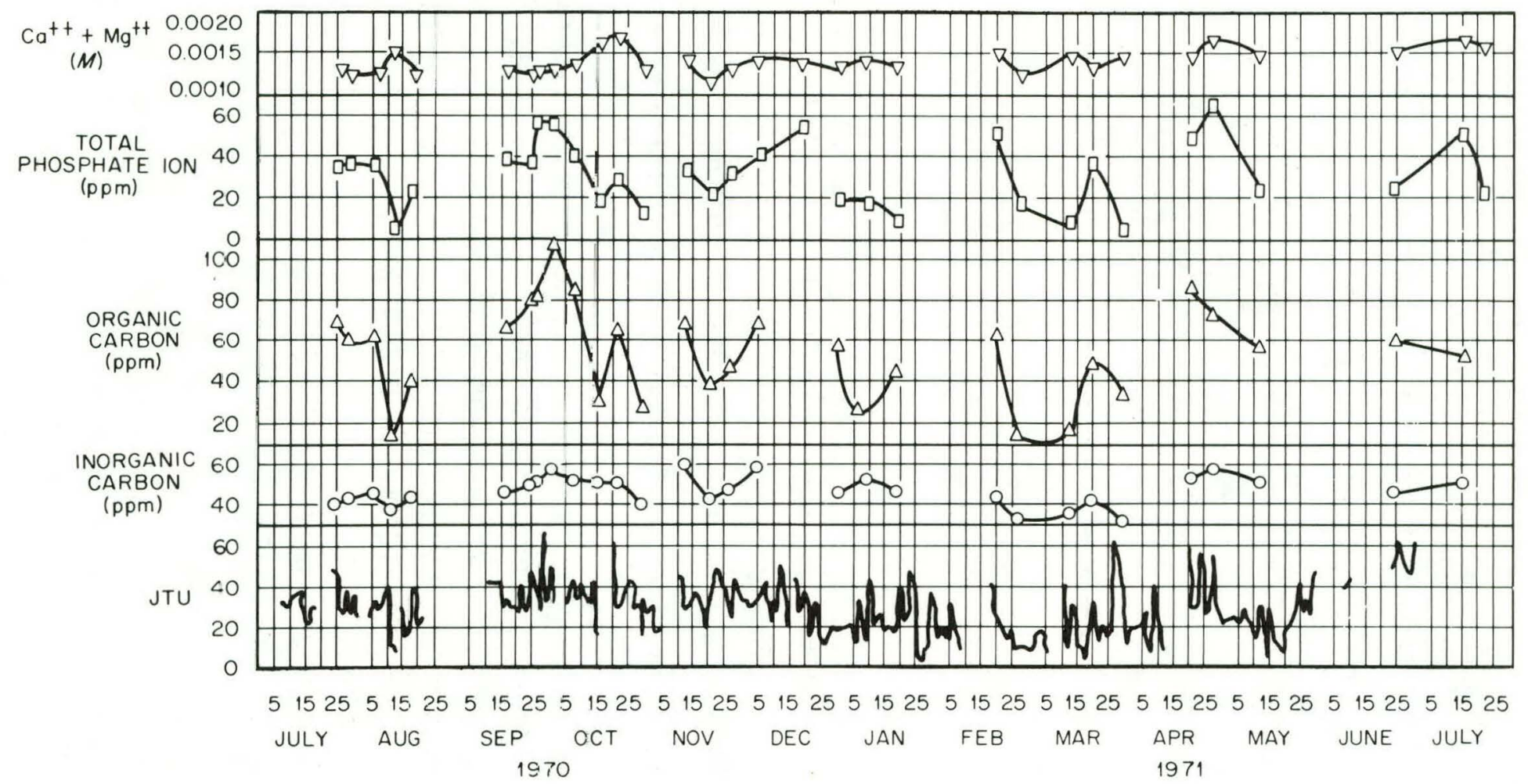

Fig. 7. Variation of constituents in primary sewage effluent, Oak Ridge East Sewage Plant. 


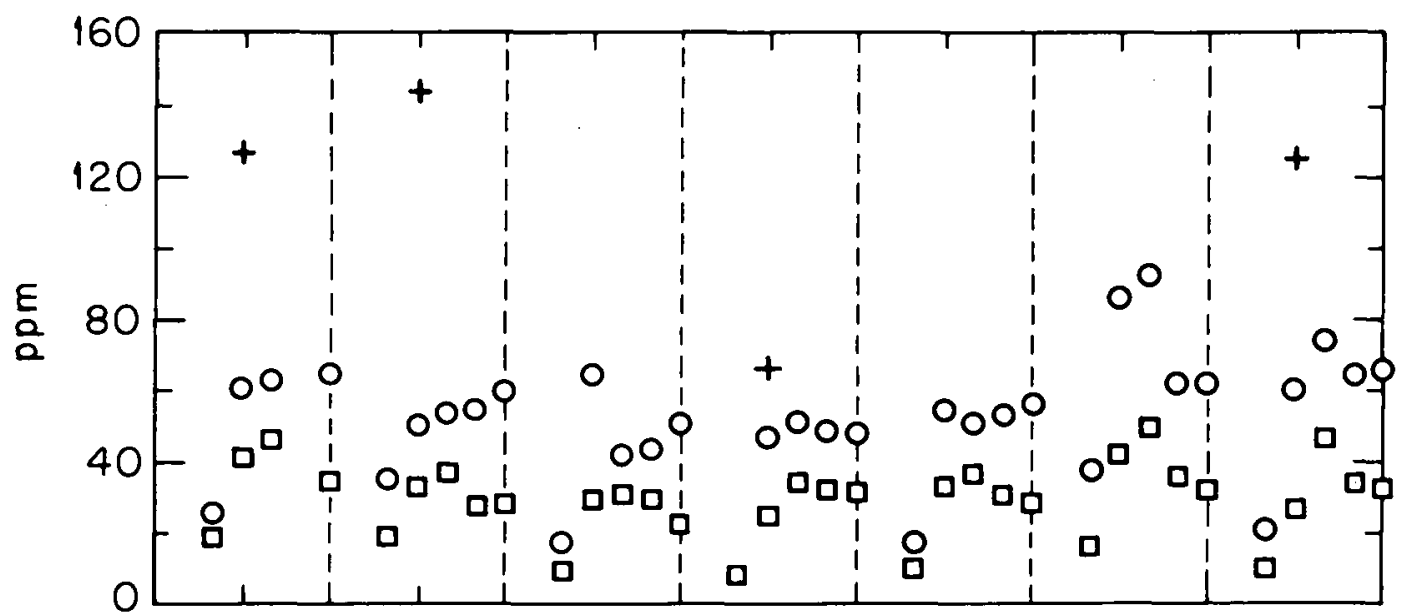

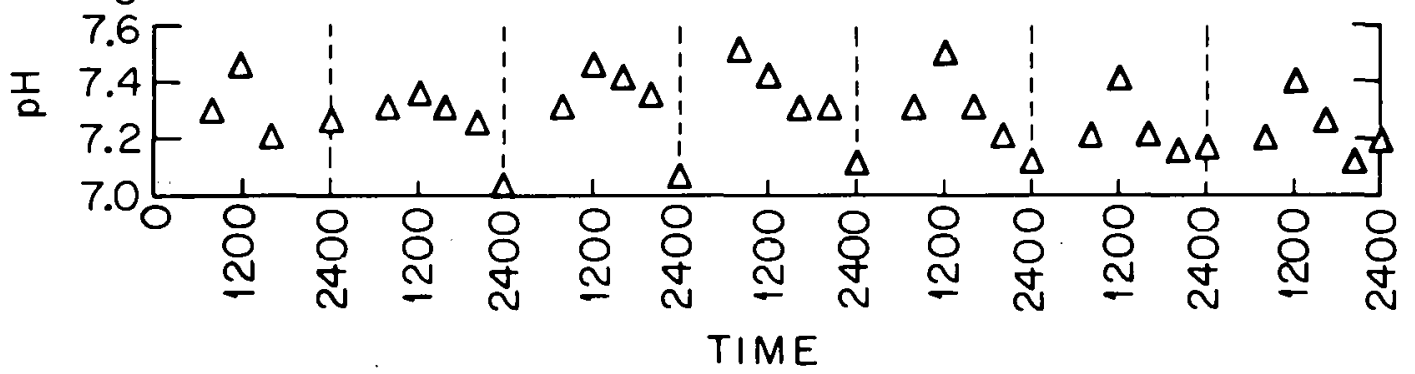

\begin{tabular}{l|l|l|l|l|l|l|l|} 
DAY & MON. & TUES. & WED. & THUR. & FRI. & SAT. & SUN. \\
WEATHER & CLEAR & RAIN & RAIN & CLOUDY & CLEAR & CLEAR & CLOUDY
\end{tabular}

Fig. 8. Primary sewage analyses, Oak Ridge East Sewage Plant.

(March $4=10,1974)$ 
Values of BOD in the figure were provided by the staff of the sewage plant.

The composition of sewage is highly variable and consequently only limited confidence can be placed in results of a single experiment. This situation makes more difficult determination of the effects of variations in experimental conditions and the optimization of processes. In the Oak Ridge case, besides gross differences in feed composition after rainfall, organic carbon contents were high when septic tank sludge or digestor supernate were discharged into the plant. We were not always aware of the latter occurrences.

THE OAK RIDGE NATIONAL LABORATORY PLANT

The Oak Ridge National Laboratory plant, at the time of the pilotplant tests reported here, was of approximately $570 \mathrm{~m}^{3} / \mathrm{d}(150,000 \mathrm{gpd})$ capacity. Treatment was of sanitary wastes generated in the $\mathrm{x}-10$ area and was limited to primary settling. The effluent.during working huurs was comparable in TOC to that from primary treatment of the municipal plant, but TOC was much lower at night and on weekends. 
In this study, over two hundred and fifty runs, typically of about 24 hours duration, ware made at the Oak Ridge municipal plant, plus some sixty preliminary laboratory tests. It is not feasible to present a detailed account of all experiments, even if operating difficulties and errors in execution had not so flawed many as to compromise their value. Consequently, the report will organize results to illustrate the effect of important parameters. Among the variables of interest for which some information is presented are:

- Feed--primary, secondary effluent, or other.

- Cross-flow velocity.

- Pressure.

- Performance as a function of water recovery (fraction of water removed as filtrate).

- Temperature

- Additives--Fe(II) or Fe(III), or Al(III) salts; powdered activated carbon (PAC); other chemicals.

- $\mathrm{pH}$.

- Type of filtering surface.

- Precoating of filtering surface.

- Efficacy of backwashing or other regeneration procedures.

Because feedstock varied and because the system har many variables, nngluoions cuncerning optimum performance and conditions are tentative. However, our experienres do indicate the promise of the approach, and the situations in which it may be useful.

Before discussing in detail effects of additives, we shall present results illustrating effects of operational variables. 
OPERATION VARIABLES

Effect of Cross-Flow Velocity

Pumping solutions parallel to the filtering surface has been shown to increase fluxes in filtration of various materials. ${ }^{18}$ Cross flow has a similar effect with sewage. We have previously reported a laboratory experiment in which a single unit was tested without circulation and, after an intervening backwash, with circulation; flux decline was much less sharp with cross flow than without (Fig. 12 of Ref. 26). Fig. 9 summarizes a similar test carried out at the sewage plant, in which two external flow units were exposed simultaneously, one with no cross flow and the other with circulation at $4.6 \mathrm{~m} / \mathrm{sec}(15 \mathrm{ft} / \mathrm{sec})$. Both units were precoated with a fibrous filteraid prior to exposure to ferric-treated primary sewage effluent, and the fluxes with water at the end of pretreatment were essentially the same. Flux decline was much more rapid without cross flow. Filtrate quality was not very different--organic carbon was 10 to $15 \mathrm{mg} / \mathrm{l}$ from both units during the first hours of operation and about 5 after overnight; phosphate averaged $0.4 \mathrm{mg} / \ell$, and was in all cases less than $1 \mathrm{mg} / \mathrm{l}$; and iron was about $0.1 \mathrm{mg} / \ell$.

The slope of -0.5 indicated in Fig. 9 requires comment. For constant concentuation of filtprable material, if flow resistance of the filter is negligible compared to that of the cake; if a constant fraction of filcerable material contained in solution passing through the filter is deposited in the cake; and if there are not changes in intrinsic permeability of the cake, a slope of -0.5 is predicted for $\log$ flux vs $\log$ time $^{19}$ (see also Ref. 27). A slope steeper than -0.5 for constant water recovery, as in the no-cross-flow case of Fig. 9, probably indicates a change in the cake with time, perhaps from compaction or from change in the particle size from attrition in pumping; such a change may account for the less dramatic effect of cross flow than in Fig. 12, Ref. 26. In many subsequent figures, a slope of -0.5 is indicated as a reference; it is not completely appropriate when water recovery is not constant (i.e., the concentration of the solution being filtered increases with time). Fig. 10, a picture of test sections after operation for $31 / 2$ hours, illustrates qualitatively that fouling is less at $4.6 \mathrm{~m} / \mathrm{sec}(15 \mathrm{ft} / \mathrm{sec})$ than at lower circulation velocities. 


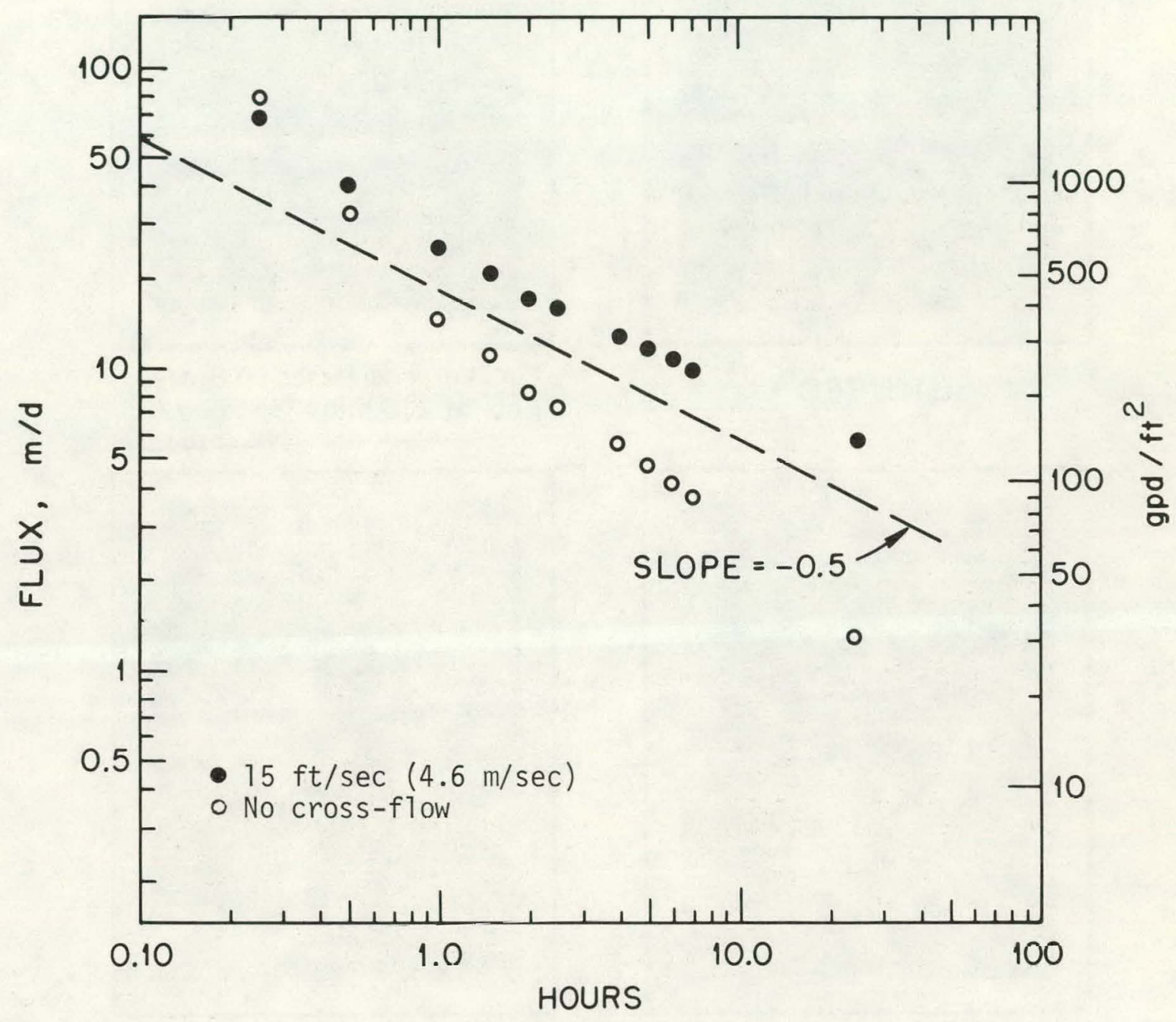

Fig. 9. Fluxes in filtration of primary sewage effluent with and without cross-flow.

(37 ppm Fe(III); $\mathrm{pH} 6.5 ; 37^{\circ} \mathrm{C}$; fire-hose jackets, 40 psi $[2.8$ bar $]$; outside) 


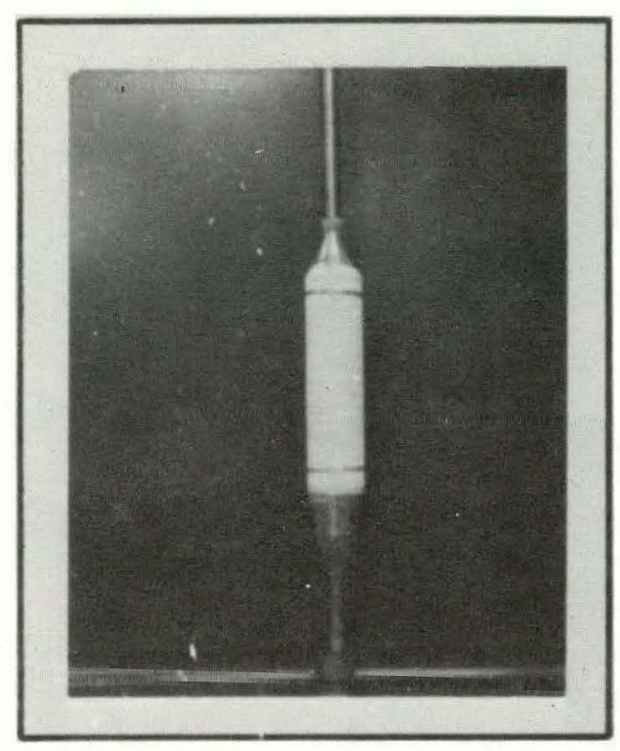

UNUSED

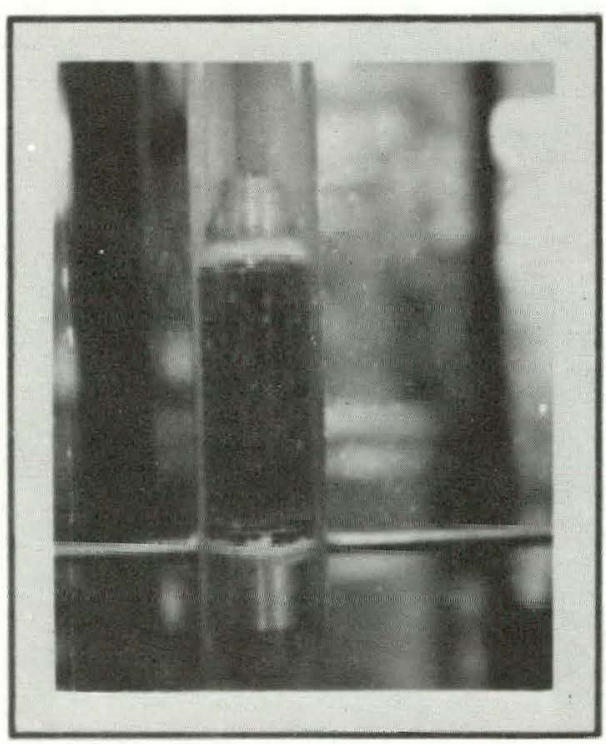

Circ. Vel. $=7.5 \mathrm{ft} / \mathrm{sec}(2.3 \mathrm{~m} / \mathrm{sec})$

Flux at $210 \mathrm{~min}=255 \mathrm{gpd} / \mathrm{ft}^{2}$

$(10.3 \mathrm{~m} / \mathrm{d})$

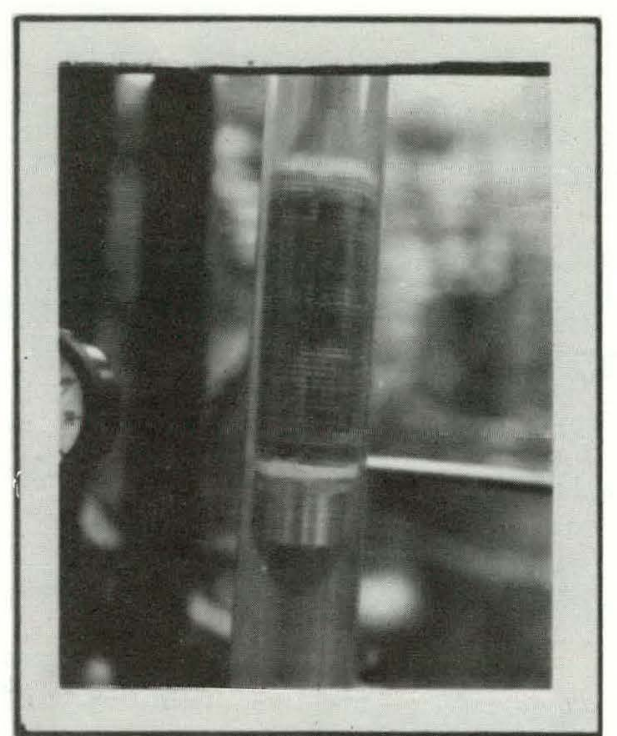

Circ. Vel. $=15 \mathrm{ft} / \mathrm{sec}(4.6 \mathrm{~m} / \mathrm{sec})$ Flux at $210 \mathrm{~min}=345 \mathrm{gpd} / \mathrm{ft}^{2}$ $(14 \mathrm{~m} / \mathrm{d})$

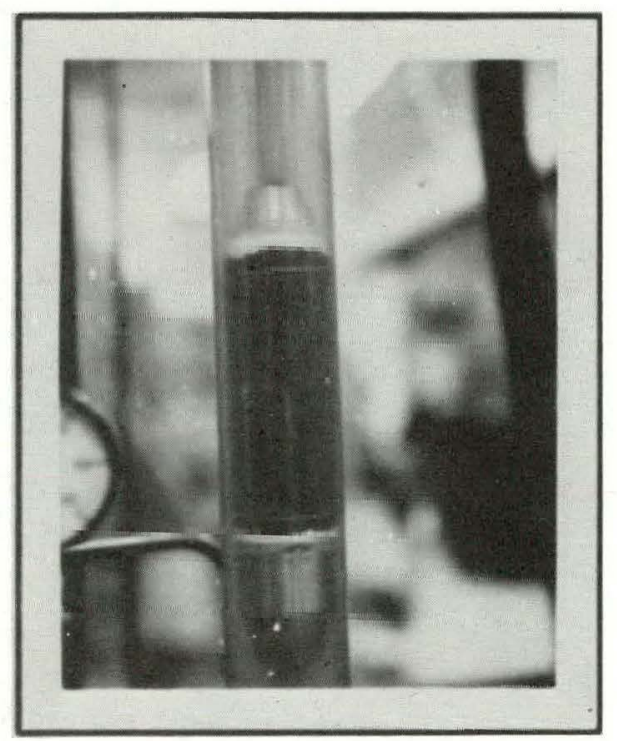

Circ. Vel. $=3.75 \mathrm{ft} / \mathrm{sec}(1.1 \mathrm{~m} / \mathrm{sec})$

Flux at $210 \mathrm{~min}=165 \mathrm{gpd} / \mathrm{ft}^{2}$

$(6.7 \mathrm{~m} / \mathrm{d})$

Fig. 10. Cross-flow filtration of primary sewage: effect of circulation velocity.

$\frac{\text { Feed }}{\text { T.O.C. } 91 \mathrm{ppm}}$
$\mathrm{PO}_{4} \equiv 40 \mathrm{ppm}$
Turbidity $55 \mathrm{JTU}$
$\mathrm{Fe}$ (III) $98 \mathrm{ppm}$
(0.00177M)

Filtrate
8 to $13 \mathrm{ppm}$
$0.6 \mathrm{ppm} \mathrm{(ave.)}$
0.88 JTU (ave.)
< $0.1 \mathrm{ppm}$ (ave.)


Figure 11 summarizes comparative laboratory tests with three different cross-flow rates. Fluxes were higher at higher circulation velocities.

Table 1 collects results for several runs in which two test sections were operated simultaneously under conditions identical except for circulation velocity. In every case, fluxes were higher at the higher circulation velocity.

It is clear from these and from other results that energy spent in pumping feed past the filtering surface effects higher fluxes. Optimum circulation velocity is determined by many factors, including energy cost, equipment cost, specific characteristics of feed, and the premium placed on conserving space.

\section{Effect of Pressure}

For a fixed flow resistance, flux should increase linearly with pressure difference across a filtering element. From many observations, some of which are documented elsewhere in this report, it has appeared that the fluxes attained in cross-flow filtration follow no such simple pattern (see, for example, Fig. 3 of Refereñce 18). Indeed, independence of pressure (so long as the filter cake has not previously been exposed to higher pressure in previous operation) seems to be a better first approximation. For example, when outside flow elements have been operated simultaneously with the inside flow unit pictured in Fig. 5, pressures vary tyoically at $4.6 \mathrm{~m} / \mathrm{sec}\left(1 \mathrm{f} \mathrm{ft} / \mathrm{sec}\right.$ ) from $275,000 \mathrm{~N} / \mathrm{ml}^{2}$ (40 psi) to $255,000 \mathrm{~N} / \mathrm{m}^{2}$ (37 psii) with the outside flow unit and from $275,000 \mathrm{~N} / \mathrm{m}^{2}$ (40 psi) to $35,000 \mathrm{~N} / \mathrm{m}^{2}$ ( $5 \mathrm{psi}$ ) over the $5.5 \mathrm{~m}$ (18 ft) length of hose in the inside flow unit. Average fluxes. for the two units usually are not greatly different, however (see, for example, Fig. 12). In some cases, flux through the inside unit has been higher, in spite of the lower average pressure of the feed in it.

The ORNL pilot plant (see Equipment and Experimental Methods) is admirably suited for testing pressure dependence; there is a large pressure drop through the system and product streams from separate modules can be Individurtity mnitored. S1nçe only a fraction of the volume passing through the system in a single pass is filtered, experimental conditions 
Table 1. EFFECT OF CROSS-FLOW VELOCITY ON. FLUX IN FILTRATION $\checkmark$ OF EFFLUENT FROM PRIMARY TREATMENT OF SEWAGE

$\left(275,000 \mathrm{~N} / \mathrm{m}^{2}\right)$

(40 psi)

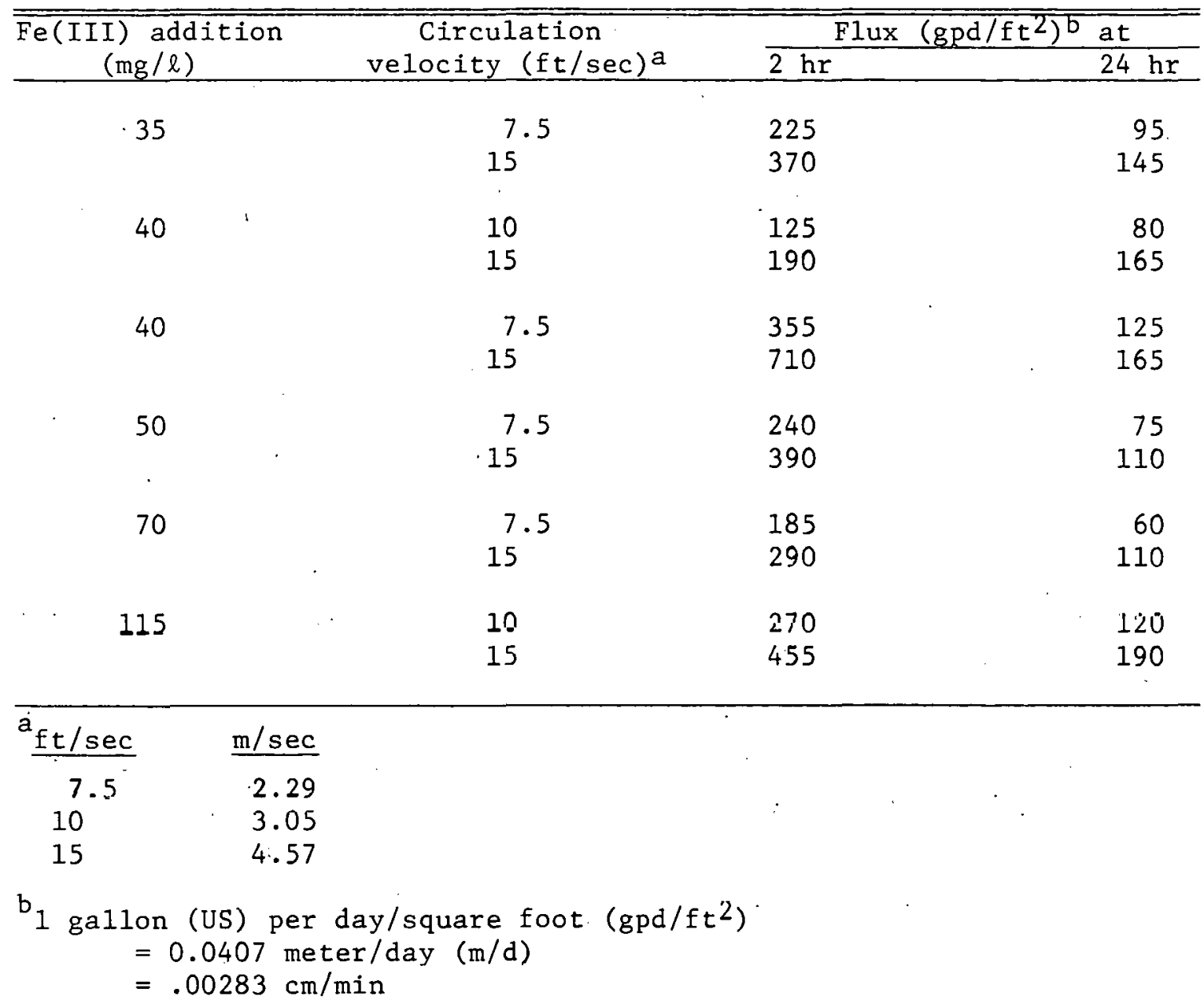




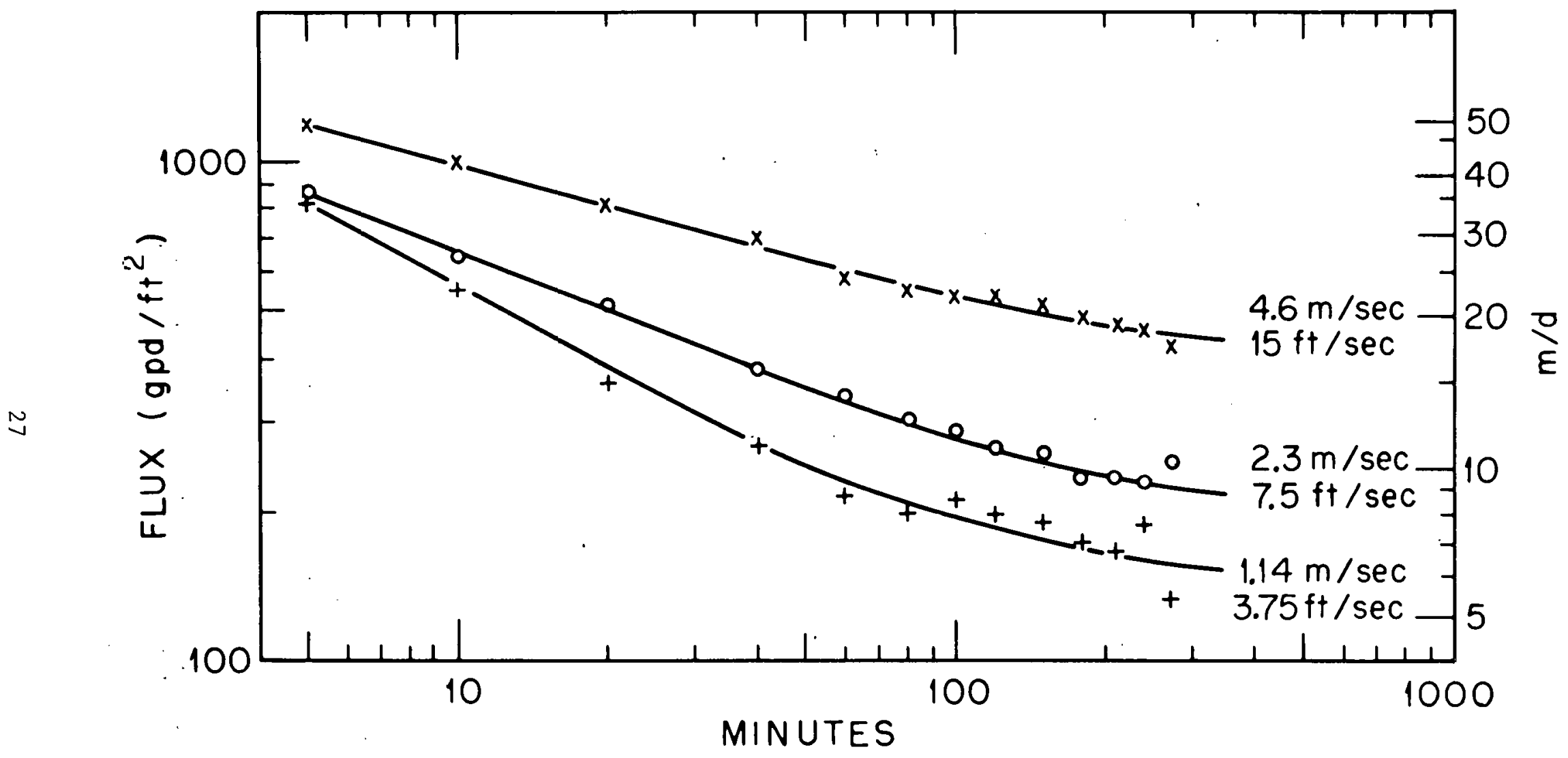

Fig. 11. Cross-flow filtration of primary sewage. $(\mathrm{Fe}(\mathrm{III}), \mathrm{ppm} / \mathrm{TOC}=1.1 ; 30 \mathrm{psi}[2.1 \mathrm{bar}])$ 
N

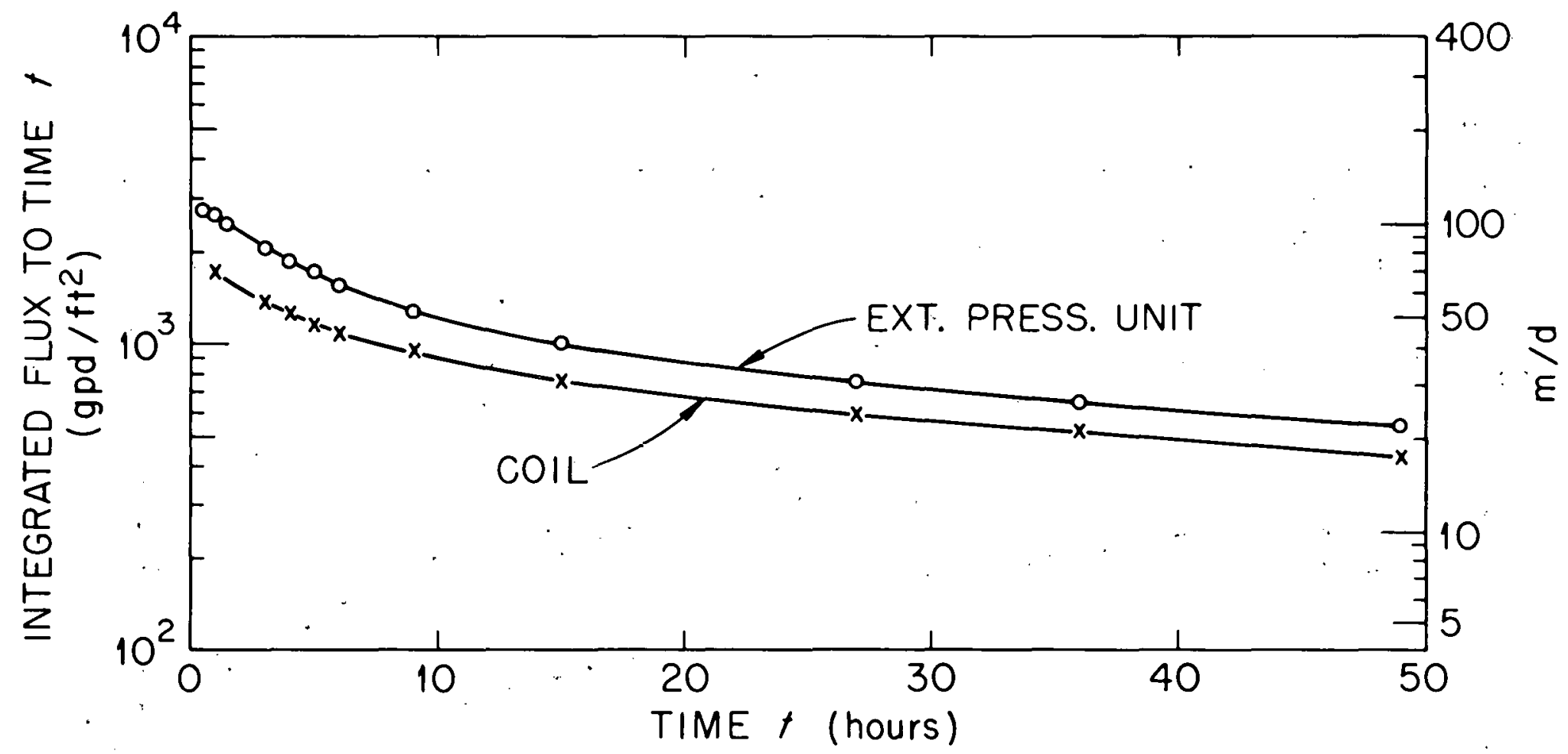

Fig. 12. Cross-flow filtration of sewage with activated carbon. (Aqua Nuchar A, Concentration $20 \mathrm{~g} / \ell, \mathrm{pH} 4$ ) 
in successive modules are essentially the same, except for average pressure. Figure 13 presents results of a test carried out with six modules on stream. $^{23}$ It can be seen that fluxes have no simple dependence on pressure, and tend to vary less with pressure with increasing time of operation .

It may be that the filter cake becomes compressed when exposed to higher pressure, though, if so, the tighter layer is not reflected in any apparent variations in product quality from successive modules. An alternative explanation is that fluxes are much higher right after startup at higher pressure and quickly build up a thicker flux-limiting cake than is deposited on the surfaces exposed to lower pressures.

The behavior is similar to that sometimes observed in ultrafiltration of proteins, in. which independence of flux with pressure is approached at higher pressure ranges of operation. The limiting flux increases with the stirring intensity. However, models currently used, based on diffusive transport of particles away from the membrane surface, do not seem adequate to explain observed fluxes. ${ }^{28}$

Pumping sòlution past filtering surfaces consumes energy. Early results have indicated that fluxes obtained in operation at low pressure and low circulation velocity, though not as high as in the range of operation of most tests reported here, might be of interest. The sharp rise in cost of energy in recent years has led us to reexamine briefly performance at low circulation velocity.

In a test at the municipal plant, two test'sections were operated simultaneously under conditions identical except for pressure and circulation velocity. One unit, in common with many experiments reported here, was at $275,000 \mathrm{~N} / \mathrm{m}^{2}(40 \mathrm{psi})$ and $4.6 \mathrm{~m} / \mathrm{sec}(15 \mathrm{ft} / \mathrm{sec})$ circulation velocity; the other was at $69,000 \mathrm{~N} / \mathrm{m}^{2}$ (10 psi) and $1.5 \mathrm{~m} / \mathrm{sec} \cdot(5 \mathrm{ft} / \mathrm{sec})$. Fluxes for the higher pressure and circulation velocity were two to three times as high (Fig. 14). An impression of the significance can be inferred from Fig. 15. The computed values of pumping energy as a function of circulation velocity and flux in the figure, taken from Ref. 29, apply strictly only to the configuration assumed, but the relative values are nevertheless informative. A flux obtained at $1.5 \mathrm{~m} / \mathrm{sec}(5 \mathrm{ft} / \mathrm{sec}$ ) would have to be over twenty times as high at $4.6 \mathrm{~m} / \mathrm{sec}(15 \mathrm{ft} / \mathrm{sec})$ for the same kwhr 


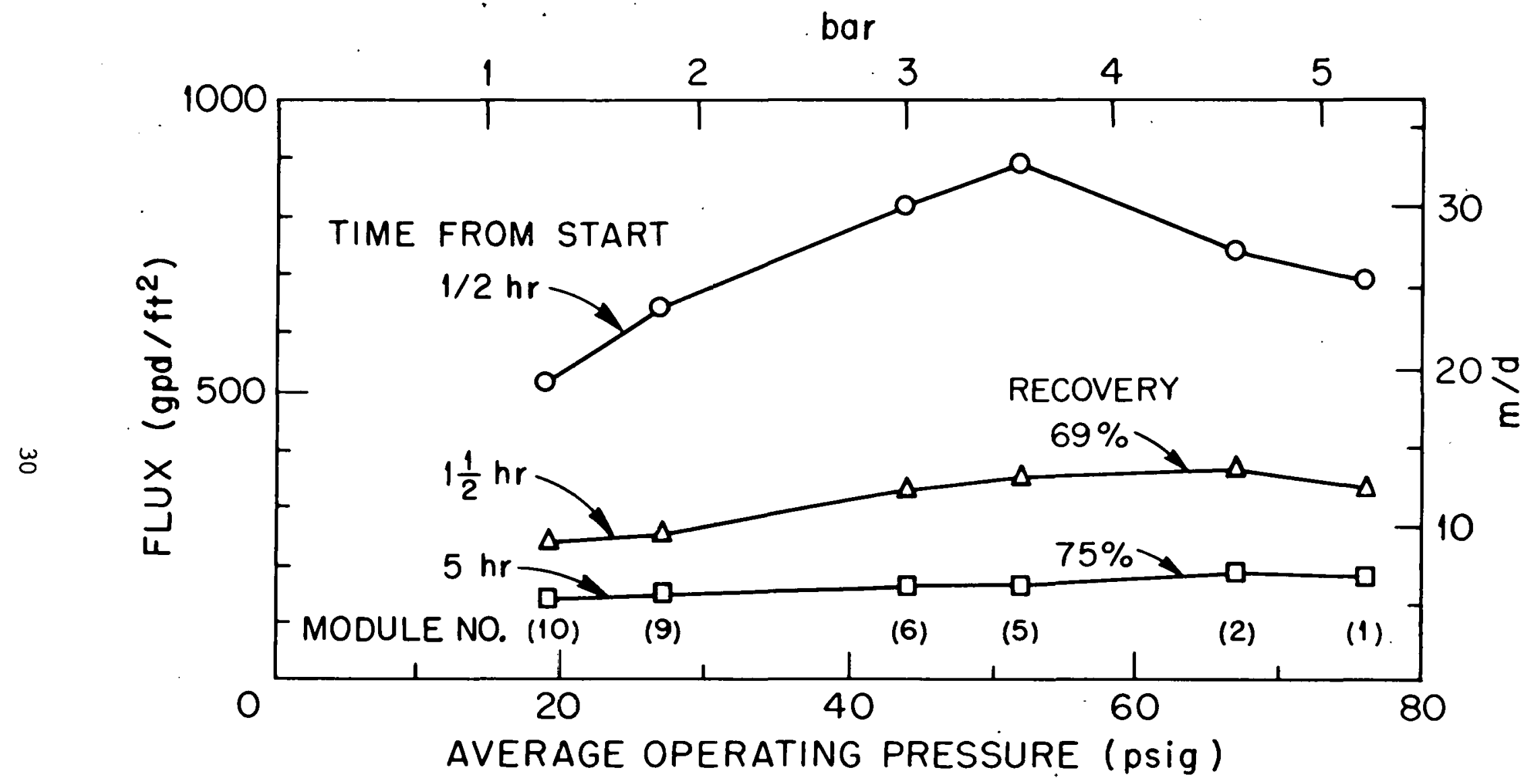

Fig. 13. Flux vs average pressure in cross-flow filtration of ORNL primary sewage (Ref. 23).

$(15 \mathrm{ft} / \mathrm{sec}[4.6 \mathrm{~m} / \mathrm{sec}])$ 


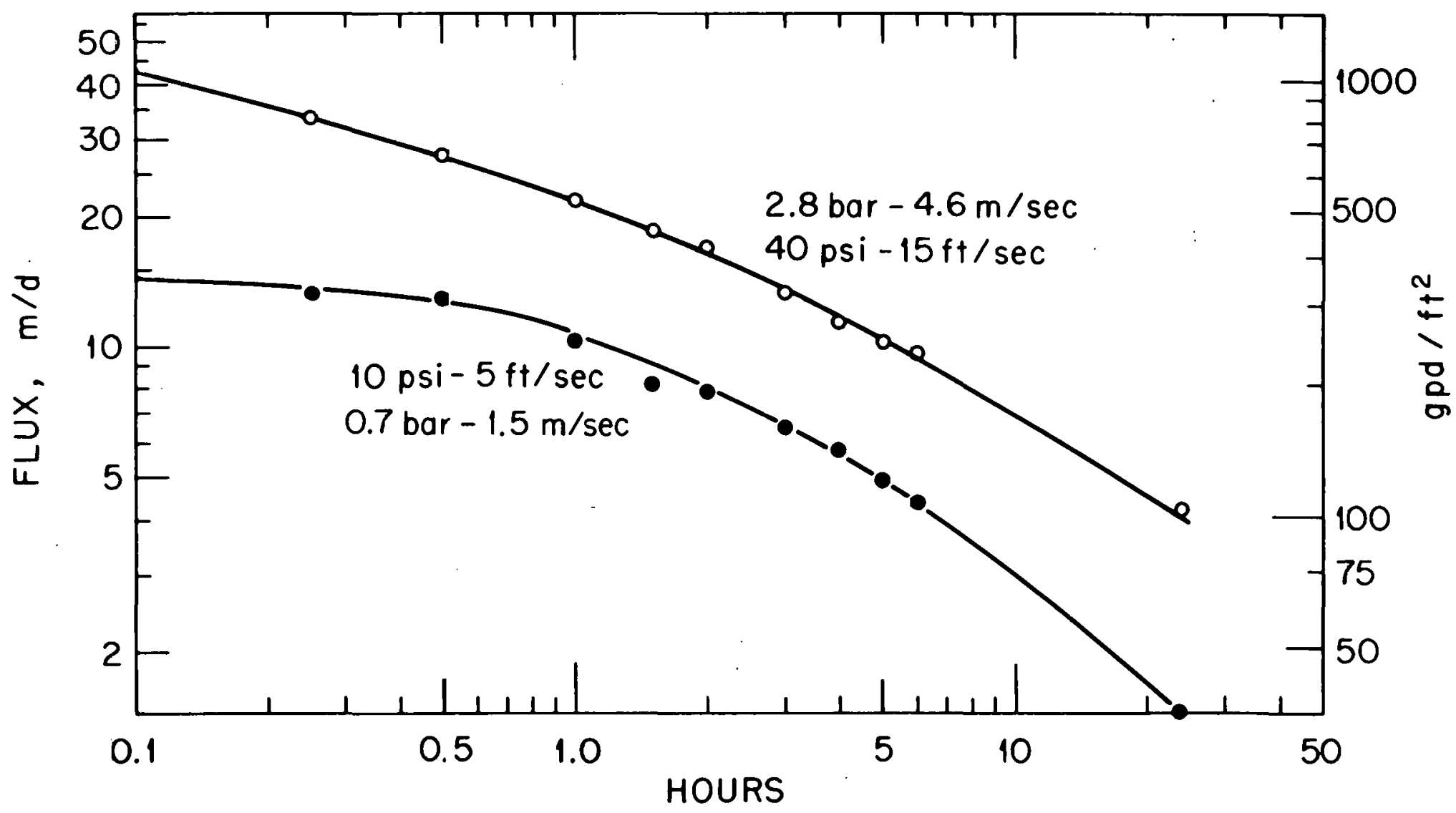

Fig. 14. Fluxes far different combinations of pressure and circulation velocity.

(Firehose jackets, ext. flow; $\mathrm{pH} 6.0$; water recovery $0-62 \%$ ) 


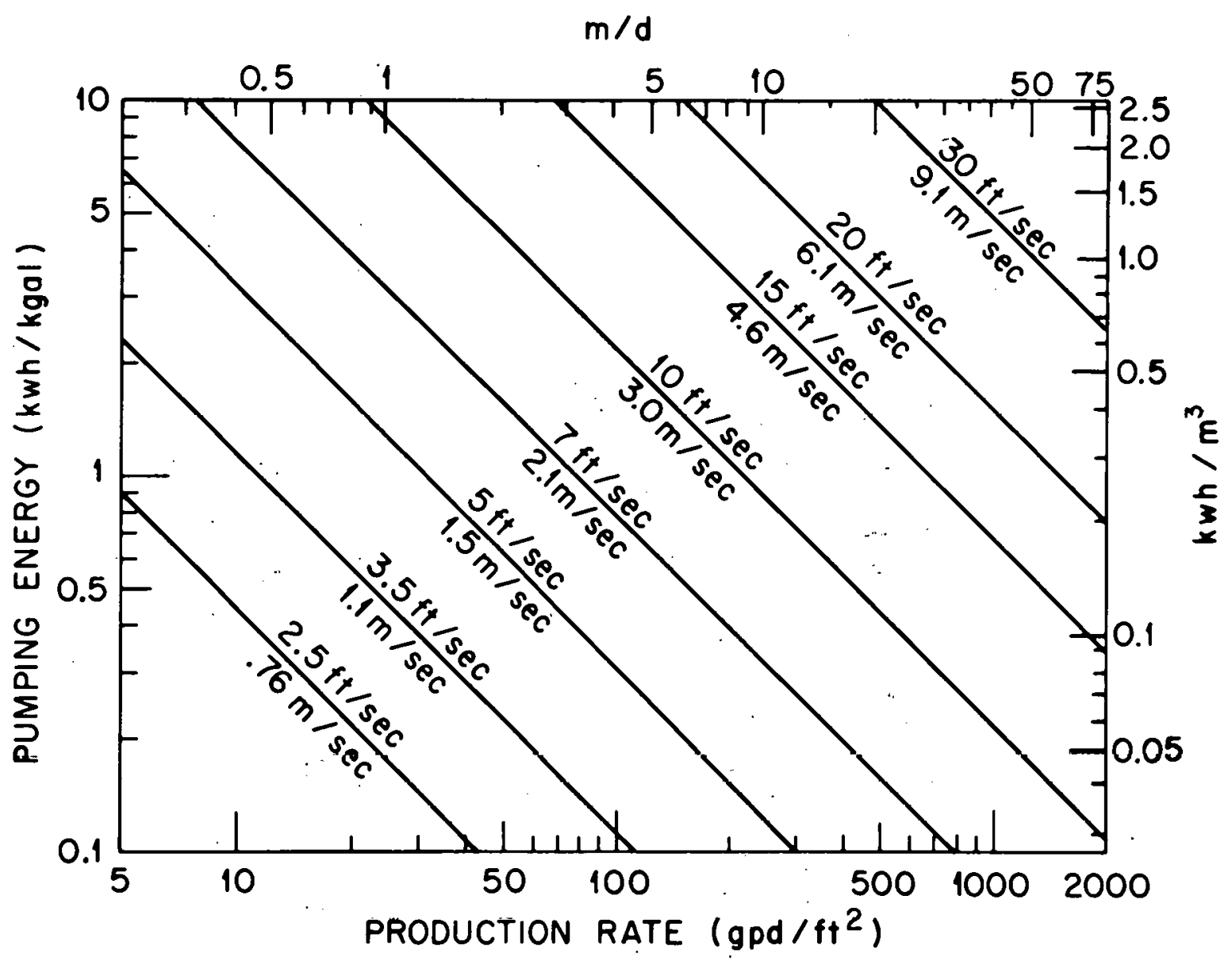

Fig. 15. Approximate pumping energy requirements in cross-flow filtration. $(1$ in $\times 20 \mathrm{ft}[2.5 \mathrm{~cm} \times 6.1 \mathrm{~m}]$ tubular filters) 
pumping energy consumption per kilogallon. Filtrate quality was essentially the same for the two test sections in Fig. 14, average (for the seven samples analyzed) TOC for the higher velocity being $15 \mathrm{ppm}$, and for the lower, $16 \mathrm{ppm}$. Average phosphate for both was $0.2 \mathrm{ppm}$.

Two pertinent tests were carried out at the ORNL plant, though circulation velocity in the first was not outside the usual range of work reported there. In it, operation with the first three pairs of modules was at $4.6 \mathrm{~m} / \mathrm{sec}(15 \mathrm{ft} / \mathrm{sec})$. A fresh pair was valved in at twenty-four hour intervals, and the system was adjusted so that the entrance pressure for the fresh pair was $275,000 \mathrm{~N} / \mathrm{m}^{2}$ (40 psi) (Fig. 16). Water recovery was brought to $75 \%$ the first day, and was maintained there subsequently. On the fourth day, a fourth fresh pair was introduced in'the same manner, except for a drop in circulation velocity to $3.6 \mathrm{~m} / \mathrm{sec}(12 \mathrm{ft} / \mathrm{sec}$ ) because of limitations of pump capability. After a short time ( 1 hr.), circulation velocity and pressure were lowered and the last pair of modules was valved in. The pressure range across it was from $150,000 \mathrm{~N} / \mathrm{m}^{2}$ (22 psi) to $55,000 \mathrm{~N} / \mathrm{m}^{2}$ ( $8 \mathrm{psi}$ ), and the circulation velocity through the system was $3 \mathrm{~m} / \mathrm{sec}(10 \mathrm{ft} / \mathrm{sec})$. The average fluxes of the module pairs over the first 24 hours onstream are listed in Table 2. It can be seen that in operation at lower pressure and circulation velocity, flux was not greatly less than the average of the first three modules, and was actually higher than for the pair, operated at higher pressure and circulation velocity, valved in a day earlier.

Table 2. A.VERAGE: FLUXES FOR THE FIRST 24 HOURS OF OPERATION

\begin{tabular}{|c|c|c|c|c|c|c|c|}
\hline Modules & $\begin{array}{c}\text { Water } \\
\text { rec. }(\%)\end{array}$ & \multicolumn{2}{|c|}{ Circ. vel. } & \multicolumn{2}{|c|}{ Pressure } & \multicolumn{2}{|c|}{ Av. flux } \\
\hline 1 and 2 & $0-75$ & 4.6 & 1.5 & $275-180$ & $40-26$ & 8.3 & 204 \\
\hline 3 and 4 & 75 & 4.6 & 15 & $275-180$ & $40-26$ & 7.5 & 184 \\
\hline 5 and 6 & 75 & 4.6 & 15 & $275-180$ & $40-26$ & 5.3 & 130 \\
\hline 9 and 10 & 75 & 3.0 & 10 & $150-55$ & $22-8$ & 6.1 & 149 \\
\hline
\end{tabular}




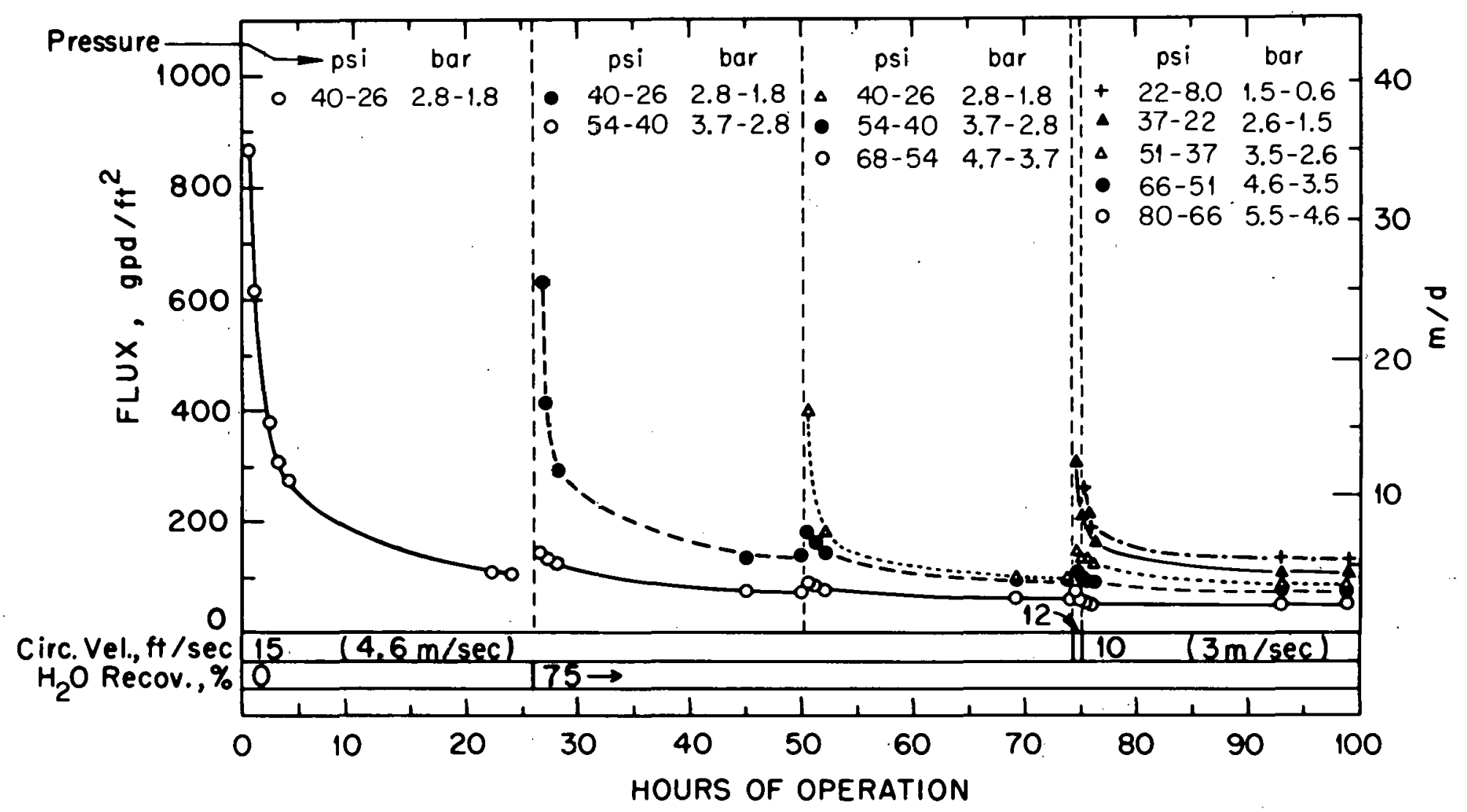

Fig. 16. Fluxes of aged and fresh pairs of modules. $(\mathrm{pH} \sim 6)$ 
In the second test, all modules were operated from the beginning at $1.5 \mathrm{~m} / \mathrm{sec}(5 \mathrm{ft} / \mathrm{sec})$, and the pressure through the system varied from $275,000 \mathrm{~N} / \mathrm{m}^{2}$ (40 psi) to $28,000 \mathrm{~N} / \mathrm{m}^{2}$ (4 psi) Fig. 17). Composite average flux for the first 24 hours was over $2.4 \mathrm{~m} / \mathrm{d}\left(60 \mathrm{gpd} / \mathrm{ft}^{2}\right)$, and fluxes for some of the modules at low pressure were higher than for those at higher pressures.

In agreement with other observations of the effect of pressure on product quality, no significant differences in TOC or phosphate in filtrate from modules at the high and low pressure ends of the system were found. In the run summarized in Fig. 16, most filtrate TOC values fell between 5 and $10 \mathrm{mg} / \ell$ with a few being higher or lower; phosphates were 0.1 to 0.5 $\mathrm{mg} / \mathrm{l}$. In the run of Fig. 17, average TOC for 38 analyses was $7.6 \mathrm{mg} / \mathrm{l}$.

These measurements cannot establish conditions for an economic optimum, which will vary as relative energy and capital costs vary. However, the tests cited strongly suggest that future work should pay more attention to low-circulation-velocity, low-pressure operation than we have accorded it so far.

Effect of Water Recovery

Fluxes might be expected to decline much more rapidly when the filters are exposed to solutions from which a large fraction of the water has been removed, since both impurities and added iron or aluminum are at higher concentration. $^{28}$ Experience, however, has been different. No great differences, over. scatter, in fluxes after the same period of operation have been apparent in runs at least up to $90 \%$ water recovery.

The pattern, which was observed generally during the study, is illustrated by results of several runs at the ORNL pilot plant. ${ }^{23}$ Scatter in fluxes during the early stages of different runs is substantial (Fig. 18) but is not clearly related to the degree of recovery. In some runs, fresh modules were substituted for adjacent modules (pressure range over the modules would therefore be the same) after a certain water recovery was attained. It can be seen in Figs. 19, 20, and 21 that fluxes were not greatly lower for the modules exposed from the start to the concentrated solution than for those initially exposed to dilute feed. 


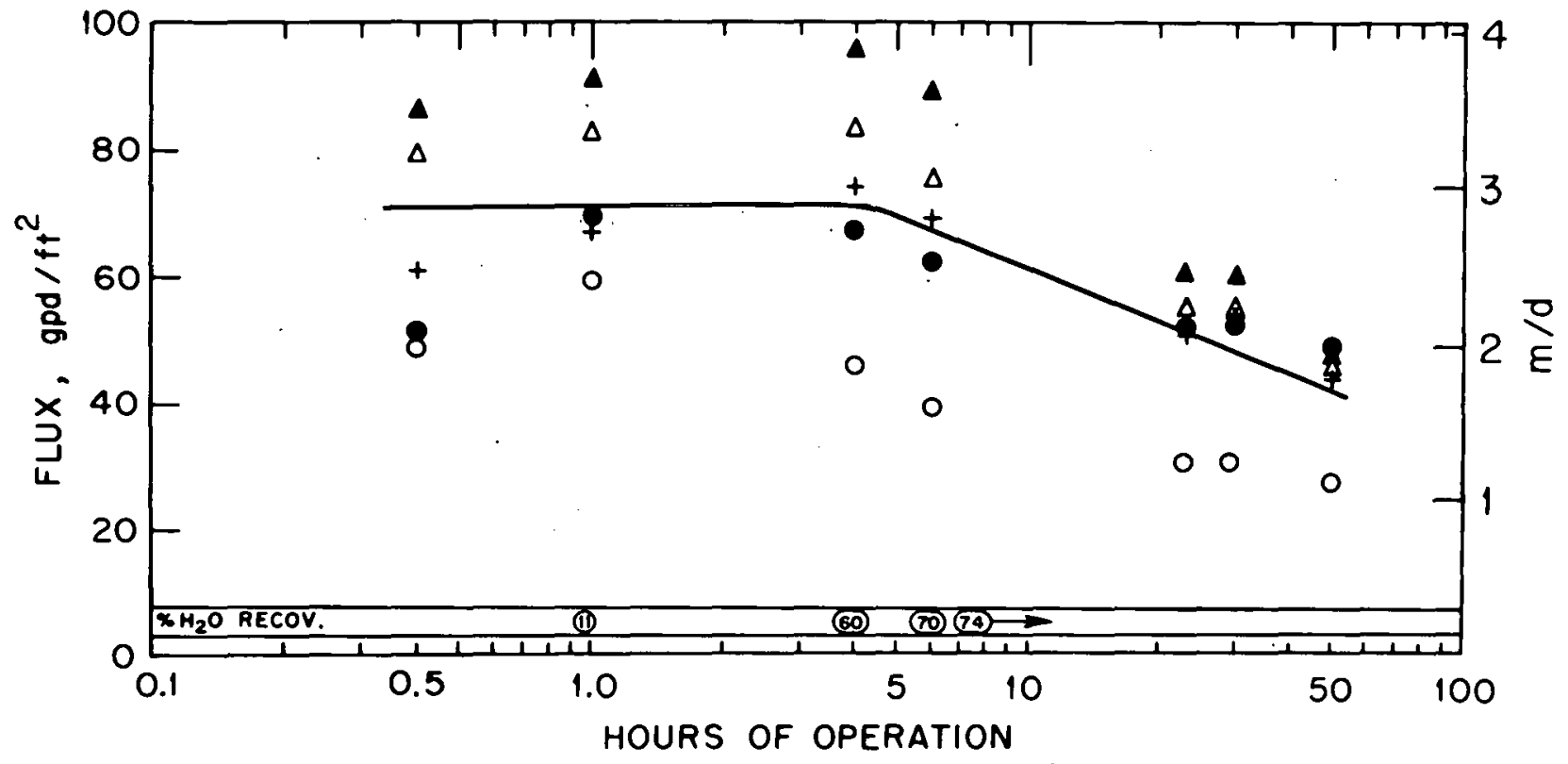

Fig. 17. Low-pressure - low-circulation velocity cross-flow filtration of primary sewage.

(65 ppm Fe; pH $\sim 6 ; .5 \mathrm{ft} / \mathrm{sec}[1.5 \mathrm{~m} / \mathrm{sec}])$

\begin{tabular}{llll} 
& Modules & psi & bar \\
\hline & $1 \& 2$ & $40-33$ & $2.8-2.3$ \\
$-\quad 3 \& 4$ & $33-26$ & $2.3-1.8$ \\
$\Delta$ & $5 \& 6$ & $26-18$ & $1.8-1.2$ \\
- & $7 \& 8$ & $18-11$ & $1.2-0.8$ \\
+ & $9 \& 10$ & $11-4$ & $0.8-0.3$ \\
\end{tabular}




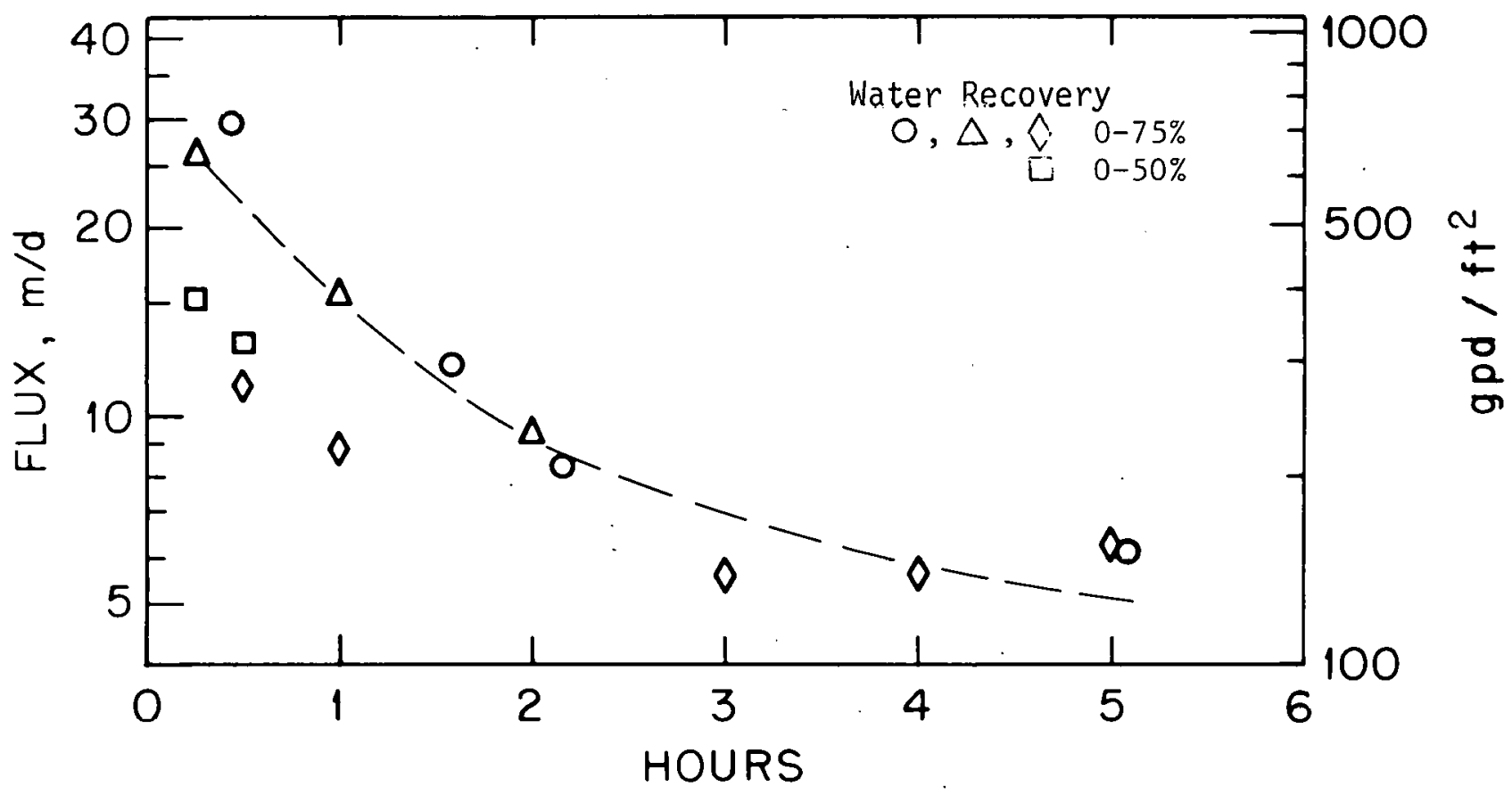

Fig. 18. Comparison of fluxes during initial stages of several runs at ORNL pilot plant.

(15-80 psig $[1.0-5.5 \mathrm{bar}] ; 15 \mathrm{ft} / \mathrm{sec}[4.6 \mathrm{~m} / \mathrm{sec}] ; 50-70 \mathrm{ppm}$ iron) 


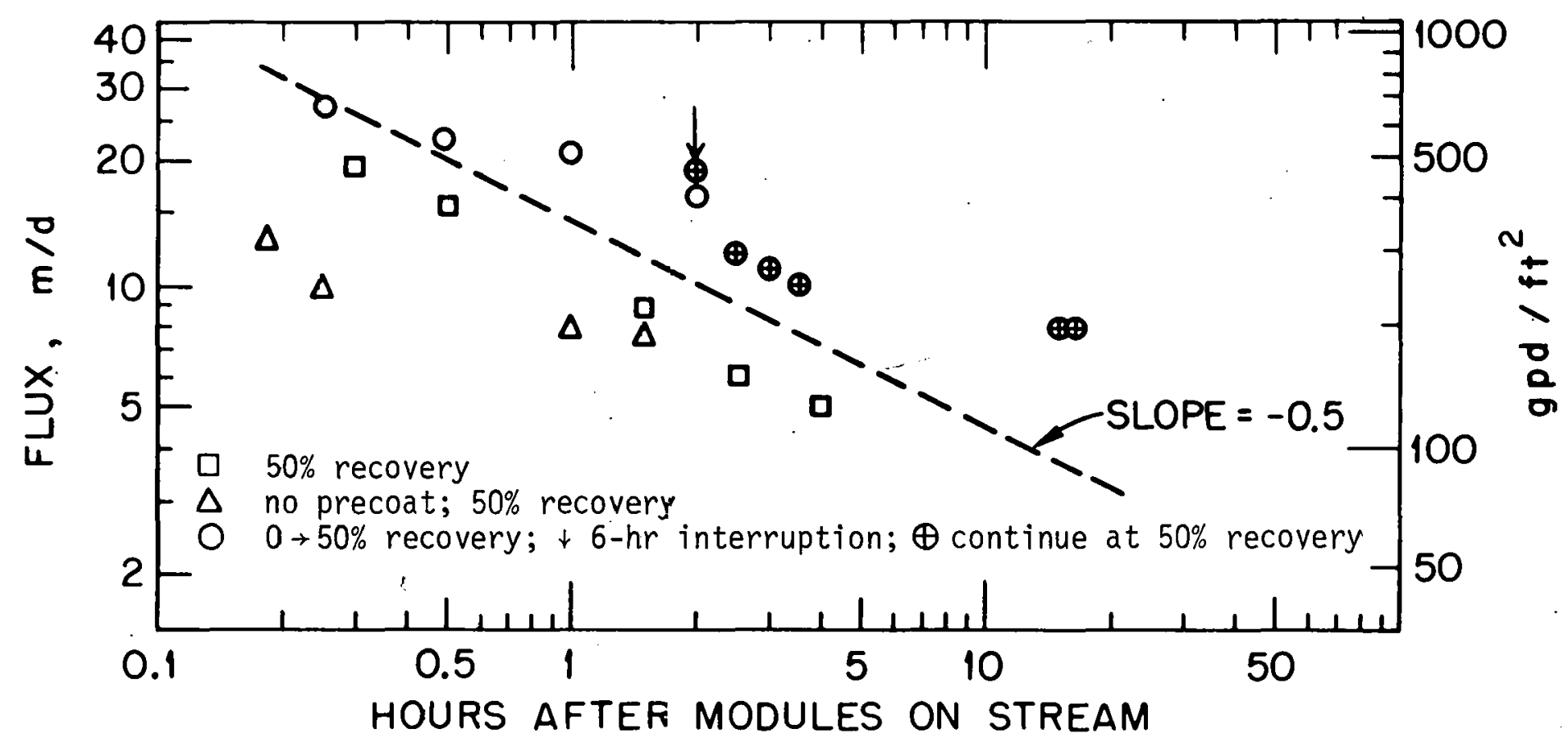

Fig. 19. Fluxes, precoated and non-precoated modules. (60-80 psi [4.1-5.5 bar]; $70 \mathrm{ppm}$ iron; $15 \mathrm{ft} / \mathrm{sec}[4.6 \mathrm{~m} / \mathrm{sec}]$ ) 


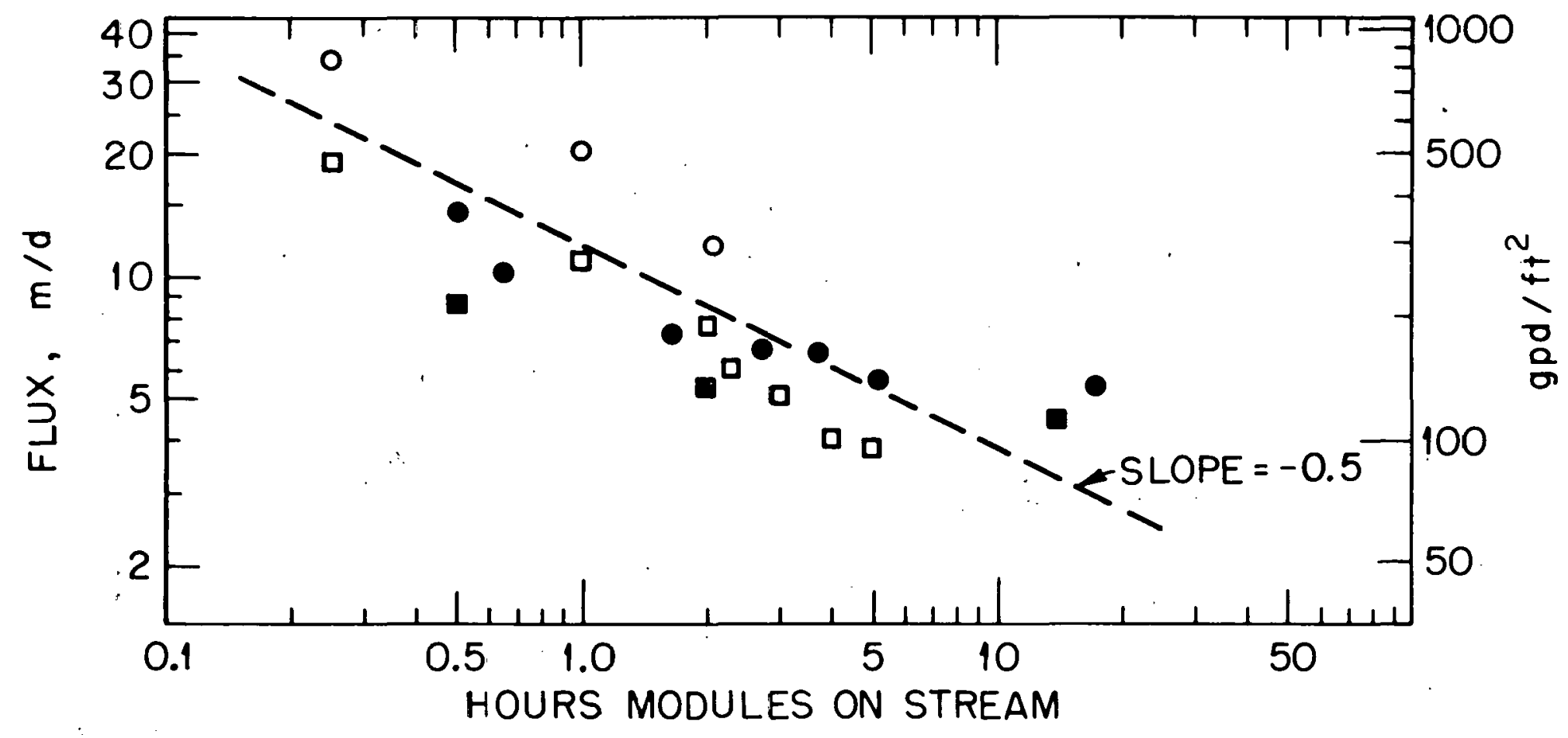

Fig. 20. Flux decline at different pressures and recoveries.

(15 ft/sec $[4.6 \mathrm{~m} / \mathrm{sec}] ; 70 \mathrm{ppm}$ iron)

\begin{tabular}{c|c|c}
\multirow{2}{*}{ Recovery } & \multicolumn{2}{|c}{ Pressure } \\
\cline { 2 - 3 } & $\begin{array}{c}60-80 \\
4.1-5.1\end{array}$ & $15-30$ psig \\
& $4.0-2.1$ bar \\
\hline $0-75 \%$ & 0 & $\square$ \\
$75 \%$ & $\bullet$ & $\square$
\end{tabular}




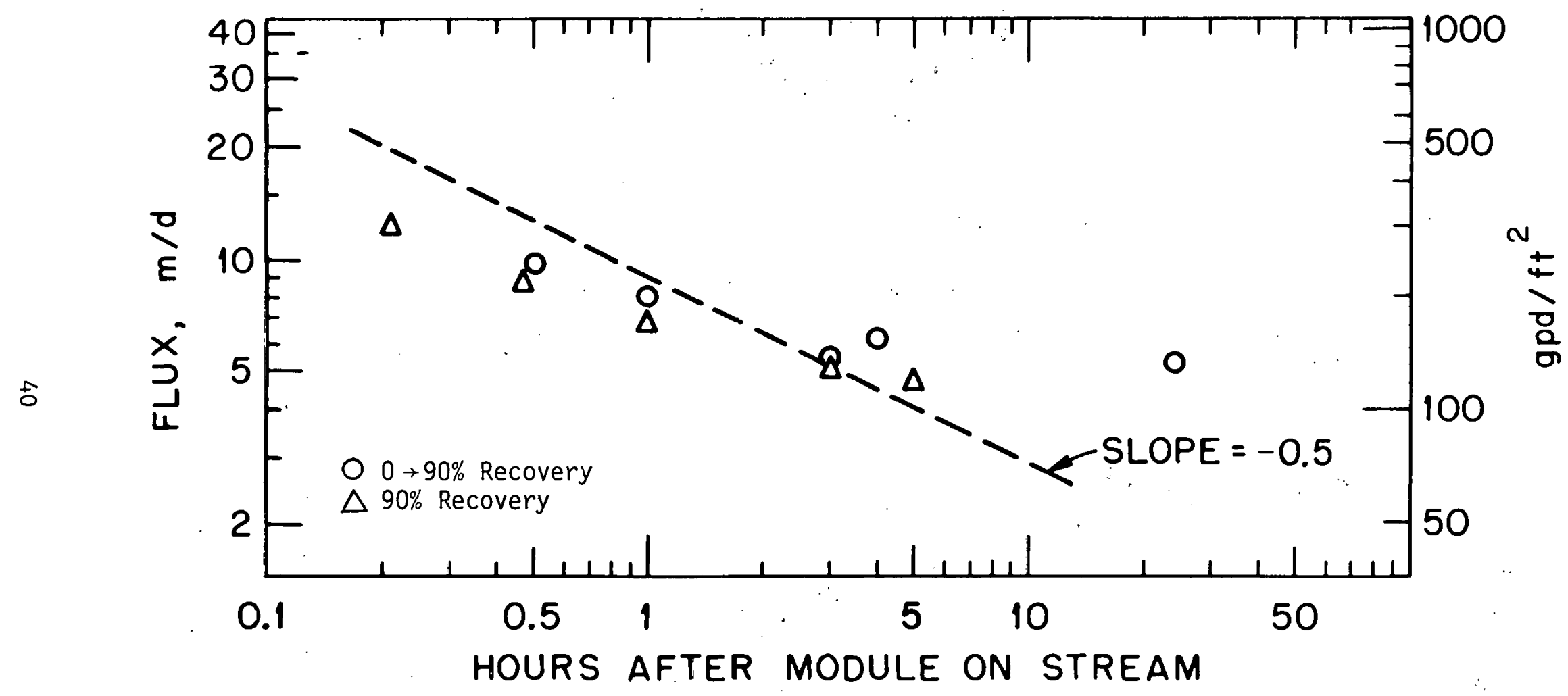

Fig. 21. Fiuxes at high water recovery.

(35-55 psig [2.4-3.8 bar]; $15 \mathrm{ft} / \mathrm{sec}[4.6 \mathrm{~m} / \mathrm{sec}] ; 40 \mathrm{ppm}$ iron) 
The insensitivity to pressure and water recovery implies that in projecting performance, variations in flux from pressure drop along the system and from increased water recovery can be ignored to a first approximation.

Effect of Temperature

Temperature effects appear to be mainly on fluxes, which vary roughly as the inverse of viscosity, after filtercakes are stabilized. Figure 22 summarizes results of two temperature scans made at different times in a run. The earlier results were taken as fluxes were declining rapidly, but the departure from dependence on fluidity involves more than flux decline, since the $60^{\circ} \mathrm{C}$ point was the next to last measurement in the scan, just before a repeat at $33^{\circ} \mathrm{C}$. However, fluxes measured the next day paralleled fluidity variations.

The only filtrate analyses available for this run were taken at $60^{\circ} \mathrm{C}$ the first day. They seemed fairly normal, though TOC was somewhat higher than usual: TOC, $20 \mathrm{mg} / \mathrm{l}$ (int), 19 (ext); phosphate, $0.5 \mathrm{mg} / \mathrm{l}$ (int), 0.4 (ext); Fe total, 0.06 (int), 0.01 (ext); turbidity, 1. JTU (int), $<0.2$ (ext). The run was carried out at $\mathrm{pH}$ about 7 , and primary effluent feed TOC ranged from 56 . to $89 \mathrm{mg} / \mathrm{l}$ and phosphate from 25 to $43 \mathrm{mg} / \mathrm{l}$.

\section{EFFE'C' OF ADDITIVES}

Removal. of $P(V)$ by Hydrolyzable Ion Addition

An important purpose of the addition of $\mathrm{Fe}(\mathrm{III})$ and $\mathrm{Al}$ (III) salts is removal of phosphorus. Since phosphorus in sewage can occur in many chemical forms, prediction of necessary additive levels and of removal efficiency is complicated. In addition, as one. would expect, ${ }^{30}$ residual phosphate is affected by $\mathrm{pH}$, presence of other ions, and the completeness of solid-1iquid separations. Increased removal from acidic solution caused by presence of sulfate and from basic solution by presence of $\mathrm{Ca}$ (II) was attributed to agglomeration of finely dispersed ferric. phosphate precipitates. 31

Figure 23 summarizes results of tests of removal of $P(V)$ at the nak Ridge municipal plant. Fexric chloride was addcd to the initial 


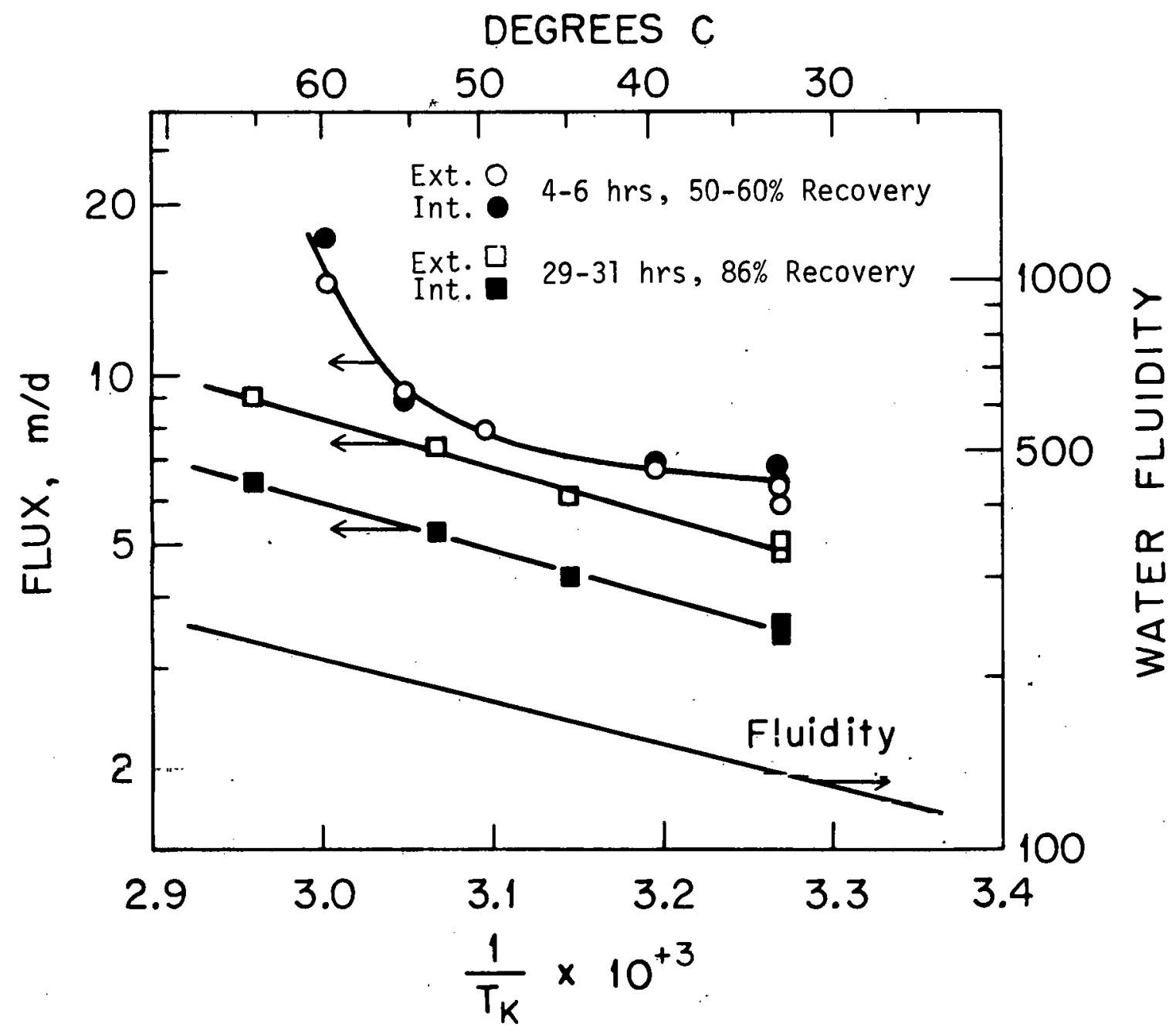

Fig. 22. Effect of temperature on flux.

(15 $\mathrm{ft} / \mathrm{sec}[4.6 \mathrm{~m} / \mathrm{sec}] ; 50 \mathrm{ppm} F e($ III)) 


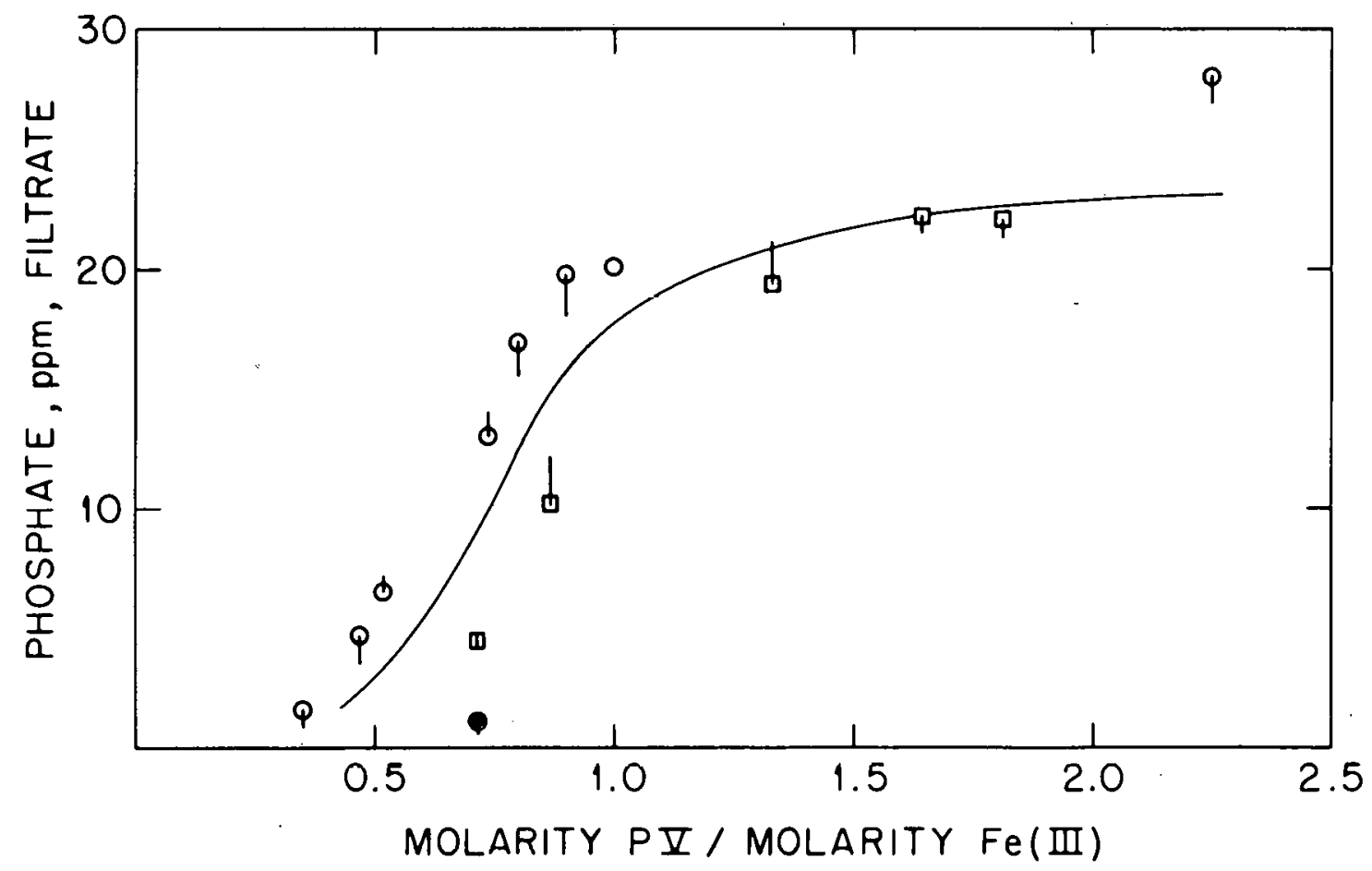

Fig. 23. Dependence of phosphate in filtrate on ratio of phosphate to ferric in feed.

$$
\text { (40 psi [2.8] inlet; } \mathrm{pH} \sim 4 \text { ) }
$$

p Initial Fe(II), $36 \mathrm{ppm}$;

- $\mathrm{Fe}$ (III) added to $70 \mathrm{ppm}$ after day of operation

甲 Initial $\mathrm{Fe}(\mathrm{II}), 18 \mathrm{ppm}$

$\uparrow_{---} T_{-}$outside flow 
charge of primary effluent at $18 \mathrm{mg} / \ell \mathrm{Fe}($ III) in one run and at $36 \mathrm{mg} / \ell$ in the other, and acidity was adjusted to $\mathrm{pH} 4$ with $\mathrm{H}_{2} \mathrm{SO}_{4}$. No further ferric salt was added as primary effluent was brought in to replace discarded filtrate, though the $\mathrm{pH}$ was kept about 4 by acid addition. By periodic analysis of incoming sewage, with correction for $P(V)$ in the filtrate, the $\mathrm{P}(\mathrm{V}) / \mathrm{Fe}(\mathrm{III})$ mole ratio in the solution circulating past the filters was estimated. It can be seen that phosphate in the filtrate became substantial above mole ratios of total phosphorus to iron of roughly 0.5 ; the difference between the two runs are within uncertainties in concentration. Addition of more iron at the end of one run brought phosphate in the filtrate again to a low level. There appears to be no significant difference between removal with circulation outside and inside the fire-hose jackets.

These results are reasonably consistent with trends of reported laboratory data. 30,31 Mole ratios of $\mathrm{Fe}($ III) to total $\mathrm{P}(\mathrm{V})$ of a little higher than 2:1 appear adequate for good phosphorus removal. We have not carried out similar tests at other $\mathrm{pH}$ values nor with $\mathrm{Al}$ (III), but our experience at the $\mathrm{Al}$ (III) or $\mathrm{Fe}$ (III)/P(V) ratios used in this program, usually higher than 2, indicates that filtrates were usually lower than $1 \mathrm{mg} / \mathrm{l}$ as $\mathrm{PO}_{4}{ }^{3-}$ at the acidities of most runs ( $\mathrm{pH}$ range 3 to 7 ). Effects of Hydrolyzable Ions and $\mathrm{pH}$ on Flux

Besides removing phosphorus compounds as solids, $\mathrm{Fe}$ (III) and Al(III) hyd̈rous oxide precipitates also appear to react with other sewage constituents. Some sewage substances form on porous supports layers of low permeability, filtering salt at high pressures. 32,33 ' In the interest of maintaining economically attractive fluxes, one would hope Fe(III) and Al(III) additives would tie up components forming tight dynamic membranes.

Figure 24 summarizes an experiment with aqueous solutions (not sewage) illustrating this possibility. Cross-flow filtration of a solution containing polyacrylic acid (PAA) and an Al(III) salt was carried out, with varying ratios of $A I$ (III) to PAA. Change after 2.5 hours from a ratio moles Al(III)/moles carboxylate groups of slightly under 1 to ca. 0.5 caused a precipitous increase in the rate of flux decline. Return to the earlier ratio arrested decline, but did not restore flux. A further 


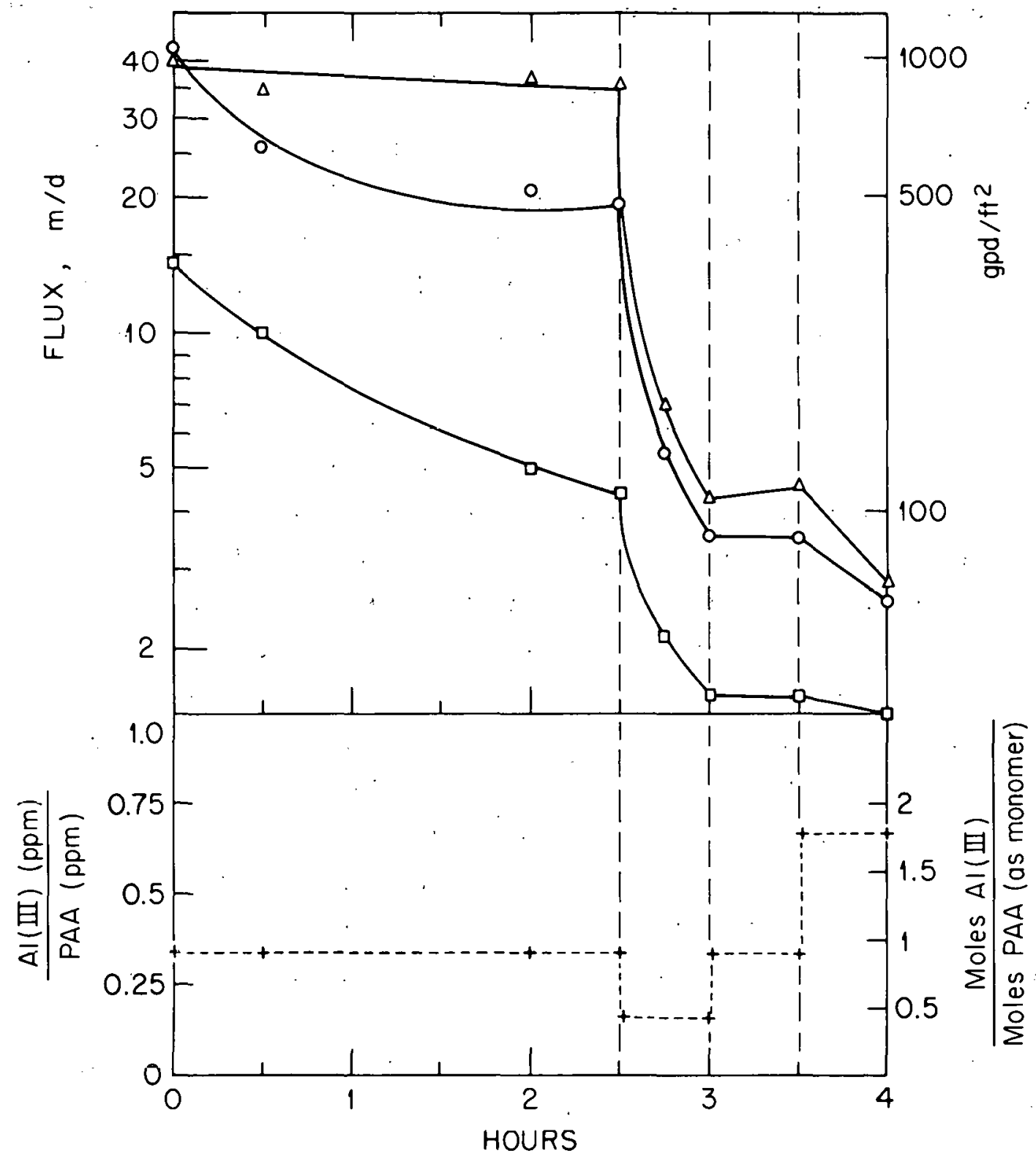

Fig. 24. Effect of ratio of $A 1$ (III) to polyacrylate on flux in filtration.

(Tnitial. ppm Al(III), 50; polyacrylic acid [PAA] in water; 20 psi [1.4 bar]; pH 4.5-7)

Precoated $\quad \int 040$ mesh, $15 \mathrm{ft} / \mathrm{sec}(4.6 \mathrm{~m} / \mathrm{sec})$ Stainless Steel $\left\{\begin{array}{l}\Delta 40 \mathrm{mesh}, 15 \mathrm{ft} / \mathrm{sec}(4.6 \mathrm{~m} / \mathrm{sec}) \\ \text { a } 40 \mathrm{mesh}, 0 . \mathrm{ft} / \mathrm{sec}(0.03 \mathrm{~m} / \mathrm{sec})\end{array}\right.$ Screens $\quad 20$ mesh, $0.1 \mathrm{ft} / \mathrm{sec}(0.03 \mathrm{~m} / \mathrm{sec})$ 
increase in metal ion/polyelectrolyte ratio increased the decline rate. Apparently there is an optimal ratio of the positively charged to the negatively charged high molecular weight species.

Behavior of sewage is qualitatively similar. Figure 25 compares fluxes obtained at the Oak Ridge municipal plant with three solutions: primary effluent containing no additive; water and added ferric salt (10 mg/ $\ell \mathrm{Fe}(\mathrm{III})$ ); and primary effluent with added ferric salt (ca. $50 \mathrm{mg} / \ell \mathrm{Fe}(\mathrm{III}))$. Fluxes with sewage feed are much higher when $\mathrm{Fe}$ (III) has been added. More surprisingly, fluxes with primary effluent and $\mathrm{Fe}$ (III) are somewhat higher than with water and $\mathrm{Fe}$ (III), even though the concentration of iron was less in the water solution.

What additive level is optimal for flux is in doubt. The answer from results discussed here appears to be that there is a rather broad range above that necessary for phosphate removal in which flux seems relatively insensitive to $\mathrm{Fe}($ III) and $\mathrm{Al}$ (III) concentration. Filtrate quality also appears not to vary much with additive level. These trends disagree with preliminary results obtained in laboratory experiments, reported earlier (Fig. 6.29, Ref. 34) (see Discussion).

We illustrate for $\mathrm{Fe}$ (III) with results from two sets of runs, each run of approximately 24 hours' duration and carried out under similar conditions, except as noted. The test sections were precoated with asbestos fibers, and the sewage effluent was processed by the cycle outlined in Fig. 1, iron being introduced as $\mathrm{FeCl}_{3}$. On replacing the precoating slurry with treated sewage, the initial filtrate is turbid, but after a few minutes becomes clear. (Detailed histories of typical runs can be seen in the first stage results of Figs. 45-47, to be discussed in connection with two-stage treatment.) In both sets of runs discussed here, filtrate was discarded. The water recovery attained varied with flux and with area of filtering surface; filtrate volumes ranged between 64 and $96 \%$ of the volume of sewage effluent taken in.

The first set was obtained between February and May of 1973. Figures 26 and 27 give the results as a function of Fe(III) concentration observed at two hours and the average over 24 hours, respectively; approximate experimental conditions are indicated in the figures. Although there is considerable scatter, there does not appear to be any clear 


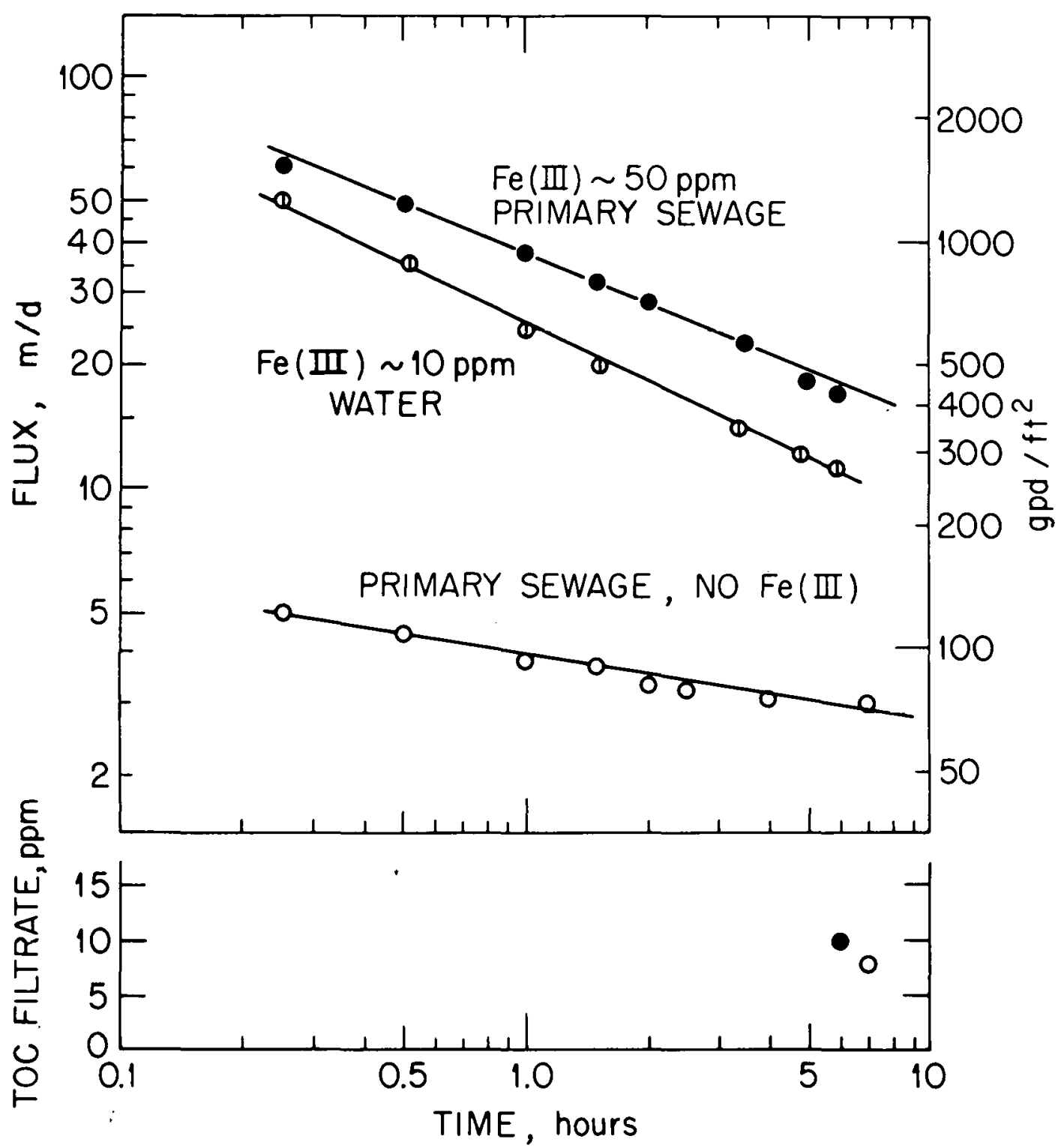

Fig. 25. Cross-flow filtration of primary sewage with and without $\mathrm{Fe}$ (III) addition.

(Fire-hose jackets, external flow; $15 \mathrm{ft} / \mathrm{sec}[4.6 \mathrm{~m} / \mathrm{sec}]$; 40 psi [ 2.8 bar ]) 


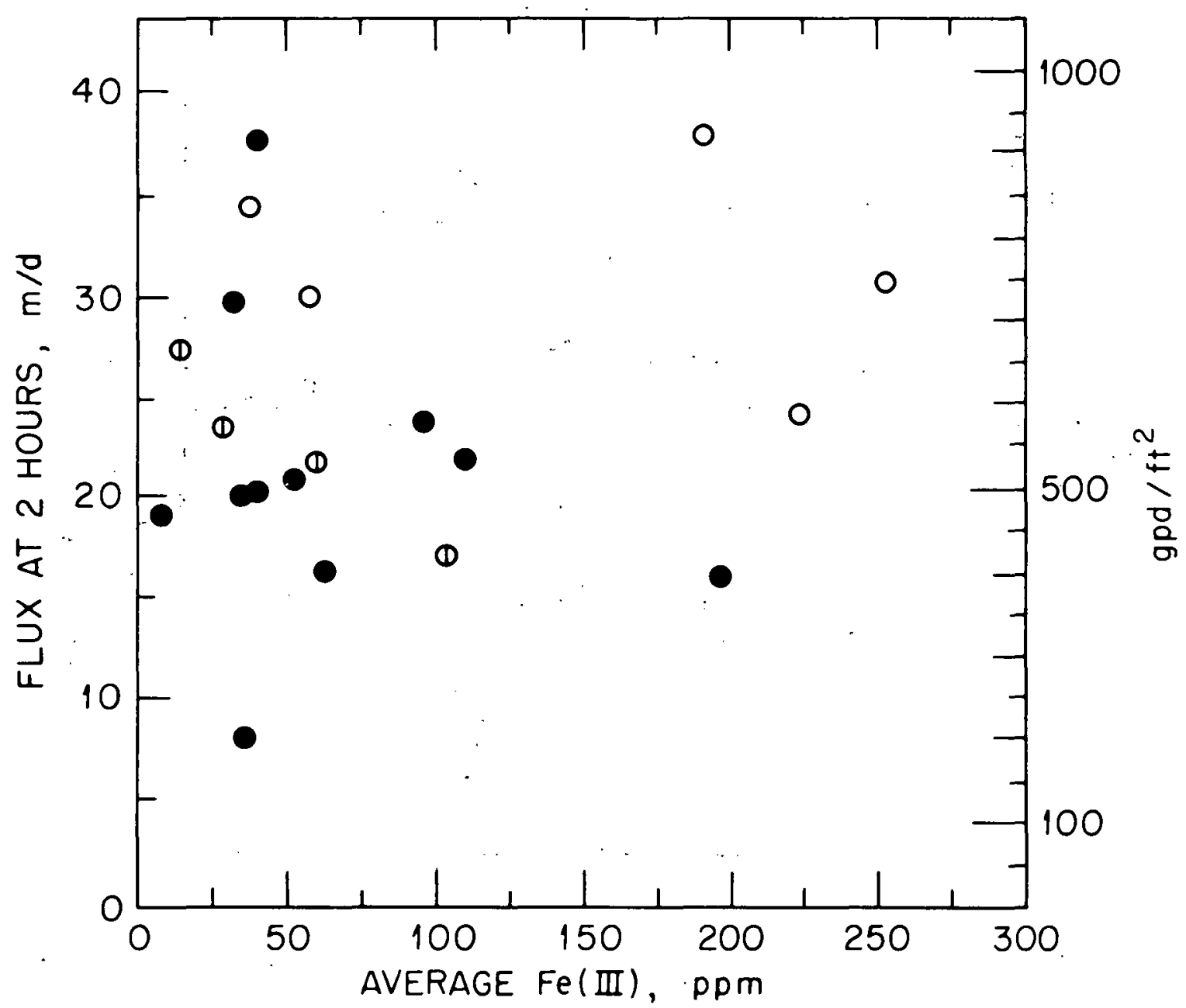

Fig. 26. Fluxes at two hours, cross-flow filtration of sewage effluent.

(Fire-hose jackets, internal and external flow; 40 psi [2.8 bar] at inlet; 10 to $15 \mathrm{ft} / \mathrm{sec}$ [ 3 to $4.6 \mathrm{~m} / \mathrm{sec}$ ])

- $\mathrm{pH}$ 4.0 Primary Sewage

- $\mathrm{pH} 6.0$ Primary Sewage (after air-sparge at $\mathrm{pH} 3$ )

(1) pH 4.0 Secondary Sewage 


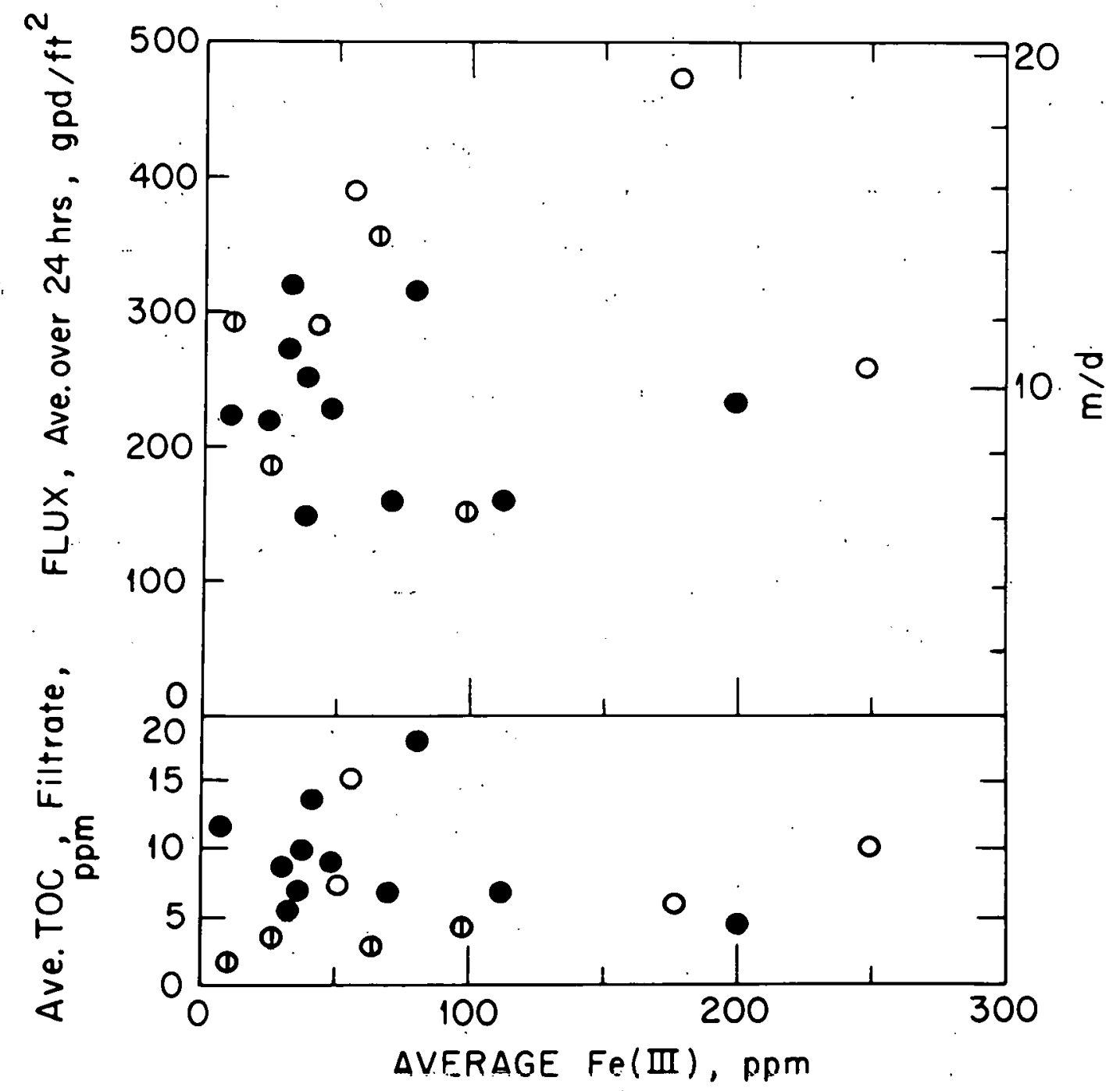

Fig: 27. Correlation of flux and filtrate quality with Fe(III) addition. (Fire-hose jackets, internal and external flow; 40 psi [2.8 bar] at inlet; 10 to $15 \mathrm{ft} / \mathrm{sec}$ [ 3 to $4.6 \mathrm{~m} / \mathrm{sec}$ ])

- $\mathrm{pH} \sim 4.0$ Primary Sewage

$\circ \mathrm{pH} \sim 6.0$ Primary Sewage

(Air-sparged at pH 3)

(1) $\mathrm{pH} \sim 4.0$ Secondary Sewage 
influence of the Fe(III) concentration on flux or filtrate TOC under these conditions. From these results, it appears that, with 24-hour regeneration cycles, average fluxes of $8-12 \mathrm{~m} / \mathrm{d}\left(200-300 \mathrm{gpd} / \mathrm{ft}^{2}\right) \mathrm{might}$ be attained. There does not appear to be a significant difference between fluxes obtained with primary effluent and fluxes obtained with secondary effluent. Organic carbon in the filtrate, however, is lower with secondary effluent as feed. In this set average fluxes obtained in operation at $\mathrm{pH} 4$ seem to be somewhat less than in operation at $\mathrm{pH} 6$ (after air sparging at $\mathrm{pH} 3$ ), though these results do not allow a definite conclusion because of the large scatter. The principal disadvantage of the filtering at low $\mathrm{pH}$ is that the filtrate is contaminated with iron, frequently several $\mathrm{mg} / \mathrm{l}$.

Conceivably, the amount of $\mathrm{Fe}$ (III) relative to organic contaminants in the sewage is a controlling variable. Figure 28 presents the results of Fig. 27, plotted against the ratio of $\mathrm{Fe}(\mathrm{III})$ to the average TOC concentration in the primary or secondary sewage effluent feed. Correlation is no better than with $\mathrm{Fe}$ (III) concentration. There is also no apparent correlation with the average TOC in the feed (Fig. 29), nor with the average TOC in the filtrate (Fig. 30). (The set of experiments plotted in Figs. 29 and 30 differs slightly from the set in Figs. 26 and 27.)

The second set of results was obtained September 1973-January 1974 . Figures 31 and 32 summarize these results (not all tests in Fig. 31 were continued for 24 hours). The main difference between the sets is that 24-hour averages in Fig. 32 scatter about $6 \mathrm{~m} / \mathrm{d}\left(150 \mathrm{gpd} / \mathrm{ft}^{2}\right)$, while fluxes in the earlier set were higher, those in Fig. 27 clustering around $10 \mathrm{~m} / \mathrm{d}$ (250 gpd $/ \mathrm{ft}^{2}$ ). Closer examination indicates fairly good agreement between filtrations carried out near $\mathrm{pH} 4$, the mean of the 24-hour averages being a little above $8 \mathrm{~m} / \mathrm{d}$ ( $200 \mathrm{gpd} / \mathrm{ft}^{2}$ ). However, the average for those of the second set carried out near neutral $\mathrm{pH}$ was only $4.7 \mathrm{~m} / \mathrm{d}$ (115 gpd $\left./ \mathrm{ft}^{2}\right)$, in comparison with $14.3 \mathrm{~m} / \mathrm{d}$ (350 gpd $/ \mathrm{ft}^{2}$ ) in the first set. The $\mathrm{Fe}$ (III)/TOC ratio appears also in the Fig. 32 set to be no more significant than in Fig. 28 (Fig. 33).

Reasons for the differences are not clear. The $\mathrm{pH}$ at which the neutral-range filtrations were carried out tended to be somewhat higher in the second set (Fig. 32), but fluxes in more recent experiments in 


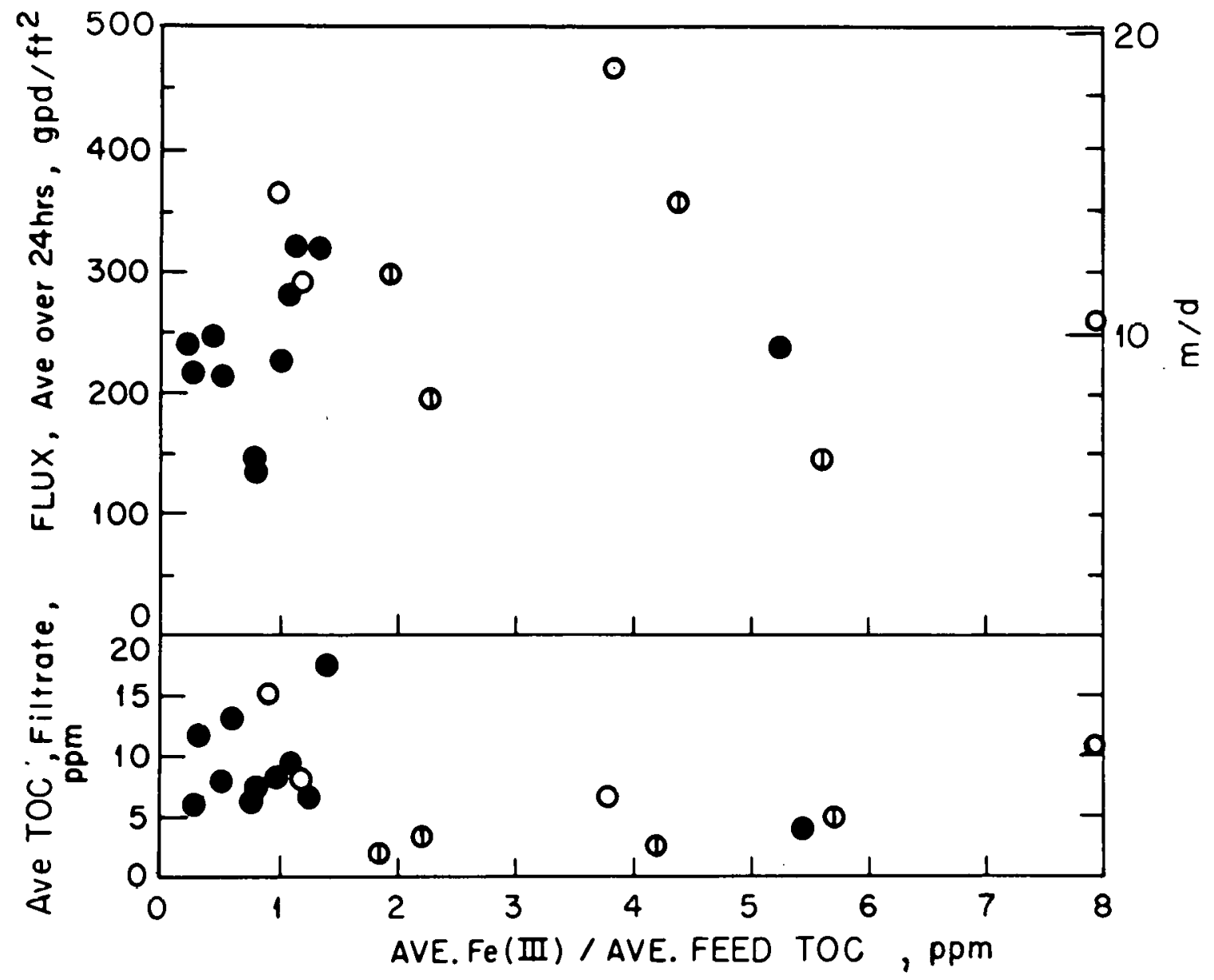

Fig. 28. Correlation of flux and filtrate quality with Fe(III) and organic carbon level.

- $\mathrm{pH} \sim 4.0$ Primary Sewage

- $\mathrm{pH} \sim 6.0$ Primary Sewage

(Air-sparged at $\mathrm{pH} 3$ )

- $\mathrm{pH} \sim 4.0$ Secondary Sewage 


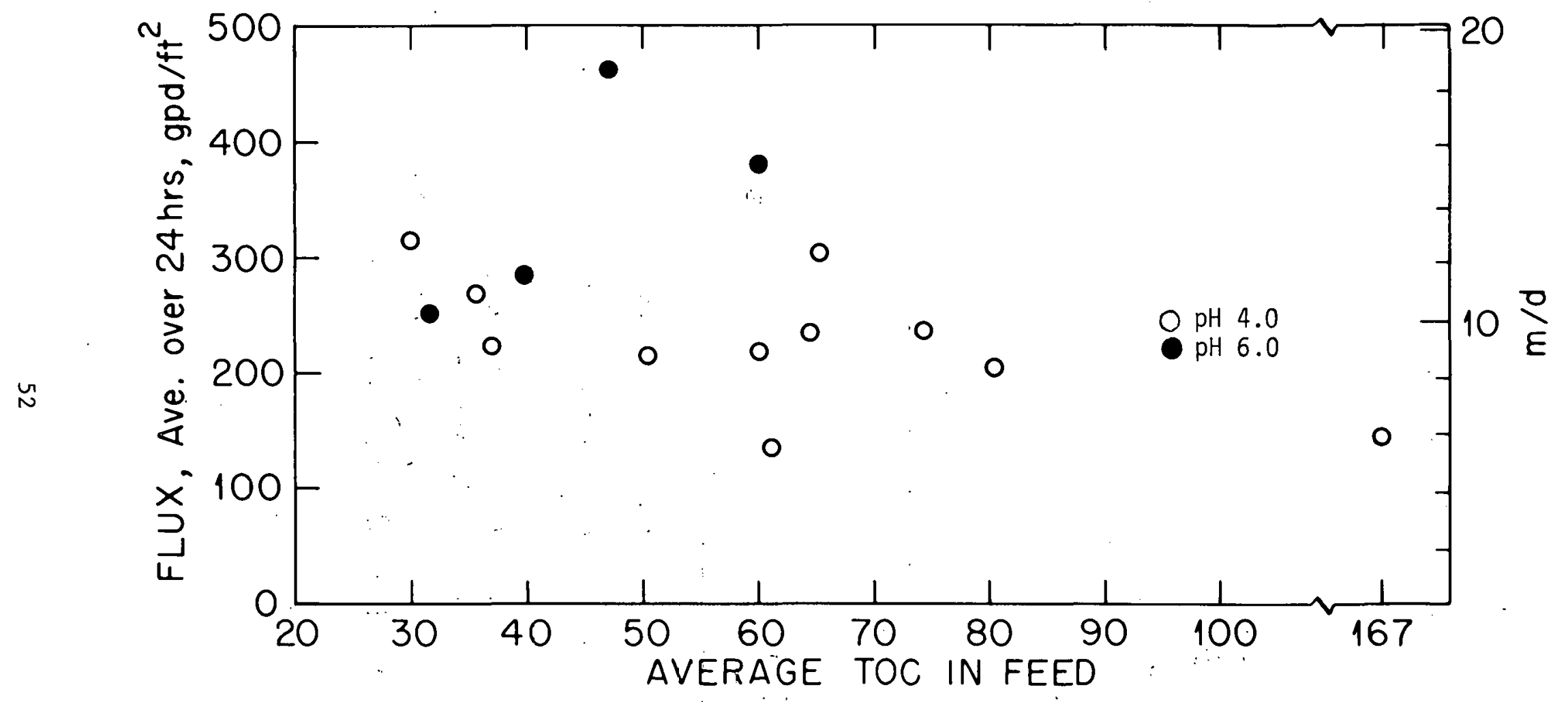

Fig. 29. Correlation of average flux with organic carbon in feed.

(Erimary sewage) 


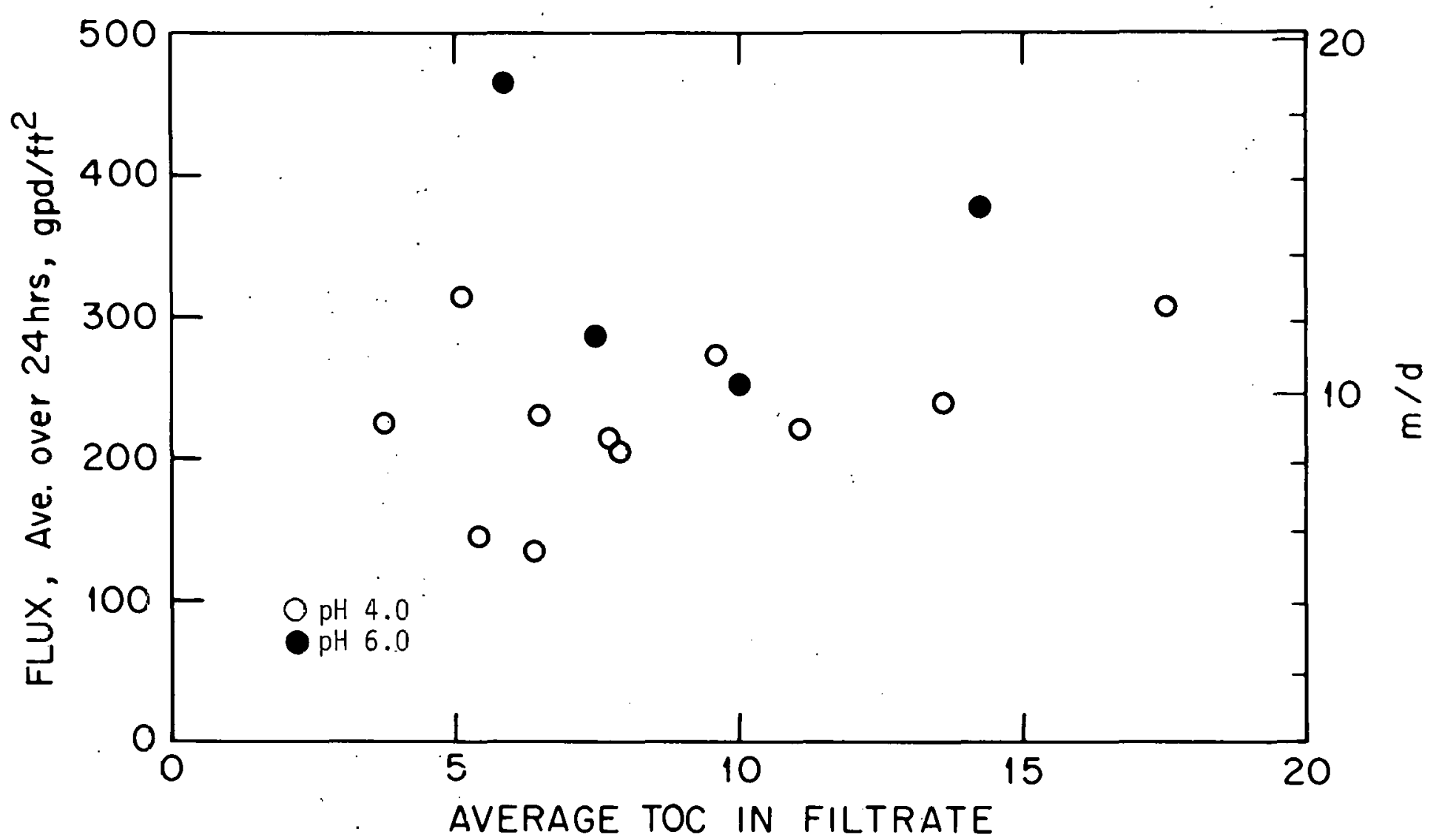

Fig. 30. Correlation of average flux with organic carbon in filtrate. 


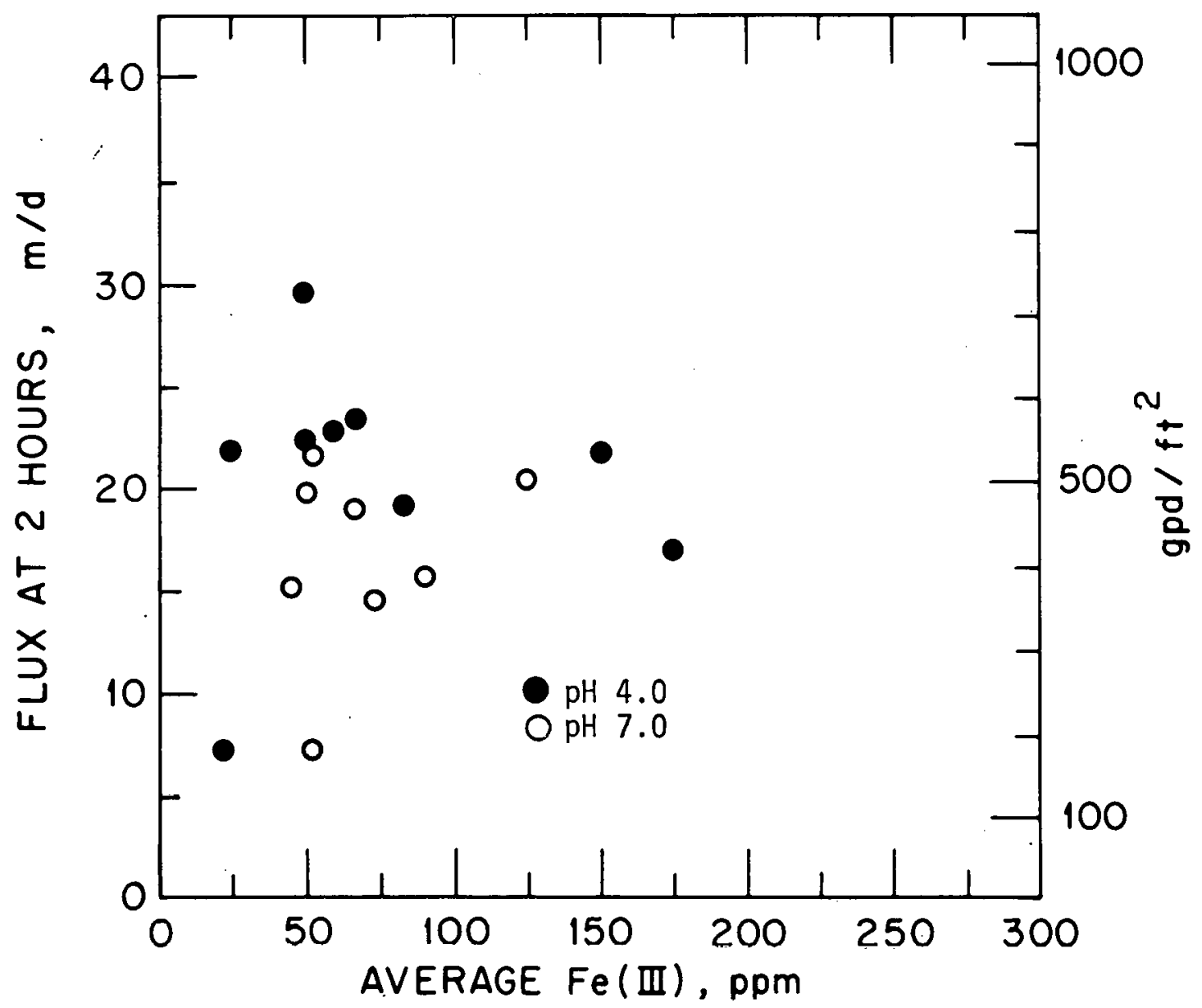

Fig. 31. Fluxes at two hours, cross-flow filtration of primary sewage. (Fire-hose jackets, external flow; 40 psi [2.8 bar] at inlet; $15 \mathrm{ft} / \mathrm{sec}[4.6 \mathrm{~m} / \mathrm{sec}])$ 


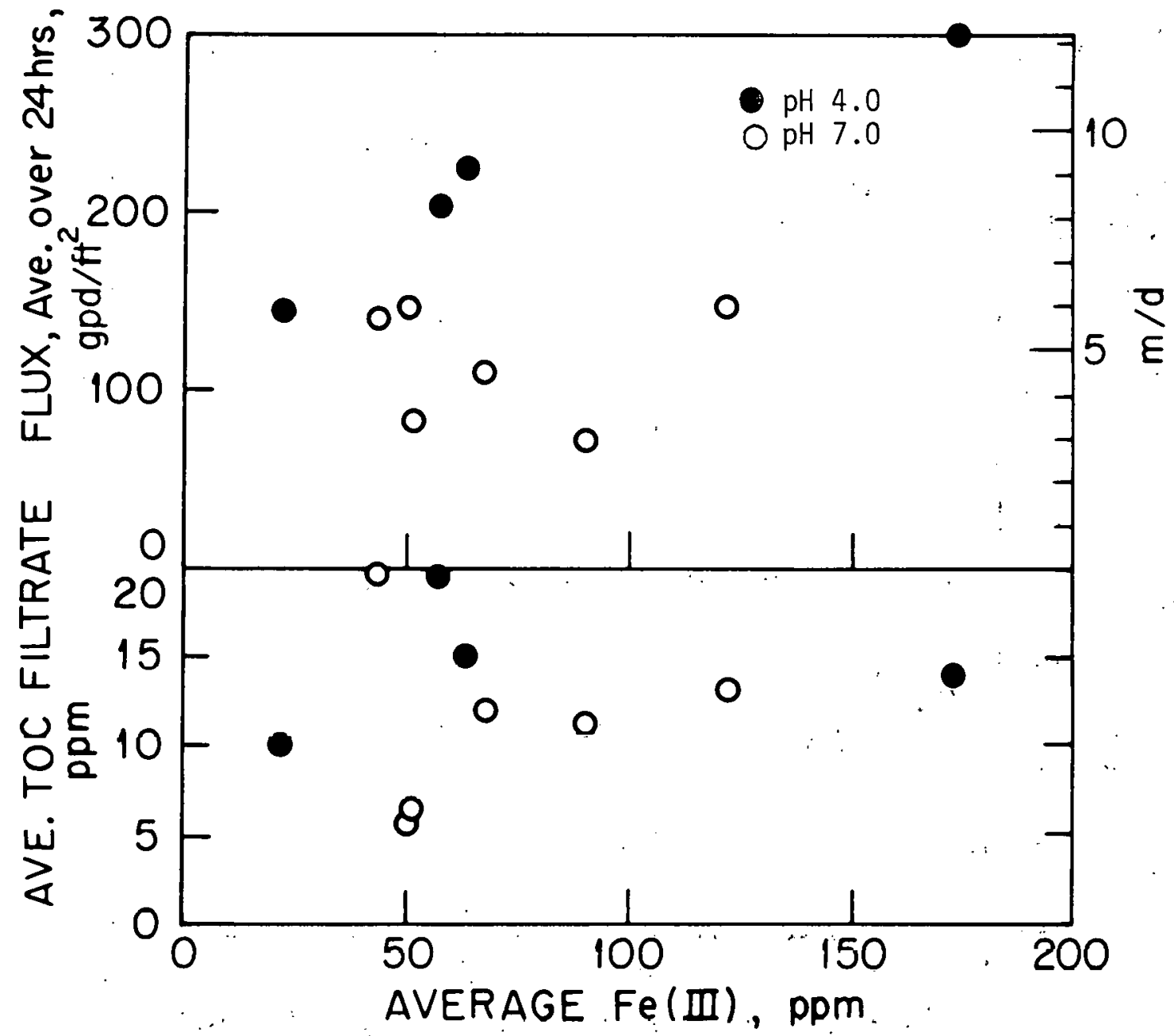

Fig. 32. Correlation of flux and filtrate quality with Fe(III) addition. (Fire-hose jacket, external flow; 40 psi [2.8 bar] at inlet; $15 \mathrm{ft} / \mathrm{sec}[4.6 \mathrm{~m} / \mathrm{sec}])$ 


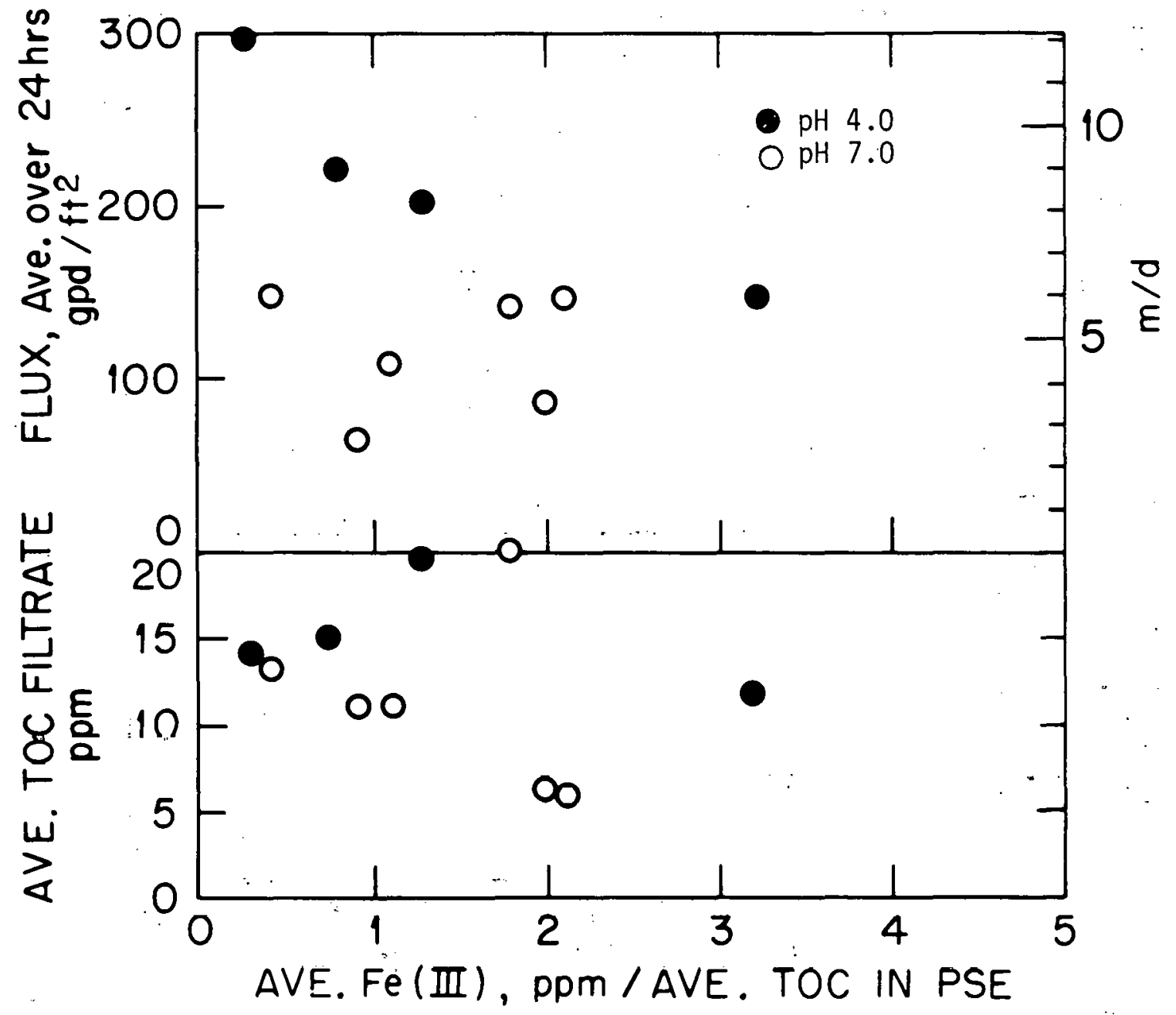

Fig. 33. Correlation of flux and filtrate quality with Fe(III) and organic carbon in primary sewage. 
the $\mathrm{pH}$ range of the first set (including results at the ORNL plant in Figs. 18-21) have been more consistent with those of Fig. 32 than with Fig. 27. Average operating temperatures of the lower-flux set were sligitly higher than with the other, the wrong direction to explair the discrepancy.

One difference in operation was that the liquid. level maintained in the feed tank was lower in the set of higher flux (Fig. 27) and there consequently was considerable foaming; conceivably flux-limiting constituents could have been extracted in the foam. However, in a later test carried out under similar conditions, with foam removed, the flux was lower than in either set, about $10 \mathrm{~m} / \mathrm{d}\left(250 \mathrm{gpd} / \mathrm{ft}^{2}\right)$ at 2 hours. It is perhaps worth noting that the foam did concentrate constituents; foam collected over the first eight hours of operation contained $530 \mathrm{mg} / \mathrm{l}$ TOC and $355 \mathrm{mg} / \mathrm{l} \mathrm{Fe}$ (III), and over the last two hours, $480 \mathrm{mg} / \mathrm{l}$ TOC and $600 \mathrm{mg} / \ell \mathrm{F}$. (III); for comparison, the circulating concentrated solution contained $180 \mathrm{mg} / \ell$ TOC and $170 \mathrm{mg} / \ell \mathrm{Fe}($ III) at termination of the experiment .

In this connection, we carried out a pH scan by base and acid additions after overnight operation at $\mathrm{pH} \sim 6$. The results (Fig. 34) indicate no strong effect of acidity on flux, at least with this presumably stabilized filtercake. In Fig. 35, the early stage of this run is compared with the same stage of the subsequent run, for which the conditions were similar, except that $\mathrm{pH}$ of operation was about 7 . Fluxes were very similar, differences becoming apparent only after increase of water recovery was started in the first run by discarding filtrate (the $\mathrm{pH} 6$ results in this figure were also included in Fig. 14.)

The relative independence of flux on $\mathrm{pH}$ is contrary to preliminary observations reported previously, 35 in which fluxes increased sharply with increasing $\mathrm{pH}$. We later found that when the results in Fig. 6.23 of Ref. 35 were obtained feeds were contaminated with copper, sometimes tens of ppm, coming from copper cooling coils in the feed tank during exposure to acidic solutions in the initial addition of ferric salts. Since this pattern of flux dependence on $\mathrm{pH}$ disappeared when the acid part of the cycle was relocated to stainless steel tanks, we attribute it to copper contamination. The copper cooling coils were replaced. 


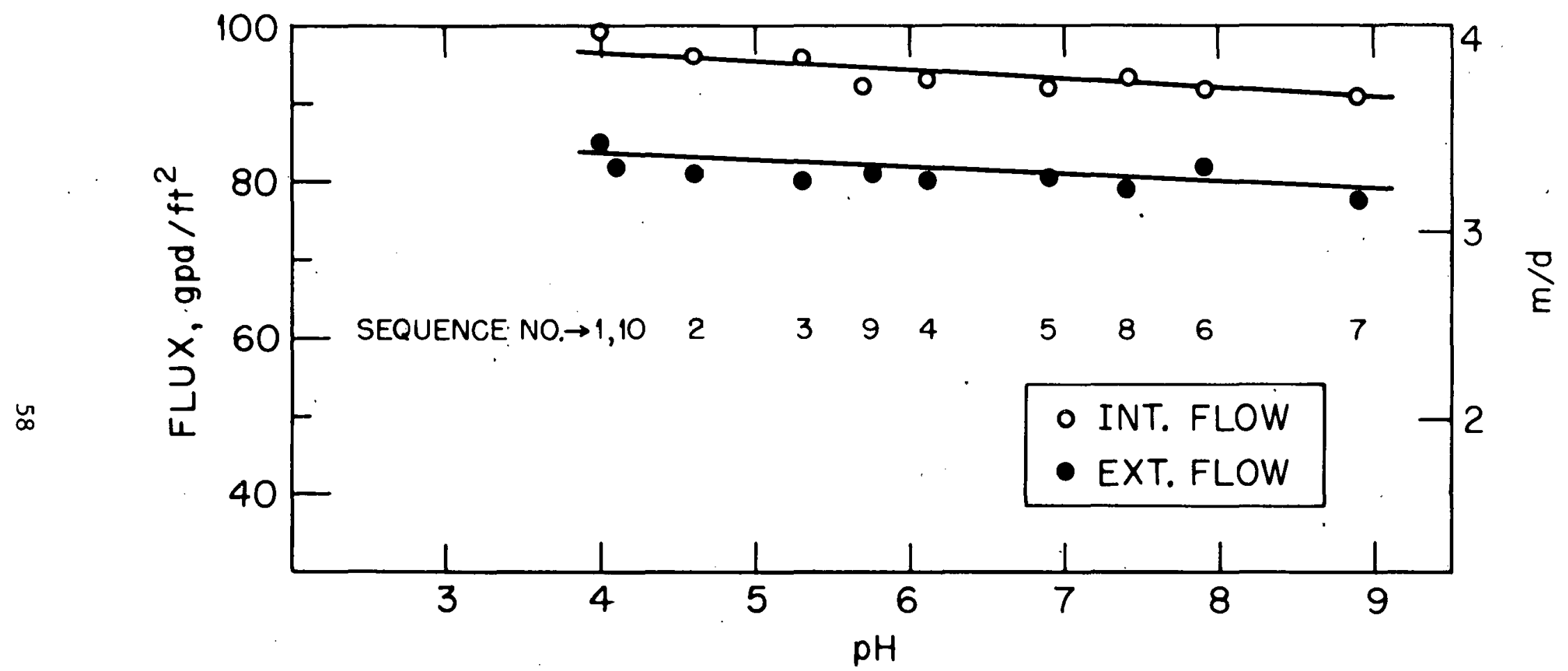

Fig. 34. Effect of zcidity on cross-flow filtration flux.

(Primary sewage, 55 ppm $\mathrm{Fe}$ (III); inlet pressure 40 psi [2.8 bar];

$\sim 15 \mathrm{ft} / \mathrm{sec}[\sim 4.6 \mathrm{~m} / \mathrm{sec}] ; 66 \%$ water recovery; measurements between 21 and 26 hours from start) 


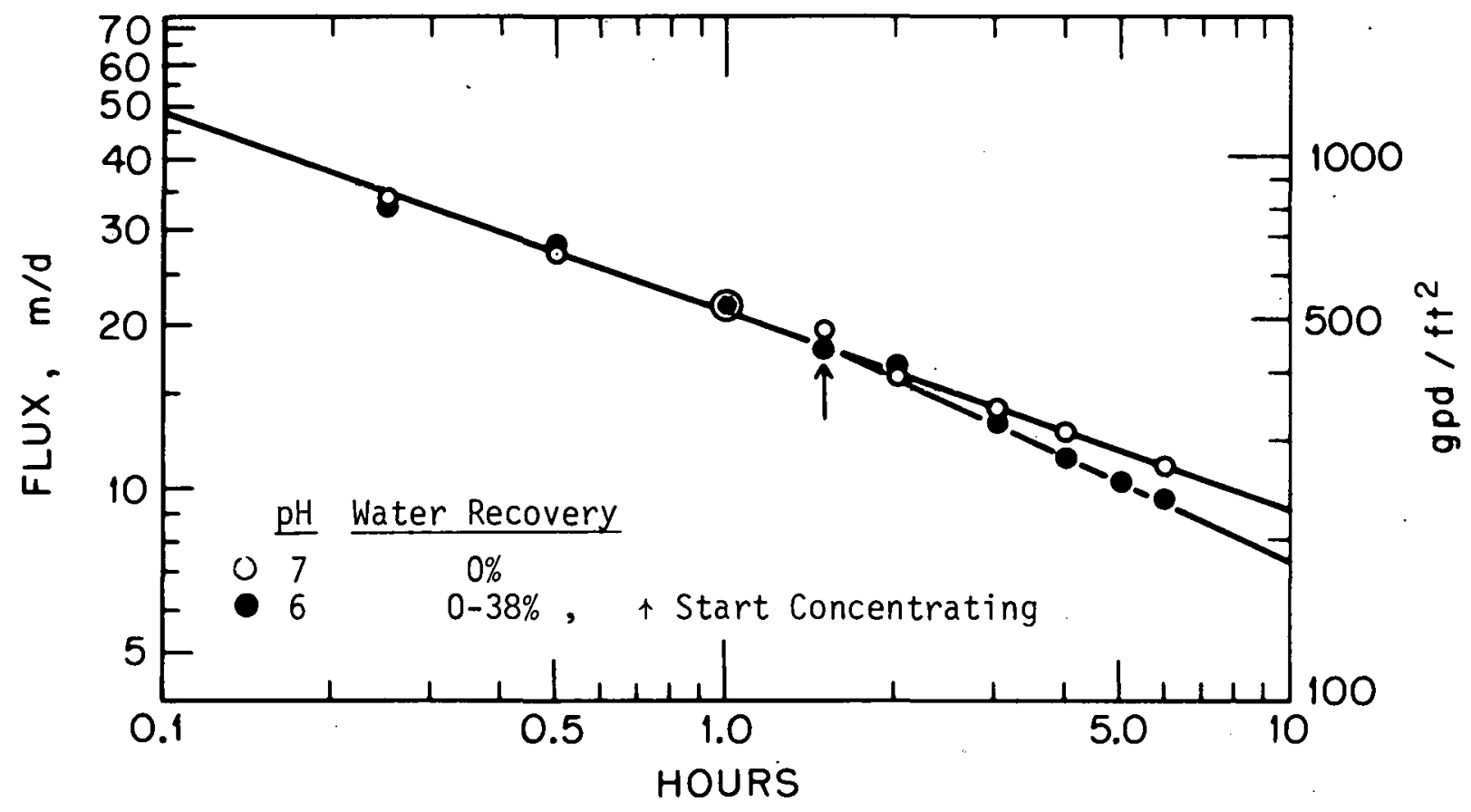

Fig. 35. Comparison of initial fluxes in operation at pH 6 and $\mathrm{pH} 7$. (Primary sewage; fire-hose jackets, ext. flow; $50 \mathrm{ppm}$ iron, introduced as ferrous sulfate; 40 psi [2.8 bar]; $15 \mathrm{ft} / \mathrm{sec}[4.6 \mathrm{~m} / \mathrm{sec}] ; 30^{\circ} \mathrm{C}$ ) 
With respect to differences in the sets reported in Figs. 27 and 32, we can advance only the unsatisfying suggestion that there was an unknown difference in the composition of the sewage effluents during the periods of the measurements.

We have carried out a similar, though less extensive, study with A1(III). The results are summarized in Figs. 36-38. (Since the atomic weight of aluminum is about half that of iron, the molar Al(III) concentration corresponding to a given ppm of Al(III) will be about the same as the molar concentration of $\mathrm{Fe}$ (III) at twice the ppm.) There appears to be a trend to higher fluxes with increasing Al(III) concentration, but the scatter is so large that a definite conclusion is not possible on the basis of the few runs here.: Fluxes are closer to those reported. in the second set with Fe(III), presented in Fig. 32, than to the other set (Fig. 27).

Use of Lime for Neutralization

Per equivalent of base, $\mathrm{CaO}$ is much cheaper than $\mathrm{NaOH}$, and if there is no penalty in performance, it would presumably be the choice for adjusting sewage treated with hydrolyzable ions to the $\mathrm{pH}$ selected for filtration. Most of our experiments were carried out with $\mathrm{NaOH}$, since we had no equipment for automatic addition of solids, necessary for unattended overnight operation, unless filtrates were recycled to the feed tank ( $0 \%$ water recovery). However, several short-term runs allow a comparison between fluxes obtained successively with $\mathrm{NaOH}$ and with $\mathrm{CaO}$ neutralization (Table 3).

Scatter was great, but there appears to be no consistent flux advantage from the use of one base or the other. There was an indication that fluxes after lime neutralization were higher when the other reagents were. added as chlorides, rather than as sulfates. Simultaneous runs were made with the two loops in the mobile unit to check this point with two batches of primary effluent taken at the same time, one treated with chloride and one with sulfate reagents (Fig. 39). There did not appear to be any significant differences in flux, and it appears the variations in Table 3 resulted from random day-to-day changes in sewage. We conclude tentatively that performance after neutralization with $\mathrm{CaO}$ is as satisfactory as after neutralization with $\mathrm{NaOH}$. 
Table 3. COMPARISON OF FLUXES AFTER NEUTRALIZATION

BY NaOH AND BY CaO

(40 psi $\left.\left[275,000 \mathrm{~N} / \mathrm{m}^{2}\right] ; 15 \mathrm{ft} / \mathrm{sec}[4.6 \mathrm{~m} / \mathrm{sec}]\right)$

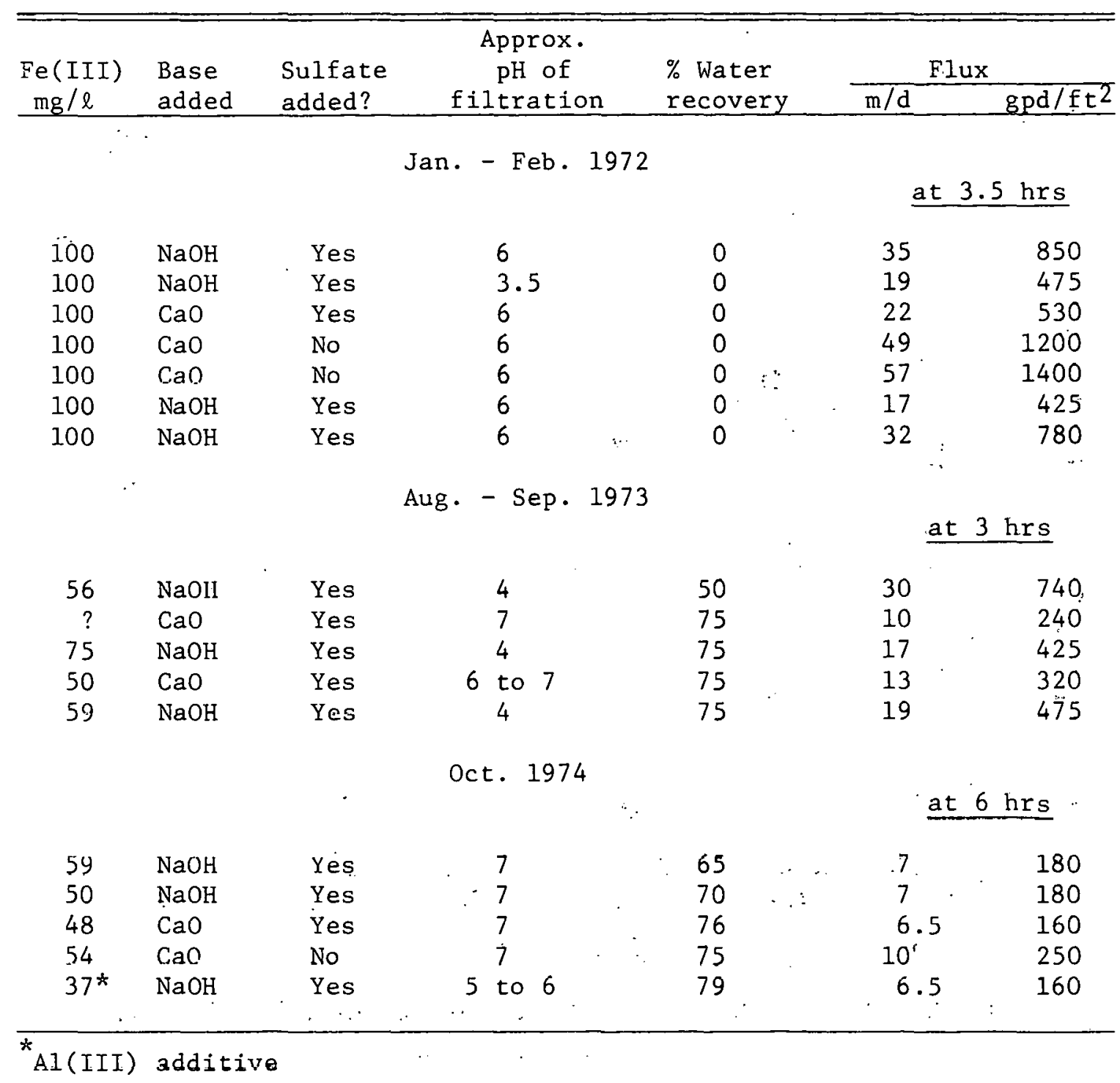




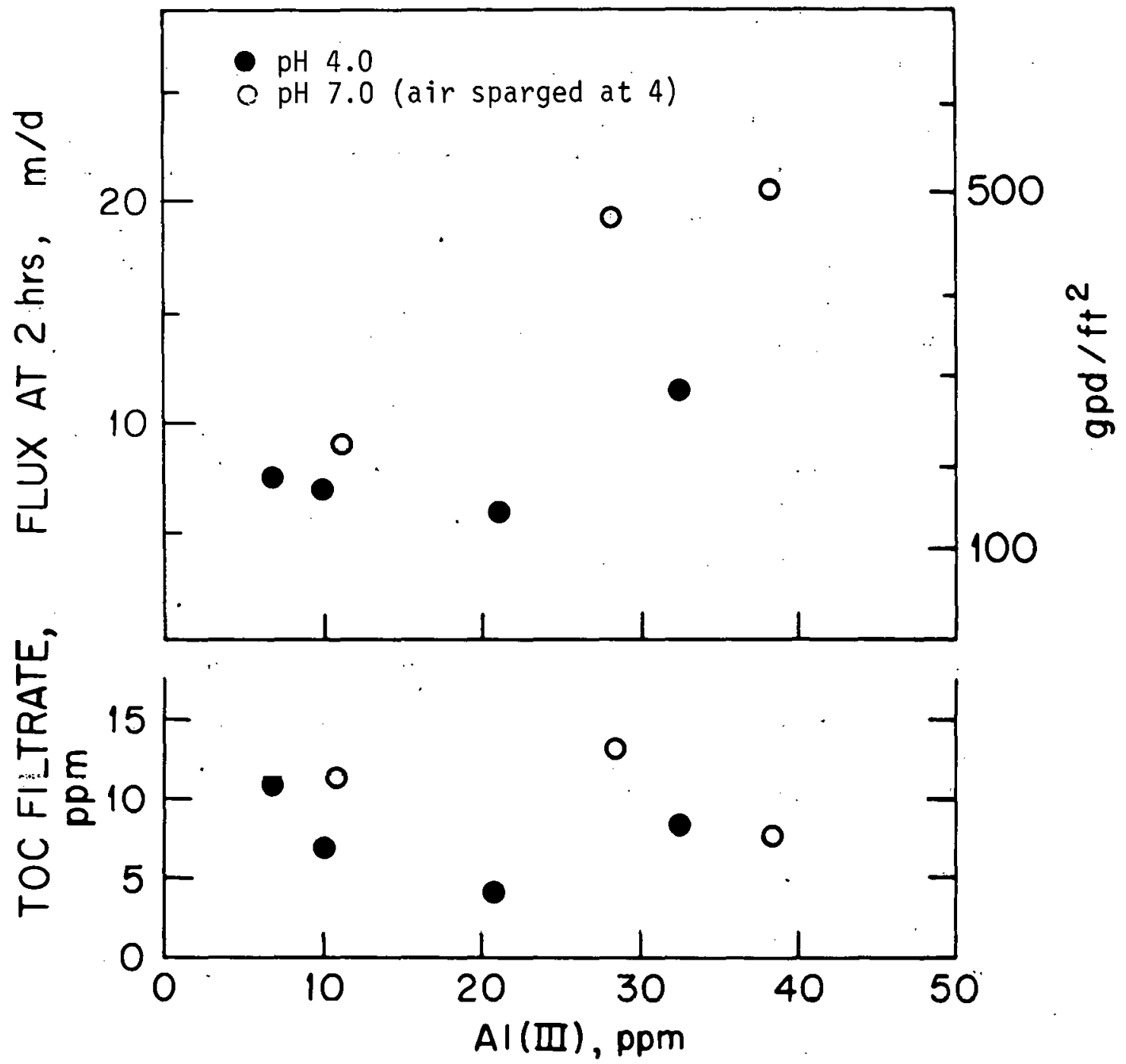

Fig. 36. Flux at two hours as function of $A 7$ (III) addition. (TOC measured at $3 \mathrm{hrs}$ ) 


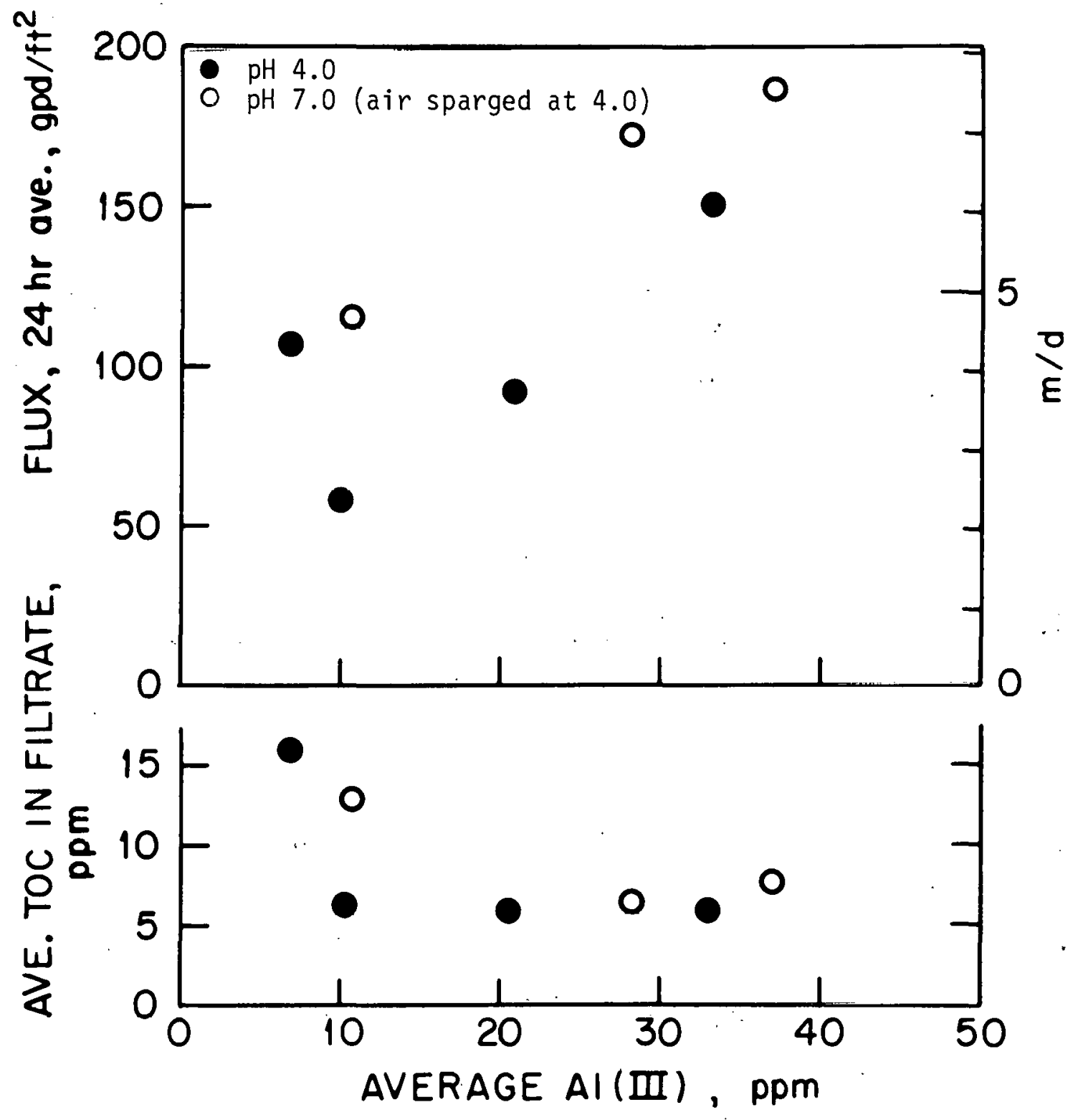

Fig. 37. Flux and filtrate quality with Al(III) addition to primary sewage. 


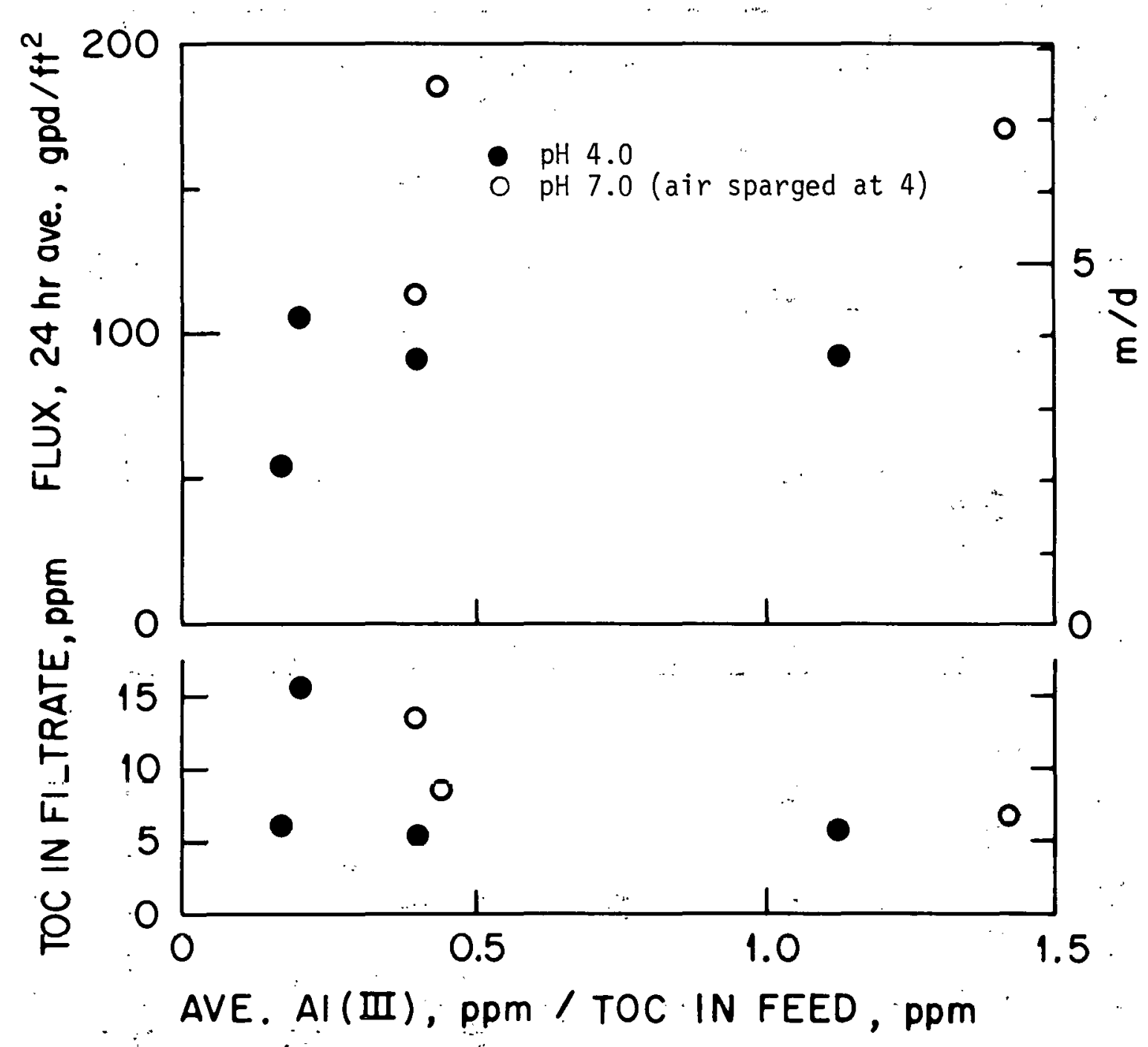

Fig. 38. Flux and filtrate quality as function of $\mathrm{ppm} A T$ (III) addition per ppm TOC in primary sewage. 


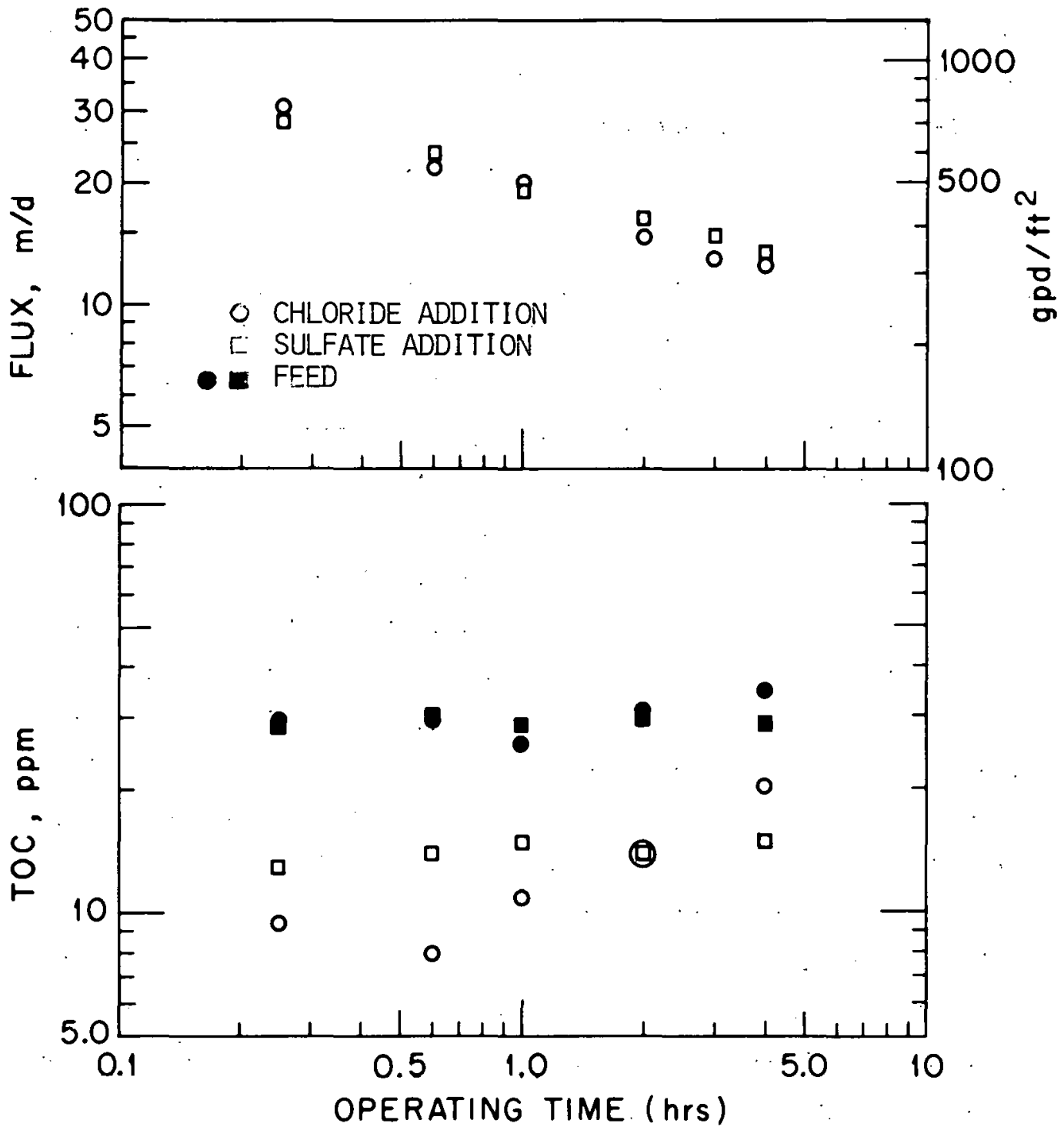

Fig: 39. Comparison of cross-flow filtration of primary sewage neutralized with $\mathrm{CaO}$ after addition of iron sulfate and iron chloride.

$\left(\mathrm{pH} 7.5-8 ; 30^{\circ} \mathrm{C} ; 40 \mathrm{psi}[2.8 \mathrm{bar}] ; 15 \mathrm{ft} / \mathrm{sec}[4.6 \mathrm{~m} / \mathrm{sec}] ;\right.$ fire-hose jackets; external flow; $0 \%$ water recovery) 
Quality of Cross-Flow Filtrates from Effluents Treated with

Hydrolyzable Ions

Filtrate and primary sewage were sampled for analysis at irregular intervals of a few hours, mostly during the normal work day. Analyses of filtrates taken during evening and nights were relatively rare; those available from off-hours did not appear to depart greatly from the pattern reported here.

TOC - Typical total organic carbon in filtrates of feed treated with $\mathrm{Fe}$ (III) or $\mathrm{Al}$ (III) are recorded in Figs. 27, 32, and 37. From these and other results, it appears that with primary effluent as feed, TOC can be reduced most of the time to $10-15 \mathrm{mg} / \mathrm{l}$ by this treatment. Over the range studied, there does not seem to be much influence of additive concentration on product quality in this respect.

Removal of TOC by cross-flow filtration appears to be somewhat higher than by the activated sludge secondary treatment of the Oak Ridge Municipal Plant. For twenty-five runs in the period January through April 1972, mostly with $\mathrm{Fe}$ (III)-treated primary effluent feed, a comparison was made between TOC of filtrate from cross-flow filtration and effluent from secondary settler of the municipal plant. The secondary effluent was sampled about 7 hours after start of filtration, to allow roughly for hold-up time in the activated sludge system. The average value for cross-flow filtrate was $11.3 \mathrm{mg} / \mathrm{l}$, with a range of 4 to 20 , and for the effluent from biological treatment, 14.4, with a range of 7 to 34 . Average primary effluent was $47.2 \mathrm{mg} / \mathrm{l}$ and removal of organic carbon from primary sewage was $76 \%$ by cross-flow filtration, in comparison with $69 \%$ by the standard secondary treatment. This comparison should be viewed with some caution. A wide range of variables was tested in the filtration runs, and the average thus may not represent performance under optimal conditions. On the other hand, most of these experiments were short-term, with filtrate returned to the feed tank (0\% water recovery). However, the results are in the range of other values in this study, and we believe the comparison is meaningful.

In this connection, we note that TOC content of the filtrate seems generally not to vary significantly with water recovery, i.e., the 
percentage removal of TOC increases with TOC content. of the concentrating solution being filtered. This may imply that there is a certain fraction of original TOC completely removed, and a fraction, presumably of low molecular size and non-adsorbable on hydrous oxides, which passes through completely with the water. Examples of filtrate TOC during increasing recovery can be seen in Figs. 45-47, to be discussed later.

We pointed out in connection with Fig. 27 that cross-flow filtrates from secondary effluent treated with $\mathrm{Fe}$ (III) were usually lower, in the neighborhood of 5 ppm in TOC, than when primary effluent was the feed. Turbidity - Turbidities of filtrates after the first few minutes of operation were usually well below 1 JTU, there being for example no values above this and only three observations above $0.5 \mathrm{JTU}$ in twenty-four runs during the period the results of Fig. 26 to 32 were obtained. Filtrates usually were visually similar to tap water. Primary effluent turbidities varied between 10 and $100 \mathrm{JTU}$.

Phosphate - With sufficient $\mathrm{Fe}$ (III), removal of phosphate is usually good. In the runs of Fig. 26, in only one analyzed sample was total phosphate (as $\mathrm{PO}_{4}^{3-}$ ) as high as $0.3 \mathrm{mg} / \mathrm{l}$. In the runs of $\mathrm{Fig} .32$, removal for some runs was poorer in several cases; filtrate samples in three runs contained over $1 \mathrm{mg} / \ell$ phosphate. In one case of low $\mathrm{Fe}(21 \mathrm{ppm})$ and high average molar ratio of feed phosphate to iron (1.25), there were $2.4 \mathrm{mg} / \ell$ in the filtrate. In the six other runs, all samples were well below $1 \mathrm{mg} / \mathrm{l}$ phosphate.

With $\mathrm{Al}$ (II) additions, phosphate removal was sensitive to $\mathrm{pH}$. At $\mathrm{pH}$ values below 5 , several $\mathrm{mg} / \ell$ of phosphate was found in filtrates, as high as $40 \mathrm{mg} / \ell$ in one case. Above $\mathrm{pH}$ 6, phosphate removals were comparable to the results with $\mathrm{Fe}$ (III) treatment, the content usually being well below $1 \mathrm{mg} / \ell$.

Contamination of filtrates by hydrolyzable ion additions - We mentioned earlier that, at low $\mathrm{pH}$, the filtrate contains iron; probably most penetrating the filter is $\mathrm{Fe}(\mathrm{II})$, remaining despite air-sparging in pretreatment. Ferrous would be expected to penetrate more than Fe(III), since it is less acidic, and therefore at a given $\mathrm{pH}$ tends less than ferric to hydrolyze and form polymers and hydrous oxides. Iron removal will depend 
both on the equilibrium between $F e($ II) and Fe(III) species and the kinetics of reactions for reaching equilibrium and for hydrolysis of the ferric. On account of hydrolysis, the equilibrium for $\mathrm{Fe}$ (II)-Fe(III) shifts toward $\mathrm{Fe}$ (III) with increasing $\mathrm{pH}$, and one expects iron removal to increase with increasing $\mathrm{pH}$.

The effect of acidity is illustrated in a run in which $\mathrm{pH}$ was cycled from 3.5 to 10 and back to 4, with changes at one-hour intervals; the points represent analyses of samples taken just before $\mathrm{pH}$ adjustments (Fig. 40). Primary effluent was brought to $100 \mathrm{ppm} \mathrm{Fe(III)} \mathrm{and}$ $\mathrm{pH} 3$, digested overnight, and the $\mathrm{pH}$ was brought to 3.5 just before starting the run. The analyses in the figure were from a fire-hose jacket, operated with external flow of $6.4 \mathrm{~m} / \mathrm{sec}(21 \mathrm{ft} / \mathrm{sec})$, with filtrate recycled to the feed tank ( $0 \%$ water recovery). Total iron in the filtrate decreased with increasing $\mathrm{pH}$, falling to $0.1 \mathrm{mg} / \ell$ or less at $\mathrm{pH}$ of 6 and higher. However, (point 8) reversal of the metal ion oxidation was illustrated by the fact that the filtrate again contained iron when $\mathrm{pH}$ was decreased to 4 . On return to low $\mathrm{pH}$ slightly less than half the iron penetrating the filter was Fe(II); in all other cases, $\mathrm{Fe}$ (II) accounted for all but perhaps $1 \mathrm{mg} / \ell$ of the iron in filtrates. Phosphate was also somewhat more completely filtered at higher pH. Filtrate TOC scattered between 4 and $8 \mathrm{mg} / \ell$, with perhaps slightly better removal at high $\mathrm{pH}$.

In nineteen of the experiments of Figs. 27 and 32 utilizing primary effluent, the following iron contents were obtained:

$$
\mathrm{pH}
$$

$\mathrm{pH}$

$\mathrm{mg} / \mathrm{l} \mathrm{Fe}$ in filtrate

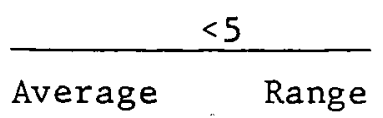

3. $9-5$

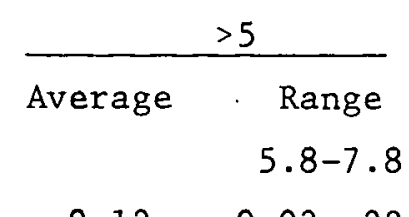

3.6

0.12

$0.03-.22$

In steady-state operation at $\mathrm{pH}>6$ with added iron salts, iron contamination of treated water will probably be acceptable for most situations. If the additive is introduced as $\mathrm{Fe}$ (II), however, which may be desirable because of the solubility of ferrous sulfate in comparison with ferric sulfate, and the corrosiveness of chlorides, the kinetics of transformation to ferric becomes of concern. In experiments at the ORNL 


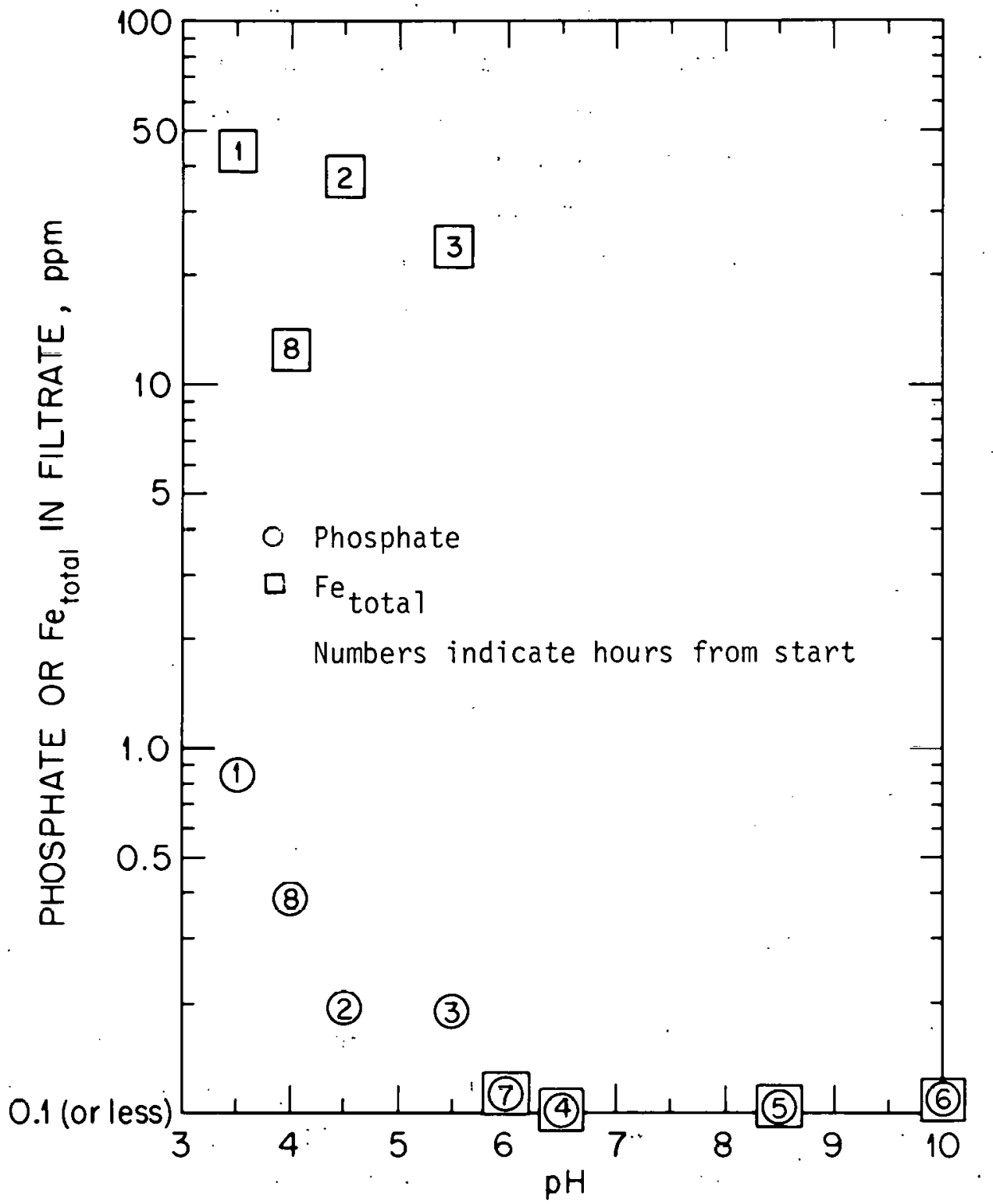

Fig. 40. Phosphate and metal ion leakage in cross-flow filtration of primary sewage as a function of . $\mathrm{pH}$.

(40 psi [2.8 bar]; fire-liuse jackels) 
pilot plant, in which the additive was $\mathrm{FeSO}_{4}$, iron contamination of the filtrate of several ppm has occurred, even in high $\mathrm{pH}$ operation. In these cases, the base to neutralize the feed was added in the tanks from which the pump circulates it past the filters. Since filtrate contamination was highest when production rate was high and fresh feed was drawn into the feed tanks at frequent intervals, it seems clear that limited time for the oxidation of $\mathrm{Fe}(\mathrm{II})$ is responsible.

The time necessary for oxidation of iron introduced as Fe(II) salts to $\mathrm{Fe}$ (III) will depend of course on conditions affecting kinetics, such as mixing and especially acidity. In one experiment, carried out at $\mathrm{pH} 6$ in the mobile unit at the municipal sewage plant, iron was essentially undetectable in the filtrate in the first analysis, on a sample taken after about two hours operation. In another, (also discussed in connection with Figs. 14 and 35), however (Fig. 41), the filtrate contained several mg/l even after 6 hours operation, although levels were low the next day. At higher $\mathrm{pH}$, presumably because of faster oxidation and hydrolysis, good removals occurred much earlier. In Figure 42, Fe in filtrate from one of the test sections of Fig. 41 is compared with Fe in filtrate obtained in another experiment, similar except that $\mathrm{pH}$ was 7 .

Contamination of filtrate with iron even when added as ferrous can therefore be avoided with short holdup time, if $\mathrm{pH}$ during filtration is high enough. However, higher base additions are necessary. For example, in the run at $\mathrm{pH} 7$ of Fig. 42 about 1.3 millimoles of $\mathrm{H}_{2} \mathrm{SO}_{4}$ per 1 iter of primary effluent were used, in addition to ferrous sulfate, to bring the sewage initially to $\mathrm{pH} 4 ; 1.6$ millimoles of $\mathrm{NaOH}$ per liter brought the $\mathrm{pH}$ back to 6 and an additional 1.7 millimoles/liter to $\mathrm{pH} 7$.

$\mathrm{Al}$ (III) was also high in the filtrate in operation at low $\mathrm{pH}$. To cite extremes, in one run at $\mathrm{pH} \sim 4$, with average $\mathrm{AL}$ (III) addition of $32 \mathrm{mg} / \mathrm{l}, 25 \mathrm{mg} / \mathrm{Al}$ (III) was found in the filtrate; in another run at $\mathrm{pH} 7.8, \mathrm{Al}$ (III) was $0.01 \mathrm{mg} / \mathrm{l}$. For the runs for Fig. 37, with one exception (a value of $1.5 \mathrm{mg} / \mathrm{l} \mathrm{Al}$ (III) at $\mathrm{pH} 7.5$ ), $\mathrm{Al}$ (III) in the filtrate was less than $1 \mathrm{mg} / \ell$ at $\mathrm{pH}>5$, and was several $\mathrm{mg} / \ell$ at $\mathrm{pH}<5$. 


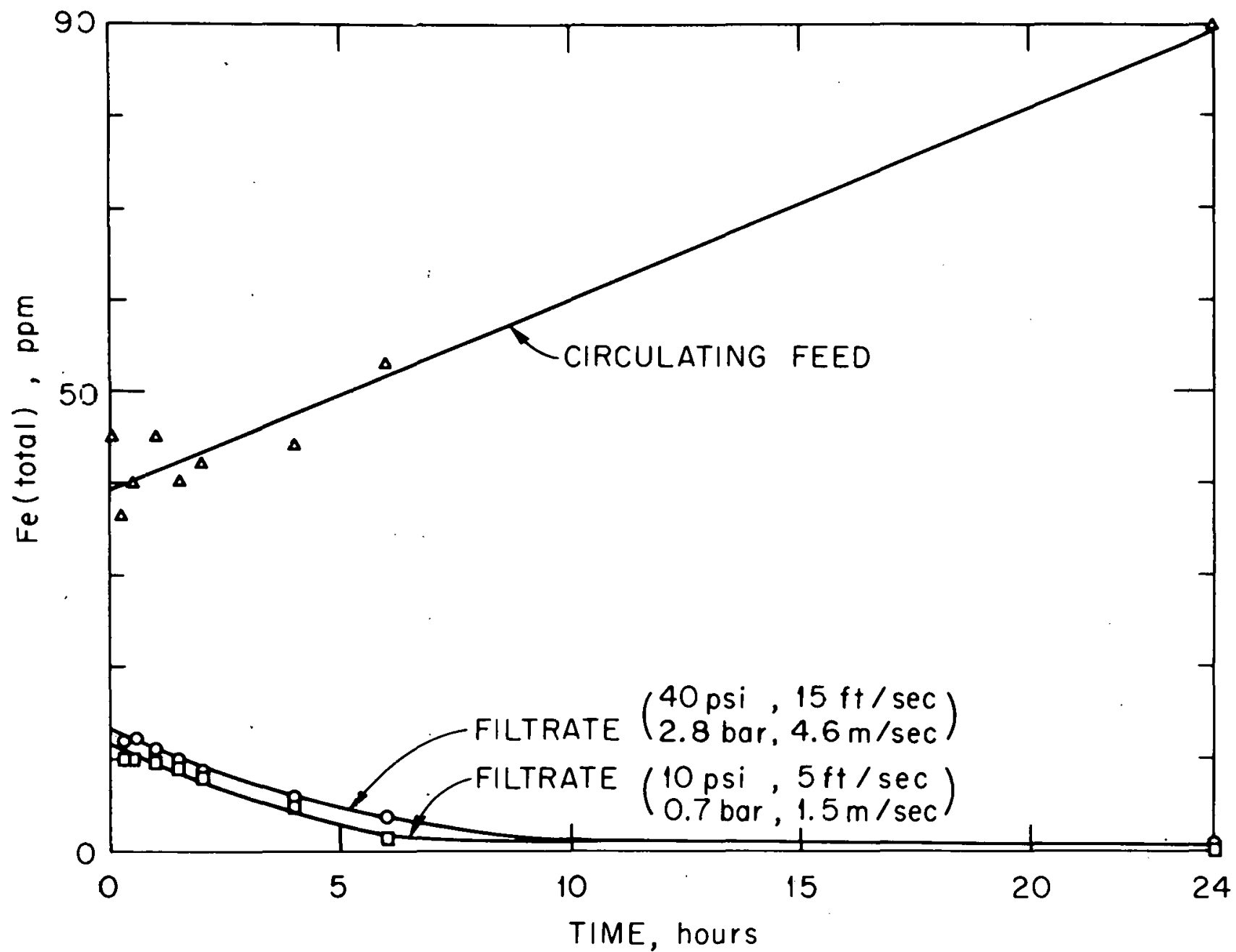

Fig. 41. Filtration of Fe(total) with time, after introduction as Fe(II). $(\mathrm{pH}$ б) 


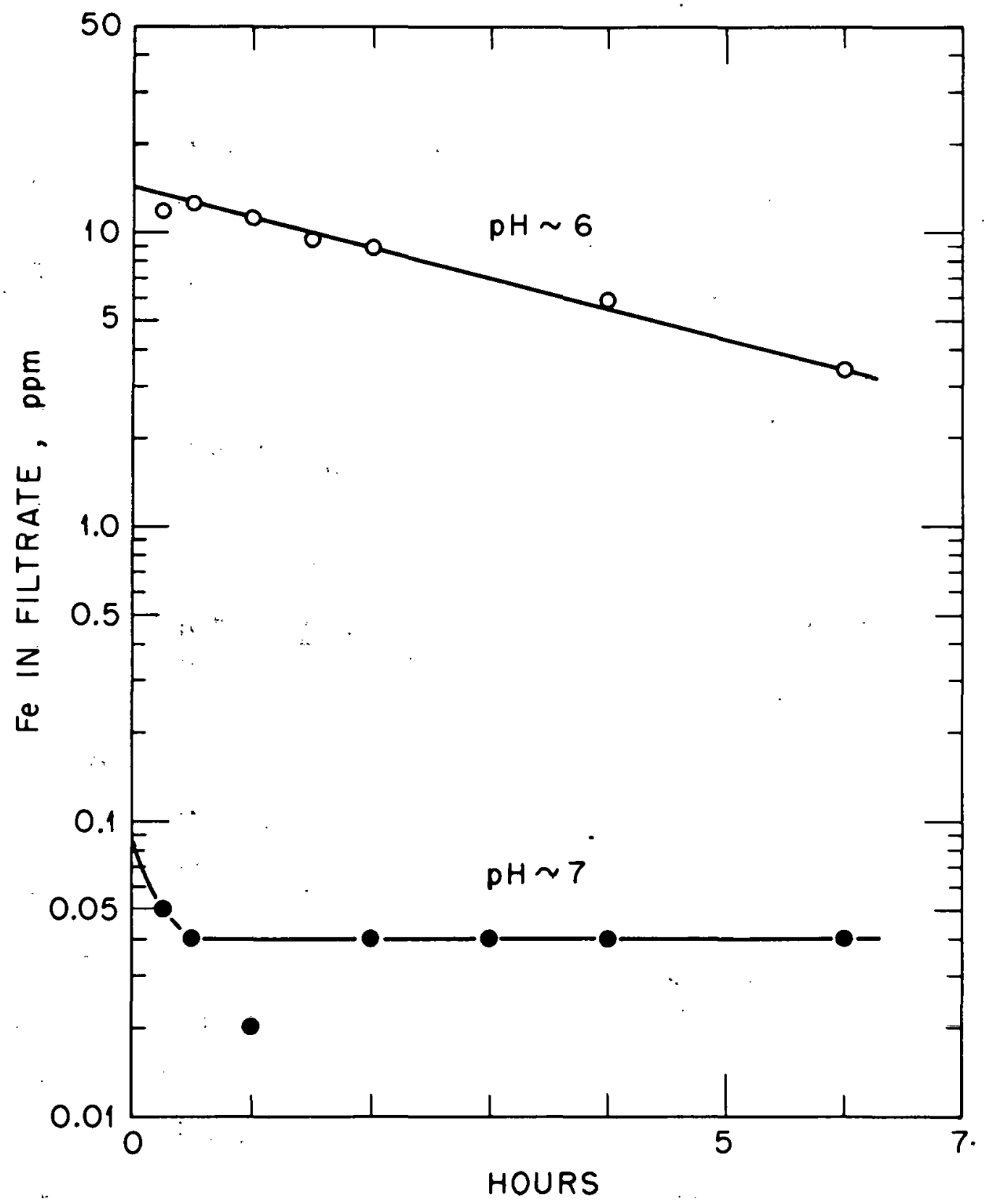

Fig. 42. Iron contamination of filtrate as a function of acidity. (50 ppm $\mathrm{Fe}$, introduced as $\mathrm{Fe}(\mathrm{II})$ sulfate; $15 \mathrm{ft} / \mathrm{sec}[4.6 \mathrm{~m} / \mathrm{sec}$ ]; 40 psi $[2.8$ bar $] ; 30^{\circ} \mathrm{C}$ ) 
Nitrogen compounds - We have accumulated little information on the removal of nitrogen compounds by cross-flow filtration of sewage effluents.

In one experiment, with $100 \mathrm{mg} / 2 \mathrm{Fe}$ (III) added to primary effluent from the Oak Ridge Municipal plant, followed by digestion at $\mathrm{pH} \sim 3$ and adjustment to pH.6 for filtration, analyses for organic nitrogen were carried out by personnel of the Environmental Engineering Department of the University of Tennessee, Knoxville (we are indebted to Prof. W. A. Drewry for arranging these). Their results indicated $5.6 \mathrm{mg} / \mathrm{l}$ as $\mathrm{N}$ in primary sewage, and only a trace in the cross-flow filtrate. A sample of secondary effluent from activated sludge treatment taken the same day contained $0.6 \mathrm{mg} / \mathrm{l} \mathrm{N}$. They also carried out chemical oxygen demand analyses on the same samples and reported: primary, $136 \mathrm{mg} / \mathrm{l}$; cross-flow.filtrate, 8; and secondary sewage, 56. Our corresponding TOC analyses were primary, $53 \mathrm{mg} / \mathrm{l}$; filtrate, 10 ; and secondary sewage, 26.

We analyzed samples for three.cross-flow filtrations of effluents from activated sludge treatment and one from primary effluent for total nitrogen. Results are summarized in Table 4.

Table 4. NITROGEN REMOVAL IN CROSS-FLOW FILTRATION $(\mathrm{pH} \sim 4)$

\begin{tabular}{|c|c|c|c|c|c|c|}
\hline \multirow[b]{3}{*}{$\begin{array}{c}\mathrm{Fe}(\mathrm{III}) \\
\mathrm{mg} / \mathrm{l}\end{array}$} & \multirow[b]{3}{*}{$\begin{array}{l}\text { Time from } \\
\text { start, hrs. }\end{array}$} & \multirow[b]{3}{*}{$\begin{array}{l}\text { Water } \\
\text { rec. } \%\end{array}$} & \multicolumn{4}{|c|}{ Total nitrogen, $\mathrm{mg} / \mathrm{l}^{\star}$} \\
\hline & & & \multirow[b]{2}{*}{ Feed } & \multirow[b]{2}{*}{$\begin{array}{l}\text { Circulating } \\
\text { concentrate }\end{array}$} & \multicolumn{2}{|c|}{ Filtrate } \\
\hline & & & & & $\begin{array}{l}\text { unlside } \\
\text { flow }\end{array}$ & $\begin{array}{c}\text { Instde } \\
\text { flow }\end{array}$ \\
\hline & - & & \multicolumn{4}{|c|}{ Secondary Sewage Feed } \\
\hline 77 & 3 & 80 & 0.5 & 1.0 & 0.35 & - \\
\hline 69 & 24 & 96 & 2.0 & 11.6 & 0.3 & 0.9 \\
\hline \multirow[t]{2}{*}{100} & 24 & 90 & 13 & 13 & 10 & 11 \\
\hline & & & \multicolumn{4}{|c|}{ Primary Sewdye Feed } \\
\hline 50 & 6 & 90 & 30 & 48 & 21 & 22 \\
\hline
\end{tabular}


In another experiment with primary effluent (other aspects were discussed in connection with Figures 14, 35, and 42) in which iron (about $50 \mathrm{mg} / \ell$ ) was introduced as $\mathrm{Fe}(\mathrm{II})$ and filtration was at $\mathrm{pH} \sim 6$, the average of analyses for primary was $20 \mathrm{mg} / \mathrm{l}$ total nitrogen (range 15 to 28) and 14 for filtrate (range 12 to 17), with little difference between the test sections, one operated at $4.6 \mathrm{~m} / \mathrm{sec}\left(15 \mathrm{ft} / \mathrm{sec}\right.$ ) at $276,000 \mathrm{~N} / \mathrm{m}^{2}$ (40 psi), and the other at $1.5 \mathrm{~m} / \mathrm{sec}(5 \mathrm{ft} / \mathrm{sec})$ at $69,000 \mathrm{~N} / \mathrm{m}^{2}$ (10 psi). Analyses of samples taken 22 hours after the start of the experiment to be discussed in connection with Fig. 44 with powdered activated carbon as additive, indicated essentially no removal--20 $\mathrm{mg}$ total $\mathrm{N}$ in both the primary effluent and in the filtrate.

No firm conclusions can be inferred from such scattered results. Removal of inorganic nitrogen compounds is, however, expected to be incomplete by either hydrolyzable ions or PAC additions; and if organic nitrogen is degraded to inorganic by biological action, higher percentage removals might be expected from primary effluents than from secondary. On the other hand, one might expect activated carbon to remove substantial fractions of organic nitrogen compounds, and the negligible reduction with primary effluent is surprising. With either type of additive, nitrogen removal appears erratic and incomplete.

Bacterial removal - The low turbidities of cross-flow filtrates suggest that particles of bacterial dimensions are removed, and limited analyses (carried out by the ORNL Industrial Hygiene Department) indicated that there probably are substantial reductions of organisms. However, many of the experiments were at low $\mathrm{pH}, 4$ to 4.5 , and the count in circulating concentrate was usually lower than with primary feed. This may result from carrying down of bacteria on hydrous oxide, but relative contributions of filtration and solution conditions unfavorable for organisms are not clearly distinguished. On the other hand, there was not sterilization of the filtrate side of the filter elements, and in some cases, sample bottles were not sterilized. It is possible that multiplication took place in the samples before assay. Table 5 summarizes some observations. 
Table 5. BACTERIA CONTENTS OF CROSS-FLOW FILTRATES

\begin{tabular}{|c|c|c|c|c|c|c|}
\hline \multirow[b]{3}{*}{$\begin{array}{l}\mathrm{Fe}(\mathrm{III}) \\
\mathrm{mg} / \ell\end{array}$} & \multirow[b]{3}{*}{$\begin{array}{l}\text { Time from } \\
\text { start,hrs. }\end{array}$} & \multirow[b]{3}{*}{$\begin{array}{l}\text { Water } \\
\text { rec., } \%\end{array}$} & \multicolumn{4}{|c|}{ Total coliform $/ \mathrm{ml}$} \\
\hline & & & \multirow[b]{2}{*}{$\begin{array}{l}\text { Primary } \\
\text { effluent }\end{array}$} & \multirow[b]{2}{*}{$\begin{array}{l}\text { Circulating } \\
\text { concentrate }\end{array}$} & \multicolumn{2}{|c|}{ Filtrate } \\
\hline & & & & & $\begin{array}{l}\text { outside } \\
\text { flow }\end{array}$ & $\begin{array}{l}\text { inside } \\
\text { flow }\end{array}$ \\
\hline & & & (pH 4 to & $4.5)$ & & \\
\hline 50 & 70 & 88 & TNTC & TNTC & $\begin{array}{l}0.4 \\
0.2\end{array}$ & - \\
\hline 50 & 6 & 90 & 1200 & 1 & 40 & $<1$ \\
\hline \multirow[t]{3}{*}{56} & 2 & 50 & $\begin{array}{l}12000 \\
17200^{*}\end{array}$ & $\begin{array}{l}120 \\
160^{*}\end{array}$ & $\begin{array}{l}<1 \\
<1^{*}\end{array}$ & $\begin{array}{l}<1 \\
<1^{*}\end{array}$ \\
\hline & & & & & \multicolumn{2}{|c|}{ Filtrate } \\
\hline & & & $(\mathrm{pH} \sim 6$ & & (botho & side) \\
\hline \multirow[t]{4}{*}{50} & 1 & 0 & & Neg & $\mathrm{Neg}$ & Neg \\
\hline & 2 & 8 & & 20 & $\mathrm{Neg}$ & $\mathrm{Neg}$ \\
\hline & 6 & 38 & & 20 & Neg & $\mathrm{Neg}$ \\
\hline & 24 & 62 & & TNTC & Neg & $\mathrm{Neg}$ \\
\hline
\end{tabular}

TNTC indicates Too Numerous To Count

* Total colonies/ml

The measurements at $\mathrm{pH} 6$ were all for a single run, for which the primary effluent feed count for coliform and for total colonies ranged from 2000 to TNTC per ml of primary (measurements on $1 \mathrm{ml}$ after 1 to 100 dilution). Prior to adjustment to $\mathrm{pH} 6$, the original feed har hepn. maintained at $\mathrm{pH} \sim 4$ with Fe(II) addition for about 45 minutes. Perhaps the exposure to acid conditions accounts for absence of detected bacteria Inftially and the low count the first day in the circulating concentrate. In any case, removal by filtration appears good (measurements on concentrate and filtrate on $1 \mathrm{~m} 2$ after 10 to 1 or 2 to 1 dilution).

Powdered Activated Carbon

Potential advantages of powdered activated carbon (PAC) over granular were alluded to in the Introduction, and have been discussed in greater length by Cohen. ${ }^{36}$ Our tests with primary sewage although less extensive than with jron salts, show that $\mathrm{P} \Lambda \mathrm{C}$ can be 
removed from sewage effluents essentially completely by cross-flow filtration; that, with sufficient PAC, high fluxes are achieved, and that the filtrate quality is good. Turbidity is low, and TOC is usually lower (typically about half) than in filtrate after Fe(III) or AI(III) additions to primary sewage. Phosphate is not removed well by PAC. Many other substances are adsorbed by powdered carbon, 37 though their removal was not evaluated in this study.

If satisfactory performance could be attained with powdered carbon additions so low that PAC regeneration was unnecessary, the mode would be particularly attractive. For reference, with $\mathrm{PAC}$ at $10 \mathrm{c} / \mathrm{lb}$ and with addition of $100 \mathrm{ppm}$ and throw-away operation, the activated carbon cost would.be about $8 \mathrm{c} / \mathrm{kgal}$. However, our experience indicates that, except in special situations, discard will likely be undesirably costly; fluxes at low levels of carbon are low.

It appears that the distribution coefficient for the solutes comprising the TOC in sewage effluents is not high enough for removal to low levels in the single-plate operation typical of powdered-carbon contacting, and rather large amounts of PAC are required per volume of effluent. Fig. 43 illustrates this with laboratory measurements of removal of TOC from the filtrate from cross-flow filtration, carried out at $\mathrm{pH} 6$, of primary effluent treated with $\mathrm{Fe}$ (III). It appears that reduction of TOC from $\sim 10 \mathrm{ppm}$ to $\sim 5 \mathrm{ppm}$ required about $1000 \mathrm{ppm}$ of $\cdot \mathrm{PAC}$. In the tests to be discussed, high ratios of PAC to feed or to the circulating concentrate were therefore maintained.

Fig. 44 illustrates typical behavior in cross-flow filtration of primary effluent with added powdered carbon. In this 14 -day run, $20 \mathrm{~g} / \mathrm{l}$ of PAC was added to the initial charge of primary effluent, and no more PAC was added as filtrate was discarded and fresh sewage brought in, until the last part of the run. The $\mathrm{pH}$ was adjusted to about 4 . Over the first day, during which enough primary passed through to bring the mg PAC/liter of sewage processed to about 500, average fluxes over 24 hours were $\sim 420$ gpd/ft ${ }^{2}$. Fluxes continued to decline, to below $25 \mathrm{gpd} / \mathrm{ft}^{2}$ after ten days, and a backwash caused only a momentary increase. However, a backwash coupled with addition of enough fresh PAC to bring the average PAC/ liter total sewage processed (filtrate plus concentrate) to $500 \mathrm{mg}$, about 


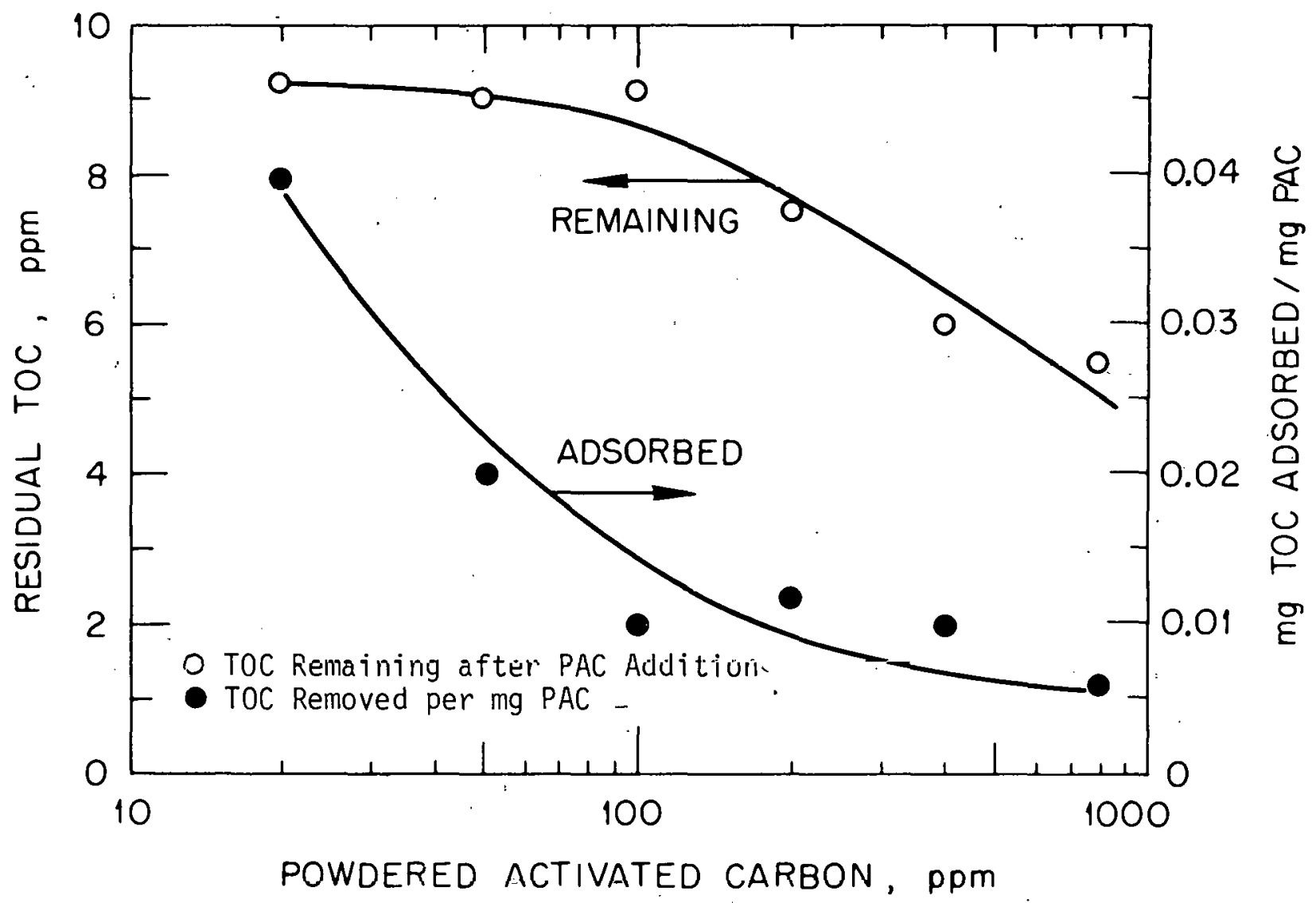

Fig. 43. Adsorption of TOC on PAC from cross-flow filtrate of $\mathrm{Fe}$ (III)-treated primary sewage. 


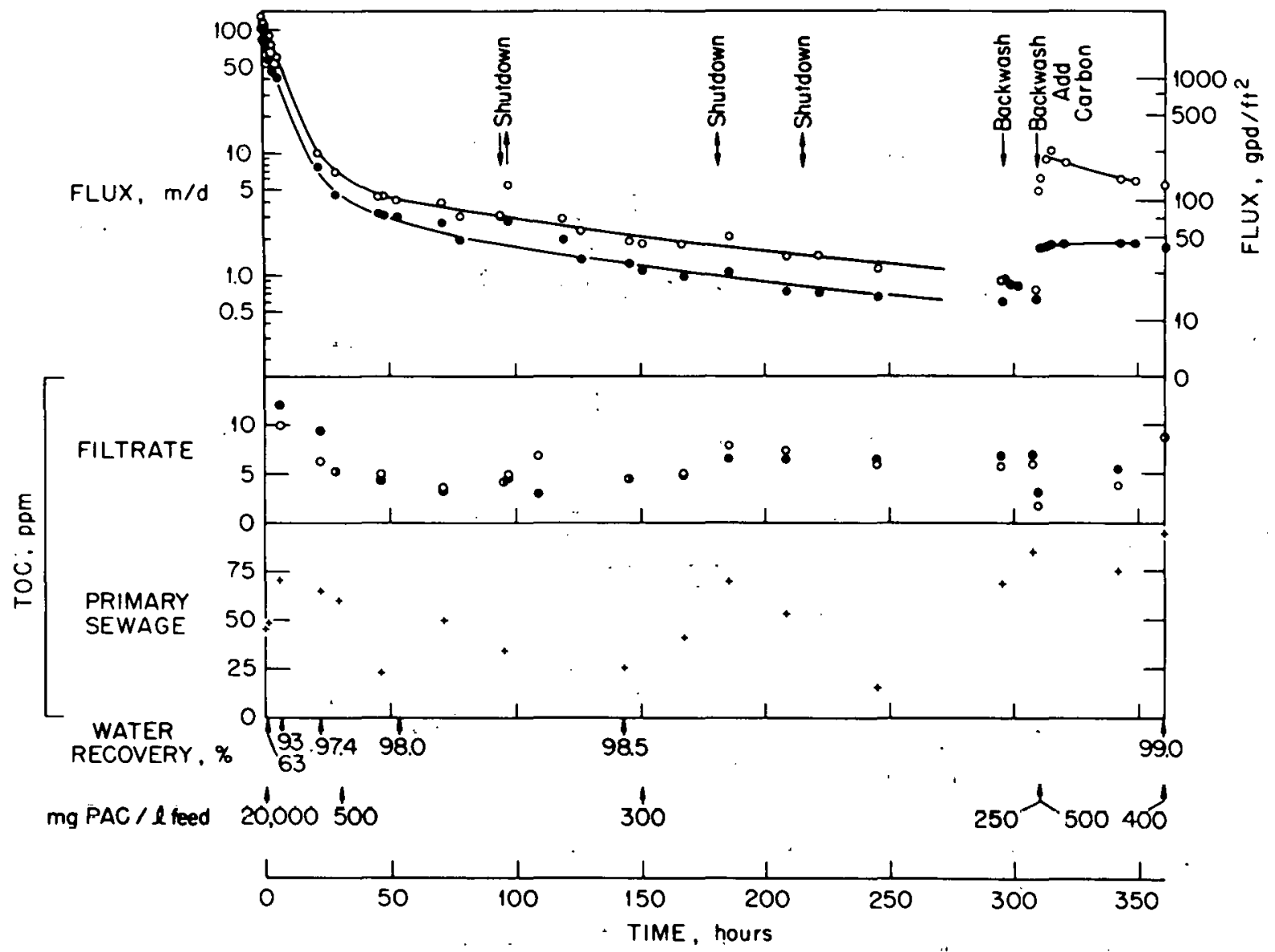

Fig. 44. Cross-flow filtration of primary sewage effluent after powdered carbon addition.

(Fire-hose jackets; external.flow, 40-37 psi [2.8-2.6 bar];

O internal flow, 40-7 psi [2.8-0.5 bar]; $15 \mathrm{ft} \mathrm{sec}[4.6 \mathrm{~m} / \mathrm{sec}]$ ) 
two days before termination, effected increase in flux to values in the ranges initially observed at the same PAC level.

Total organic carbon of the filtrate scattered about $5 \mathrm{ppm}$ after the first day. Phosphates were 20 to $30 \mathrm{ppm}$, comparable to concentrations of feed, and turbidities mostly $<0.5 \mathrm{JTU}$.

The results, particularly the flux recovery on addition of fresh carbon, suggest that maintenance of high fluxes requires a high enough $\mathrm{PAC} /$ feed ratio to tie up flux-limiting organic substituents. It should be noted that TOC in the filtrate does not completely define the level of non-adsorbed TOC in the circulating concentrate, since a thin layer of powdered carbon on the filter can provide in effect more than singleplate separation. 37

Two-Stage Processing by Hydrolyzable Ions Followed by PAC

Addition of PAC to the cross-flow filtrate from primary effluent treated with $\mathrm{Fe}$ (III) or $\mathrm{Al}$ (III), followed by a second-stage cross-flow filtration, should give a low-phosphate product. In addition, it might be hoped that fluxes high enough to make the second filtration cheap might be attained even at low PAC levels. Fig. 45 indicates that higher fluxes are obtained in a second stage than with primary sewage treated with a similar low level of PAC. After twenty-four hours operation ( $\mathrm{pH}>6$ in this and the two-stiage runs) at which time average PAC usage was about $65 \mathrm{mg} /$ liter filtrate, flux of the second stage had fallen to about $8 \mathrm{~m} / \mathrm{d}$ $\left(200 \mathrm{gpd} / \mathrm{ft}^{2}\right)\left(24-\mathrm{hr}\right.$ average $\left.\sim 12 \mathrm{~m} / \mathrm{d}\left(\sim 290 \mathrm{gpd} / \mathrm{ft}^{2}\right)\right)$, a reasonably high value, but not enough to make trivial the cost of the second stage. Phosphate in the first- and second-stage filtrates were $0.1 \mathrm{ppm}$ or less. Turbiditles of first-stage effluent were 0.3 to $0.4 \mathrm{JTU}$ and of second stage, $0.15 \mathrm{JTU}$.

In two other two-stage runs, initial additions of PAC to the first stage effluent were higher, and fluxes in the second stage were greater. Fluxes at 22 hours were in one about $20 \mathrm{~m} / \mathrm{d}\left(500 \mathrm{gpd} / \mathrm{ft}^{2}\right)$ at which time the average dosage was about $250 \mathrm{mg} /$ iiter (Fig. 46), and in the other about $40 \mathrm{~m} / \mathrm{d}\left(1000 \mathrm{gpd} / \mathrm{ft}^{2}\right.$ ) for $750 \mathrm{mg}$ PAC/Iiter filtrate (Fig. 47). In the last mentioned run, filtrate was recycled to the feed tank overnight, and final second-stage recovery was only $35 \%$, in comparison to 


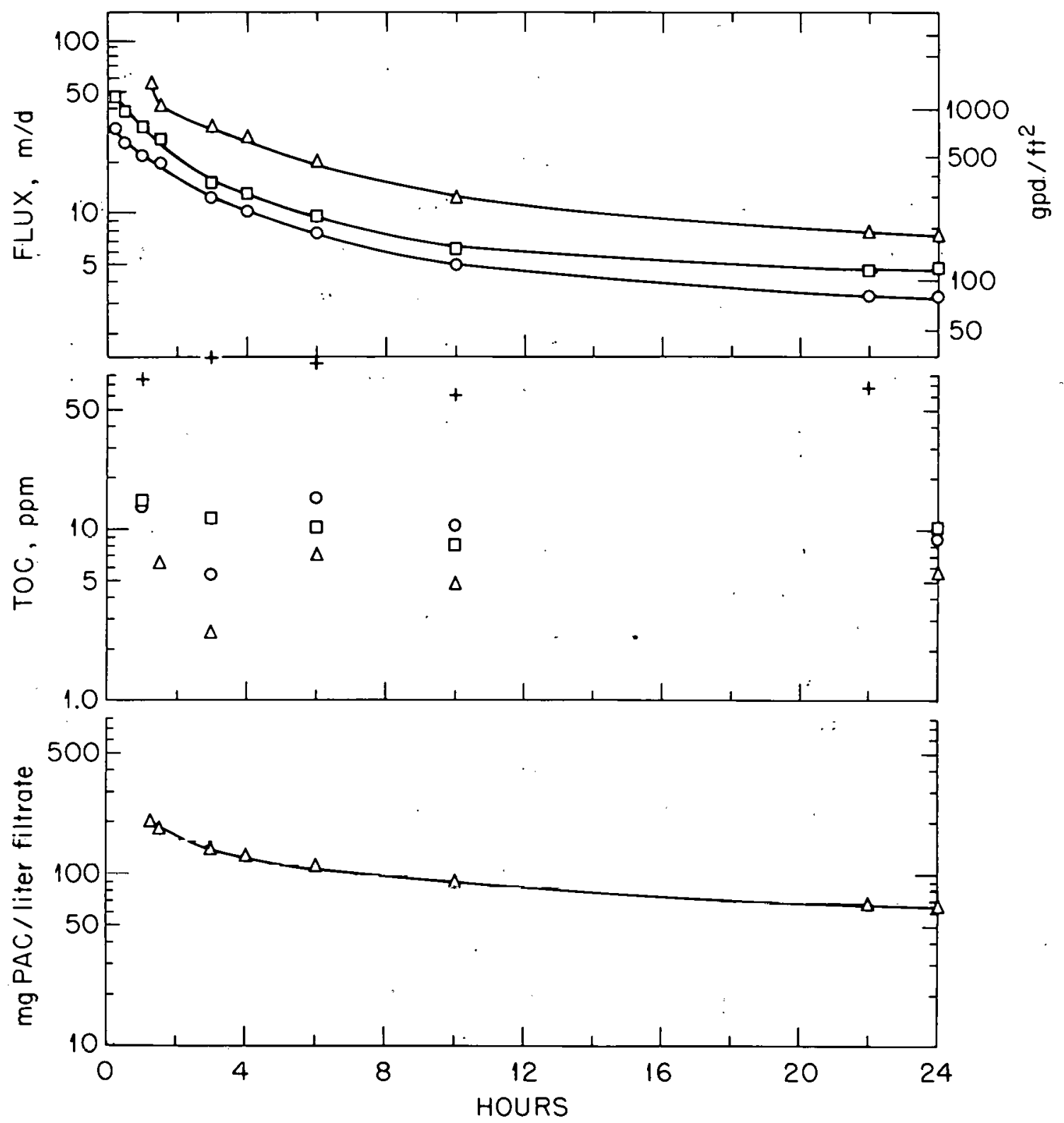

Fig. 45. Two-stage cross-flow filtration of primary effluent.

$$
\text { (15 } \mathrm{ft} / \mathrm{sec}[4.6 \mathrm{~m} / \mathrm{sec}] \text { ) }
$$

First Stage, $\sim 85 \mathrm{ppm} \mathrm{Fe(III)} \quad$ ○ Int

Second Stage

$\Delta$ Ext

Primary Sewage 


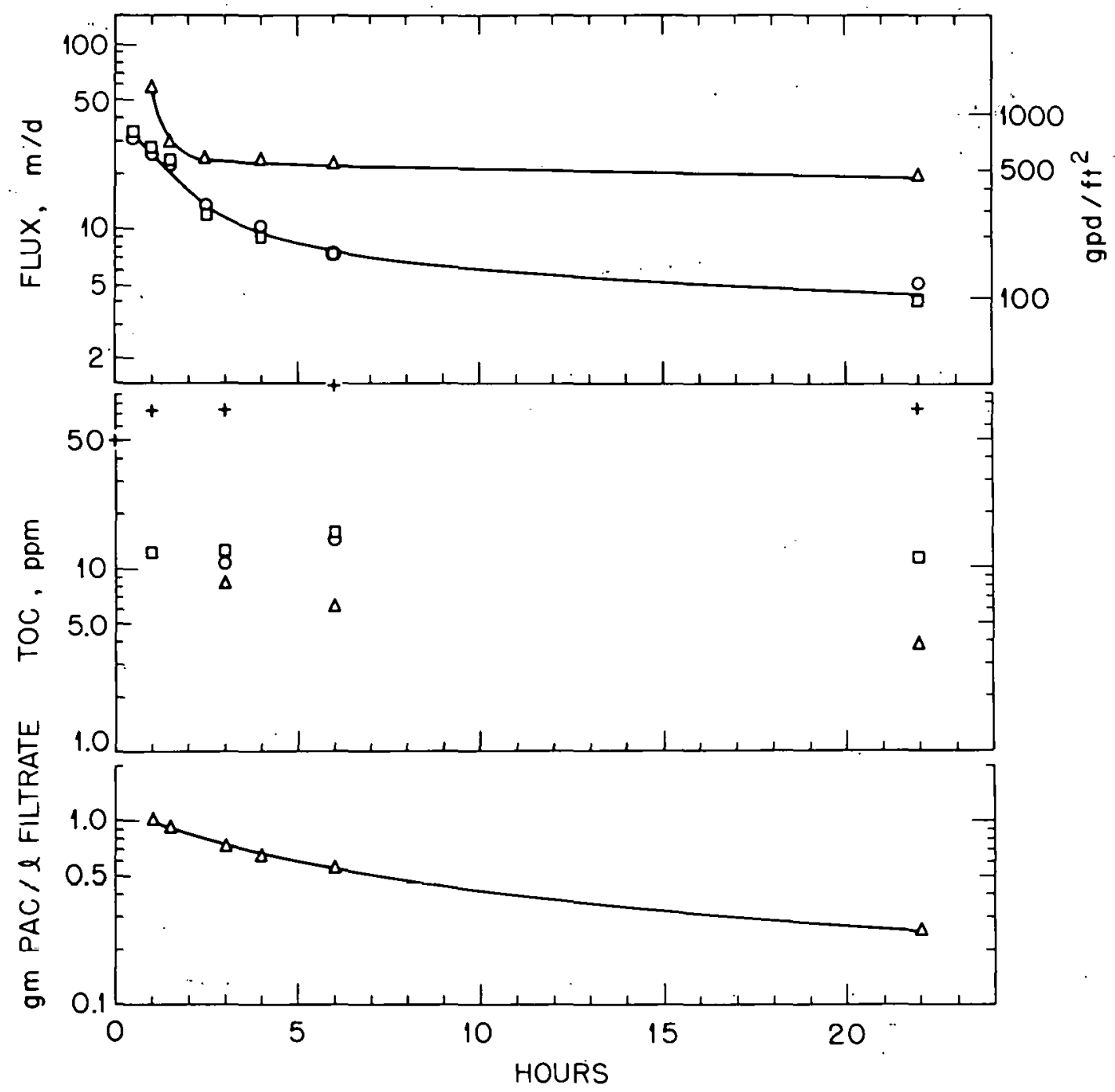

Fig. 46. Two-stage cross-flow filtration of primary effluent. (15 $\mathrm{ft} / \mathrm{sec}[4.6 \mathrm{~m} / \mathrm{sec}]$ )

First Stage, $\sim 75 \mathrm{ppm} F e$ (II) - Int.

Second Stage

- Ext.

Primary Sewage

$\triangle$ Ext. 


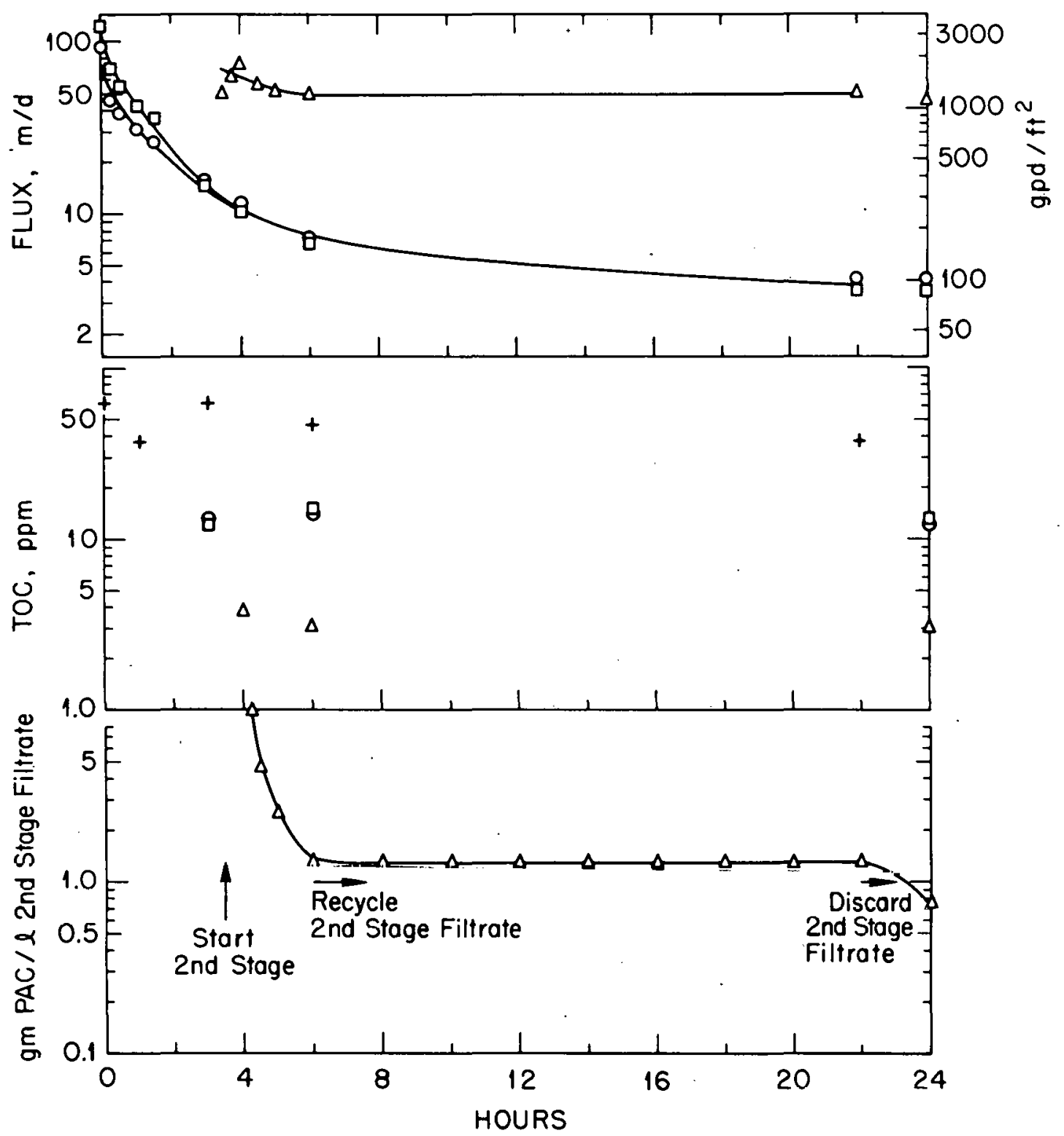

Fig. 47. Two-stage cross-flow filtration of primary effluent. (15 ft/sec $[4.6 \mathrm{~m} / \mathrm{sec}])$

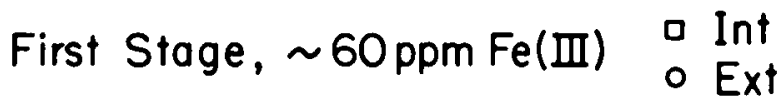

Second Stage

$\Delta$ Ext

Primary Sewage 
65-75\% for the runs of Figs. 45 and 46. Second-stage filtrates were low in phosphate (0.2 ppm or less) and were lower in TOC than first stage filtrate.

If recovery and regeneration of powdered activated carbon from concentrates is feasible, it may be practical to obtain effluents lower in TOC than from treatment with $\mathrm{Fe}$ (III) and $\mathrm{Al}$ (III) alone by contacting with PAC in either single-stage or two-stage cross-flow filtration.

POROUS SUPPORTS, PRECOATS, AND REGENERATION

Most results reported here were obtained with fire-hose jackets. Although these are attractive filter surfaces, they are by no means the only option--porous tubes of various materials could be used. In the earlier stages of the study, a considerable number of tests were made with screens, mostly of stainless steel but also, in a few cases, of nylon. They were mounted in external flow test sections, supported by perforated stainless steel, in a manner similar to that illustrated in Fig. 2. In most cases, they were precoated with fibrous asbestos or cellulosic filteraids, though in some tests with fine screens (e.g., 400 mesh), no filteraid coat was used.

In runs in which test sections of both screen and firehose jackets were present; relative performances were mixed. Somewhat more care in forming precoats appeared necessary with screens than with fire-hose jackets, and, at least with screens coarser than 100 mesh, occurrence of turbid product on occasion indicated instability of the filtercake. Backwashing, surprisingly, was frequently more difficult with screens-when part of the cake had been removed, loss of the pressure hindered removal of the remainder. Attempts were made to assist backwash by electrical pulses generating electrolytic gas. Although cake removal was demonstrated, currents required seemed undesirably high.

With 20 and 40 mesh screens, somewhat higher fluxes were usually obtained than through fire-hose jackets used in the same tests. For three runs in which the circulation velocity was the same or higher for the fire-hose jacket than for 20 and 40 mesh screens used in the same run, fluxes measured at the same times (after 24 to 40 hours of operation) 
averaged $3 \mathrm{~m} / \mathrm{d}\left(70 \mathrm{gpd} / \mathrm{ft}^{2}\right)$ for the fire-hose jacket and $5 \mathrm{~m} / \mathrm{d}$ (120 $\mathrm{gpd} / \mathrm{ft} \mathrm{t}^{2}$ ) for 20 and 40 mesh screens. On the other hand, for ten short runs (of a few hours) in which a 120-mesh stainless steel screen was operated at either the same $4.6 \mathrm{~m} / \mathrm{sec}(15 \mathrm{ft} / \mathrm{sec})$ or higher circulation velocity than a fire-hose jacket (both external flow of feed), measurements near the end of the runs averaged $\sim 33 \mathrm{~m} / \mathrm{d}\left(\sim 800 \mathrm{gpd} / \mathrm{ft}^{2}\right)$ for the fire-hose jacket and $\sim 16 \mathrm{~m} / \mathrm{d}\left(\sim 400 \mathrm{gpd} / \mathrm{ft}^{2}\right)$ for the screen.

Backwashing is the most obvious regeneration method, when internally supported filter surfaces are used and pressurized solution is circulated on the outside. Fig. 48 illustrates in successive short-term runs with primary effluents ( $0 \%$ water recovery) the restoration of $f l u x$, and also compares the effects of precoats of two different filteraids with no filteraid. The precoating in this case was carried out at relatively high circulation velocity, which results in a thin layer adherent when circulation is stopped and pressure removed. In an alternative procedure commonly used in this study, a much thicker precoat is obtained at low circulation velocity, but the sewage effluent to be treated must be introduced without shutting down, or the coat will tend to flake off; since we wished to compare coats in this case, and a shutdown was required for one, the high-circulation-velocity, adherent thin coat was used. It has been customary to include a little powdered activated carbon (say, $10 \mathrm{mg} / \mathrm{l}$ ) in the water slurry of filteraid used in precoating, to adsorb substances left in the system which might be deleterious to flux.

For regeneration in the runs of Fig. 48, the inside of the test section tube was first filled with water and $550,000 \mathrm{~N} / \mathrm{m}^{2}$ (80 psi) compressed air turned on for five seconds. This was repeated five times. Tap water was then pumped past the test section at $4.6 \mathrm{~m} / \mathrm{sec}(15 \mathrm{ft} / \mathrm{sec}$ ) to $6 \mathrm{~m} / \mathrm{sec}(20 \mathrm{ft} / \mathrm{sec})$ for ten minutes with the product valve closed. The procedure is fairly typical of that used in the work described throughout this report, though variations such as circulation of sulfuric acid solutions were sometimes tried. Filter surfaces can also of course be scrubbed, if desired.

The results in Fig. 48 indicated success in restoring flux. The lower rate of flux decline on the second and third days may result from dilute feed, rainfall being heavy during this series. 


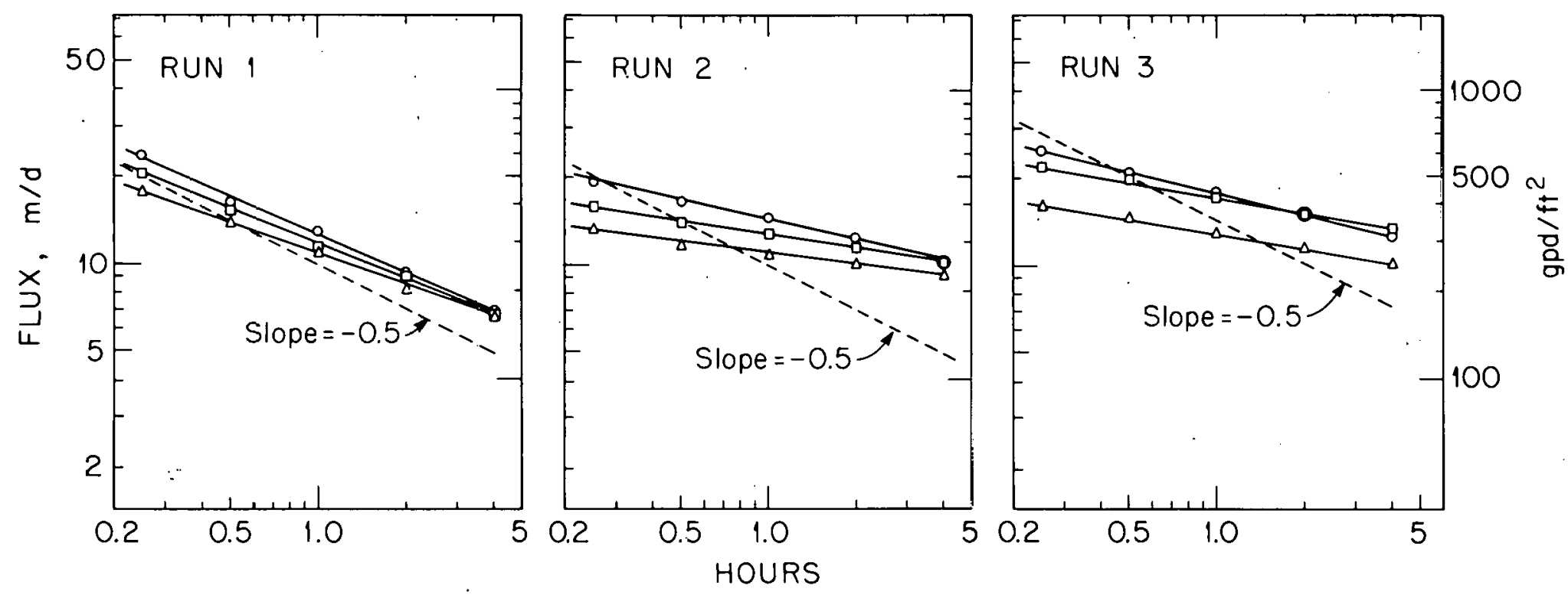

Fig. 48. Regeneration by backwashing; comparison of precoats.

(Fire-rose jackets; external flow; 40 psi [2.8 bar];

$15 \mathrm{ft} / \mathrm{sec}[4.6 \mathrm{~m} / \mathrm{sec}] ; 50 \mathrm{ppm} \mathrm{Fe} ; \mathrm{pH} 7.5-8)$

\section{Precoat}

- Medium Fiber Asbestos

- Cellulosic (Solkafloc BW 200)

$\triangle$ No Precoat 
In conformity with other experience during this study, asbestos and cellulosic filteraid seemed advantageous in comparison with no precoat in maintaining flux in successive runs. Fluxes with asbestos were a little higher here than with cellulose, but the advantage seemed to diminish with successive tests.

Figure 49 illustrates regeneration over a more extended series (over seventy runs) with a single fire-hose-jacket test section. The fluxes compared are those measured in each run after two hours operation. It appears, when account is taken of the generally higher fluxes obtained with PAC than with hydrolyzable ion additives, that regeneration is reasonably successful by the procedures used. The apparent decline after sixty runs likely results from the experiments being carried out, rather than hose deterioration, since fluxes through fresh hoses run simultaneously were also lower.

Flow of solutions to be filtered inside tubes is attractive in comparison to external pressurization because of simplicity of equipment design and the considerable savings realized from omission of pressure support-fire-hose jackets have been operated at up to $3,450,000 \mathrm{~N} / \mathrm{m}^{2}$ (500 psi) with internal circulation without occurrence of sprays from stretching of fabric. However, regeneration procedures involving backwashing are not feasible without complicating design. Other methods to clean surfaces are conceivable, such as chemical washes. Figure 50 indicates that this may well be possible. Two lengths of hose jackets, $A$ and $B$, were used in alternating runs with inside flow in the test module of Fig. 5. Between runs, they were soaked in $1 \underline{\mathrm{MCl}} \mathrm{HC}$ in the exception noted in the figure the hose was allowed to dry, and air was blown through before the next run. The results show that the fluxes for the internal flow test section were comparable to an externally pressurized test section (regenerated by usual backwash procedures) used simultaneously.

Although we have not yet developed a routine less cumbersome than removing and soaking hoses, nor looked for optimum conditions for satisfactory regeneration, we believe it likely that satisfactory procedures can be worked out. Drying might be particularly attractive, if preliminary favorable results were confirmed in repetitive operations. 


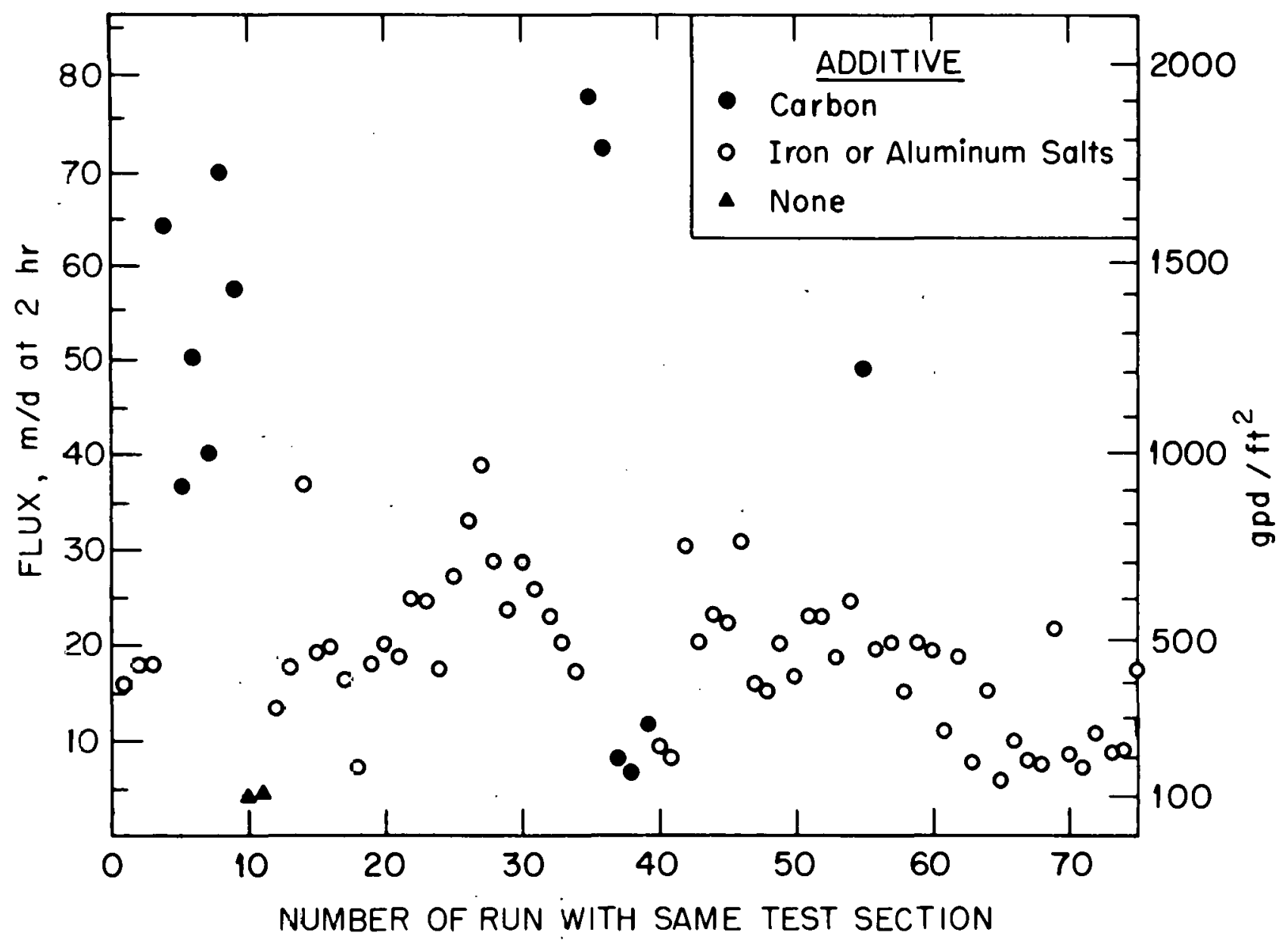

Fig. 49. Regeneration by backwashing; comparison of fluxes in successive runs.

(Fire-hose jacket; ext. pressure) 


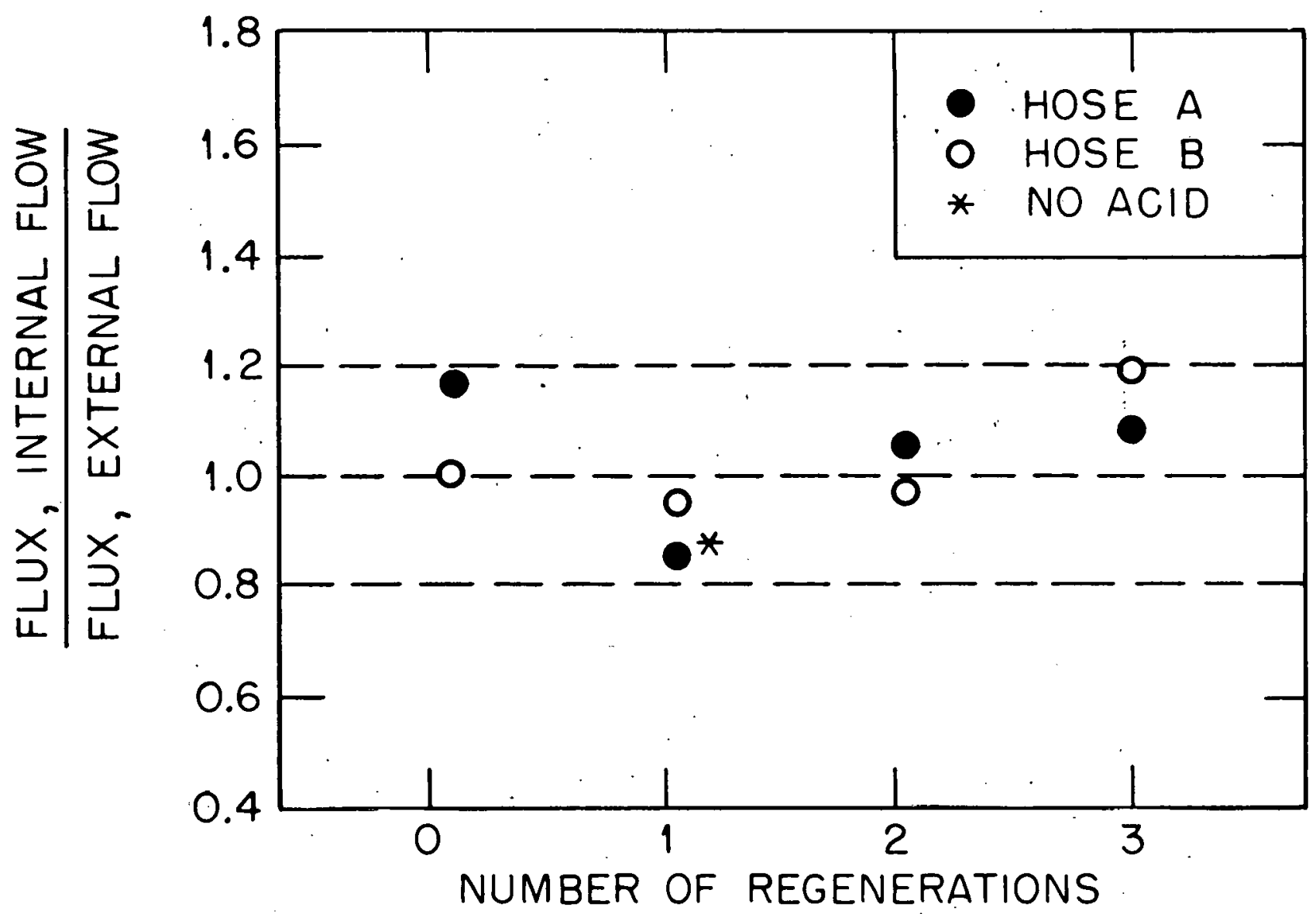

Fig. 50. Regeneration of fire-hose jackets.

(Outside flow - backwashing; inside flow - acid soak) 


\section{DISCUSSION}

The results reported here indicate that cross-flow filtration of the effluent from primary treatment of municipal sewage, following addition of salts containing (or producing on oxidation) $\mathrm{Fe}$ (III) or $\mathrm{Al}$ (III), produces a filtrate superior by most of the usual criteria to the typical product of biological secondary treatment--turbidities usually below 1 JTU; TOC, 10 to $15 \mathrm{mg} / \ell$; total phosphorus, below $1 \mathrm{mg} / \ell$, expressed as phosphate (if expressed as $P$, the value would be about one third as large); and low microorganism content. Filtrate after powdered activated carbon treatment is comparable, except that it is usually lower in TOC, around $5 \mathrm{mg} / \ell$, and phosphate is not efficiently removed, the filtrate containing about as much phosphate as the feed. Lower TOC contents can be obtained with Fe(III) or $\Lambda 1$ (III) either by additional PAC treatment or by using effluent from biological secondary processing as feed. Filtrates appear superior to products of physical-chemical treatments discussed in the introduction, when solids-liquid separations were effected by settling, except perhaps when tube settlers were used. 11

Costs are of course a major factor in evaluation of the possible usefulness. These in turn will depend heavily on the flux attainable. Before discussing these aspects, certaln reservations about conclusions which can be drawn from the limited scope of work so far should be noted.

An important one is the question of disposition of the concentrate, perhaps $5 \%$ of the total volume processed, but probably less. Hopefully, it can be recirculated to the inflow of the primary settler, and the solids removed in that stage, to be eventually disposed of with the rest of the sludge by anaerobic digestion or otherwise. Other work ${ }^{3}$ has indicated that presence of these additives does not have a deleterious pffect on digcstoi uperation, and in fact, it has been suggested that 
Fe(III) might improve operation, by reacting with sulfides and thus lowering $\mathrm{H}_{2} \mathrm{~S}$ in the $\mathrm{CH}_{4}$ produced. Cross-flow filtration concentrates appear to settle well, but a test on a scale of essentially the full output of a primary unit will be necessary to establish that the primary effluent is not affected to an undesirable extent by the addition of the concentrate. Should this procedure prove unfavorable, other techniques, including standard filtration approaches, likely will be feasible for the relatively small volumes involved.

The tests reported here were for a waste waters of a suburban type community, with relatively small inputs from industries. Conclusions concerning performance with effluents generated by large urban complexes require further work.

There are some differences between our experimental conditions and those to which feeds in a practical system would be exposed. Perhaps the most important is frequency of passing through the pumps, which subject the liquids to high shear. In a sewage plant, the filtration units would presumably be long compared to those in these tests, and the circulating solution would pass through pumps fewer times for a given water recovery. Consequently, the particle size at the filter surface may be larger in a practical slludion: It might be hnped that fluxes would be better than in these experiments, but this cannot be confidently predicted.

One further comment, on criteria, applies to sewage treatment methods in general, not just cross-flow filtration. Evaluation in terms of such inclusive measurements as TOC or BOD seems to us inadequate. A more detailed inventory of the components of the treated streams and their effects appears needed. Since obtaining such information and determining significance of various classes of 1mpurities discharged into different receiving waters is a formidable undertaking, use of the present nonspecific criteria is understandable. However, it is likely that the TOC of water treated by different processes is made up of components having quite different environmental effects, and final judgment on new processes should be delayed until sounder bases of evaluation exist. The lower bacterial content of cross-flow filtrate might, for example, make more acceptable discharge without disinfection should chlorination be restricted becaus of concern about organochlorine compounds. 
costs

Discussion of costs can conveniently be divided into costs of crossflow filtration, costs of chemicals, and costs of operations included in feed pretreatment.

\section{Cross-Flow Filtration}

Costs of cross-flow filtration were treated earlier in this program by Wadia, Kraus, Shor and Dresner in Reference 29, and we shall only outline their approach and conclusions. Their analysis was of an operation applicable to sewage treatment, but not restricted to it. A number of parameters (Table 6) was investigated--plant size, average flux, and circulation velocity, as well as plants with minimum instrumentation vs automated plants. The central set of conditions, from which the effect of variations was assessed, was a $3800 \mathrm{~m}^{3} / \mathrm{d}\left(10^{6} \mathrm{gpd}\right)$ plant, producing filtrate at a rate of $6.1 \mathrm{~m} /$ day $\left(150 \mathrm{gpd} / \mathrm{ft}^{2}\right)$ when in operation at $4.6 \mathrm{~m} / \mathrm{sec}(15 \mathrm{ft} / \mathrm{sec})$ circulation velocity. Within the range of conditions covered, costs of filtration for a plant of a given flux can be estimated, and optimum circulation velocities can be selected, if flux dependence on velocity has been established for the feed in question.

Effect of pressure and water recovery on flux were included in the average flux; as the results presented in this report indicate, these do not to a first approximation appear to affect flux greatly. A layout for a typical plant is illustrated in Fig. 51, which helps to define some of the terms in Table 6. "Tiers" are regions from which one or more pumping circuits feed and into which reject is discharged. As filtrate is removed, and fresh feed brought into Tier 1, flow over a weir into Tier 2 maintains recovery at a design steady-state figure. For different sized plants, recovery varies from 50 to $66 \%$ in Tier 1 , and is brought to $\mathrm{ca}$. $95 \%$ in second, and, in some cases, third tiers. Tiers thus allow tapered plant design. The several recirculating "pumping circuits" (p. c.) operating on each tier each incorporates one filtration module: The capacity of the individual pumping circuits fixes the number necessary and can be selected to match available equipment and to increase reliability by use of smaller units, if desired. "Recyr.le ratio" is the ratio of volume taken inlu a module to filtrate volume per unit time. 
Table 6. PLANT CHARACTERISTICS ${ }^{a}$

\begin{tabular}{|c|c|c|c|c|c|c|c|c|c|c|c|c|}
\hline $\begin{array}{r}\text { Plant } \\
\text { Nomina1 } \\
\text { (gpd) } \\
\end{array}$ & $\begin{array}{r}\text { capacity } \\
\text { Actual } \\
(\text { gpd }) \\
\end{array}$ & $\begin{array}{l}\text { Design } P \\
\text { Velocity } \\
\text { (ft/sec) }\end{array}$ & $\begin{array}{c}\text { parameters } \\
\text { Flux } \\
\left(\mathrm{gpd} / \mathrm{ft}^{2}\right)\end{array}$ & $\begin{array}{r}\text { Numbe } \\
\text { p } \\
\text { Tier } \\
\text { I }\end{array}$ & $\begin{array}{c}\text { er of } \\
\in \text { r ti } \\
\text { Tier } \\
\text { LI }\end{array}$ & $\begin{array}{l}\text { mods. } \\
\text { er } \\
\text { Tier } \\
\text { III } \\
\end{array}$ & $\begin{array}{r}\text { C } \\
\text { Pres } \\
\text { (psi) }\end{array}$ & $\begin{array}{l}\text { irculation } \\
\text { s. head } \\
\left(10^{3} \mathrm{~N} / \mathrm{m}^{2}\right)\end{array}$ & $\begin{array}{l}\text { pump } \\
\text { Circ. } \\
\text { rate } \\
\text { (gpm) }\end{array}$ & $\begin{array}{l}\text { ratings } \\
\text { Motor } \mathrm{hp}^{\mathrm{b}} \\
\text { consumption }\end{array}$ & $\begin{array}{c}\text { No. of } \\
\text { pumps } \\
\text { circuits }\end{array}$ & $\begin{array}{c}\text { Average } \\
\text { recycle } \\
\text { ratio } \\
\end{array}$ \\
\hline $10^{5}$ & $1.12 \times 10^{5}$ & 15 & 150 & 1 & 1 & - & 50 & 345 & 630 & 25 & 2 & 16.2 \\
\hline $10^{6}(\mathrm{~A})$ & $1.12 \times 10^{6}$ & 15 & . 75 & 2 & 1 & - & 105 & 724 & 3,500 & 250 & 3 & 13.5 \\
\hline $10^{6}(\mathrm{~B})$ & $1.12 \times 10^{6}$ & 15 & 150 & 4 & 2 & 1 & 60 & 414 & 1,370 & 60 & 7 & 12.3 \\
\hline $10^{6}(\mathrm{C})$ & $1.12 \times 10^{6}$ & 15 & 150 & 2 & 1 & - & 70 & 483 & 2,800 & 135 & 3 & 10.8 \\
\hline $10^{6}(\mathrm{D})$ & $1.12 \times 10^{6}$ & 10 & 150 & 4 & 2 & 1 & 30. & 207 & 980 & 25 & 7 & 8.6 \\
\hline $10^{6}(E)$ & $1.11 \times 10^{6}$ & 10 & 300 & 2 & 1 & - & 30 & 207 & 1,180 & 25 & 3 & 4.6 \\
\hline $10^{6}(\mathrm{~F})$ & $1.13 \times 10^{6}$ & 15 & 600 & 2. & 1 & - & 50 & 345 & 1,100 & 45 & 3 & 4.2 \\
\hline $10^{7}$ & $1.11 \times 10^{7}$ & 15 & 150 & 6 & 4 & $\therefore$ & 110 & 759 & 5,000 & 365 & 10 & 6.4 \\
\hline
\end{tabular}




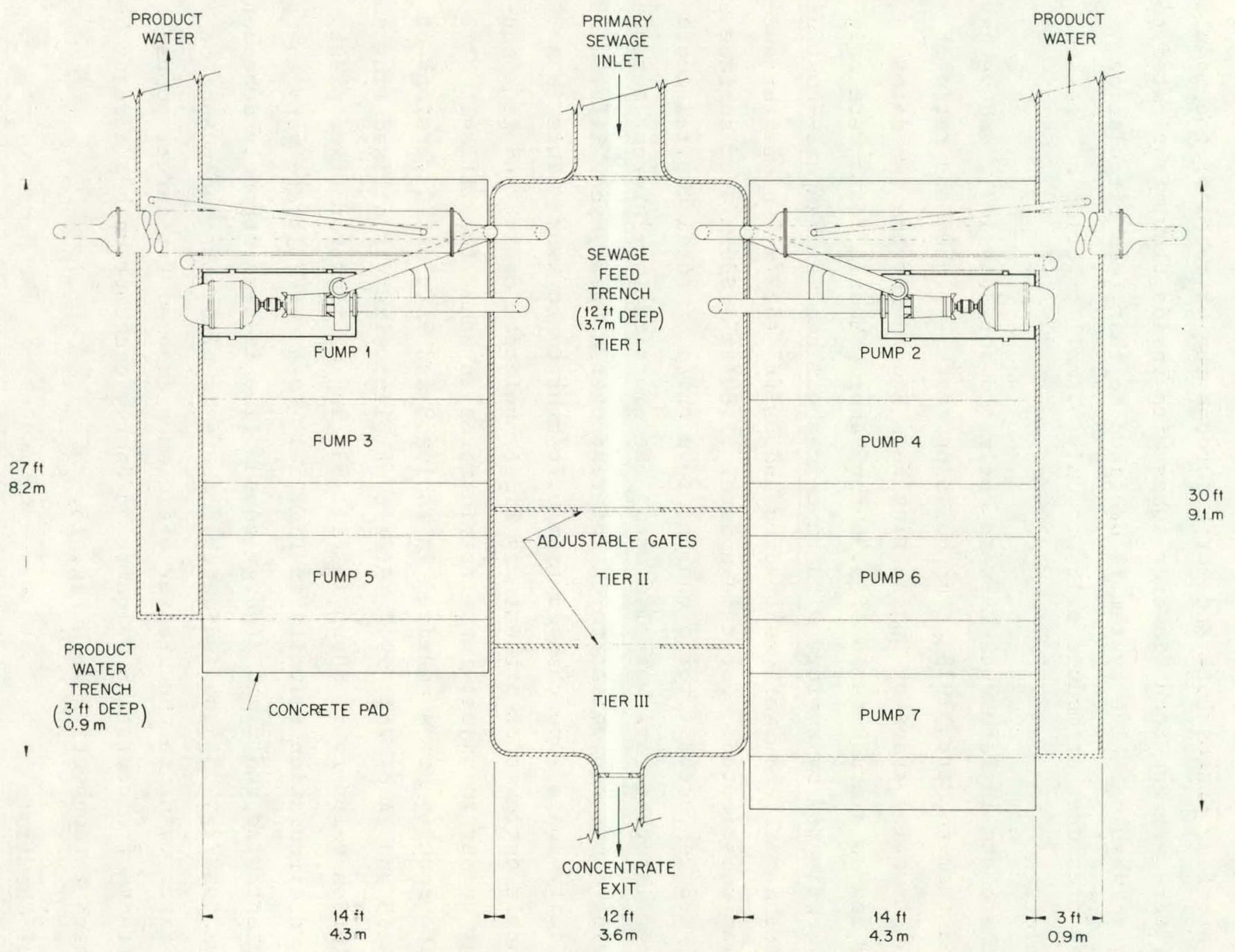

Fig. 51. Plan for a $3788 \mathrm{~m}^{3} /$ day $\left(10^{6} \mathrm{gpd}\right)$ cross-flow filtration plant. 
Characteristics assumed for the modules are listed in Table 7, see also Fig. 52. Circulating solution passes in parallel through groups of tubes (for example, groups of 17 in modules of the $10^{5}$ gpd plant, so that there are four passes back and forth through the 68 tubes of the module). The filters are one-inch diameter tubes with inside flow, fabricated to allow backwashing. The system is designed so that feed circulation reduces pressures at module exits to only a small fraction of pressure at the inlet.

The costs in Reference 29 were estimated for July 1971, and we have updated them to March 1975. For building costs, we used the ratio of the construction index of Engineering News Record for the two dates, 1.335, and an average ratio of 1.30 for labor. Module costs were originally estimated by analogy with tube-in-shell heat exchangers--cost of heat exchanger tubes were subtracted and $\$ 2 / \mathrm{ft}^{2}\left(\$ 22 / \mathrm{m}^{2}\right)$ of filter surface was substituted. For this update, $\$ 2.80 / \mathrm{ft}^{2}\left(\$ 30 / \mathrm{m}^{2}\right)$ of surface was used. Modules account for a quarter to a third of total capital cost. A higher interest rate was also used, the amortization-interest assumed now being $8.6 \%$, equivalent to $6 \%$ interest over a twenty-year life. Electricity costs were changed from $0.7 \mathrm{c} / \mathrm{kwhr}$ to $1 \mathrm{c} / \mathrm{kwhr}$. This is a reasonable estimate of present Oak Ridge municipal costs, and is a convenient number to adjust for electric rates in other localities.

The results are summarized in Tables 8 and 9 (updated versions of Tables 13 and 14 of Ref. 29). Effect of plant size for a fixed flux and circulation velocity is shown in Fig. 53 and of flux for fixed plant size and circulation velocity in Fig. 54. Costs of filtrate vary sharply with plant size and flux. Energy consumption is also strongly dependent on flux (as Fig. 15 also indicates); there is also some dependence on plant size, owing to the greater efficiency assumed for larger pumps. The effect of circulation velocity on energy consumption has already been discussed in connection with Fig. 15.

\section{Cost of Chemicals}

Chemical requirements will vary with the composition of the sewage, and the costs presented here, based mainly on our experience with Oak Ridge municipal primary effluent, can be viewed as only a rough guide. 
Table 7. MODULE CHARACTERISTICS ${ }^{a}$

\begin{tabular}{|c|c|c|c|c|c|c|c|c|}
\hline $\begin{array}{l}\text { Nomina1 } \\
\text { capacity } \\
\text { (gpd) }\end{array}$ & $\begin{array}{c}\text { Design } \\
\text { Velccity } \\
\text { (ft/sec) } \\
\end{array}$ & $\begin{array}{c}\text { parameters } \\
\text { Flux } \\
\left(\mathrm{gpd} / \mathrm{ft}^{2}\right)\end{array}$ & $\begin{array}{c}\text { Total } \\
\text { module area } \\
\left(f \mathrm{t}^{2}\right)\end{array}$ & $\begin{array}{l}\text { Production } \\
\text { per module } \\
\text { (gpd) }\end{array}$ & $\begin{array}{l}\text { Tube } \\
\text { length } \\
\text { (ft) }\end{array}$ & $\begin{array}{l}\text { Approx. } \\
\text { shell dia. } \\
\text { (in) }\end{array}$ & $\begin{array}{c}\text { Number of } \\
\text { tubes per } \\
\text { pass }\end{array}$ & $\begin{array}{l}\text { Number of } \\
\text { tube passes }\end{array}$ \\
\hline $10^{5}$ & 15 & 150 & 370 & $5.6 \times 10^{4}$ & 21.0 & 12 & 17 & 4 \\
\hline $10^{6}(\mathrm{~A})$ & 15 & 75 & 4,980 & $3.7 \times 10^{5}$ & 40.0 & 32 & 95 & 5 \\
\hline $10^{6}(\mathrm{~B})$ & 15 & 150 & 1,070 & $1.6 \times 10^{5}$ & 22.0 & 20 & 37 & 5 \\
\hline $10^{6}(\mathrm{C})$ & 15 & 150 & 2,490 & $3.7 \times 10^{5}$ & 25.0 & 27 & 76 & 5 \\
\hline $10^{6}(\mathrm{D})$ & 10 & 150 & 1,070 & $1.6 \times 10^{5}$ & 22.0 & 20 & 37 & 5 \\
\hline $10^{6}(\mathrm{E})$ & 10 & 300 & 1,230 & $3.7 \times 10^{5}$ & 25.0 & 20 & 47 & 4 \\
\hline $10^{6}(\mathrm{~F})$ & 15 & 600 & 630 & $3.8 \times 10^{5}$ & 20.0 & 16 & 30 & 4 \\
\hline $10^{7}$ & 15 & 150 & 7,390 & $1.11 \times 10^{6}$ & 41.5 & 36 & 136 & 5 \\
\hline
\end{tabular}


Table 8. CROSS-FLOW FILTRATION - COST SUMMARY

(Non-Automated Flant; ${ }^{*} 95 \%$ Water Recovery)

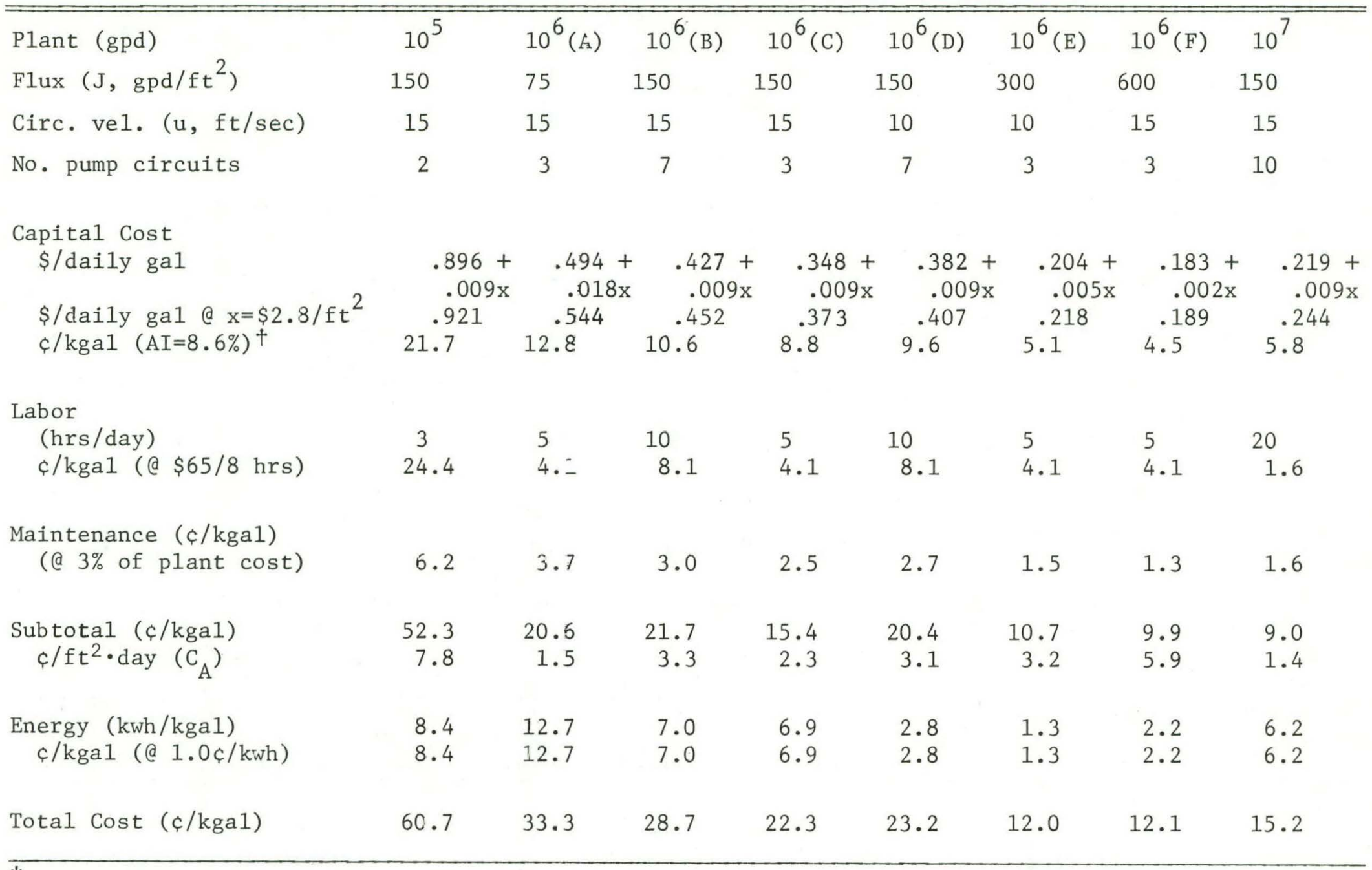

* Cases A, B, C, D, E, F - see Table 7 .

${ }^{\dagger}$ AI signifies amortization-interest. $8.5 \%$ corresponds to 20 years amortization at $6 \%$ interest. 
Table 9. CROSS-FLOW FILTRATION - COST SUMMARY

(Automated Plant;* 95\% Water Recovery)

\begin{tabular}{|c|c|c|c|c|c|c|c|c|}
\hline Plant (gpd) & $10^{5}$ & $10^{6}(\mathrm{~A})$ & $10^{6}(\mathrm{~B})$ & $10^{6}(\mathrm{C})$ & $10^{6}(\mathrm{D})$ & $10^{6}(\mathrm{E})$ & $10^{6}(\mathrm{~F})$ & $10^{7}$ \\
\hline Flux $\left(J, g p d / f t^{2}\right)$ & $15)$ & 75 & 150 & 150 & 150 & 300 & 600 & 150 \\
\hline Circ. ve1. ( $\mathrm{u}, \mathrm{ft} / \mathrm{sec})$ & 15 & 15 & 15 & 15 & 10 & 10 & 15 & 15 \\
\hline No. pump circuits & 2 & 3 & 7 & 3 & 7 & 3 & 3 & 10 \\
\hline $\begin{array}{l}\text { Capital Cost } \\
\$ / \text { daily gal } \\
\$ / \text { daily gal @ } \mathrm{x}=\$ 2.8 / \mathrm{ft}^{2} \\
\text { c/kgal }(\mathrm{AI}=8.6 \%)\end{array}$ & $\begin{array}{l}1.215+ \\
\quad .009 \mathrm{x} \\
1.240 \\
29.2\end{array}$ & $\begin{aligned} .542+ \\
.018 x \\
.592 \\
13.9\end{aligned}$ & $\begin{array}{c}.539+ \\
.009 x \\
.565 \\
13.3\end{array}$ & $\begin{array}{l}.396+ \\
.009 x \\
.421 \\
9.9\end{array}$ & $\begin{array}{c}.493+ \\
.009 x \\
.518 \\
12.2\end{array}$ & $\begin{array}{l}.254+ \\
\times .005 x \\
.268 \\
6.3\end{array}$ & 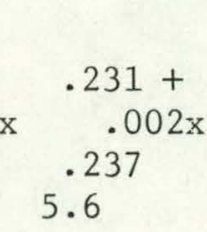 & 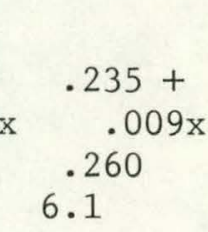 \\
\hline $\begin{array}{l}\text { Labor } \\
\qquad(\text { hrs/day) } \\
\text { c/kgal (@ } \$ 55 / 8 \text { hrs) }\end{array}$ & $\begin{array}{l}1.0 \\
8.1\end{array}$ & $\begin{array}{l}1.5 \\
1.2\end{array}$ & $\begin{array}{l}2.5 \\
2.0\end{array}$ & $\begin{array}{l}1.5 \\
1.2\end{array}$ & $\begin{array}{l}2.5 \\
2.0\end{array}$ & $\begin{array}{l}1.5 \\
1.2\end{array}$ & $\begin{array}{l}1.5 \\
1.2\end{array}$ & $\begin{array}{l}4.0 \\
0.3\end{array}$ \\
\hline $\begin{array}{l}\text { Maintenance (c/kga } 1) \\
\quad \text { (@ } 3 \% \text { of plant cost) }\end{array}$ & 8.2 & 4.0 & 3.8 & 2.8 & 3.5 & 1.8 & 1.6 & 1.7 \\
\hline $\begin{array}{l}\text { Subtotal (c/kgal) } \\
c / f t^{2} \cdot \text { day }\left(C_{A}\right)\end{array}$ & $\begin{array}{r}45.5 \\
6.8\end{array}$ & $\begin{array}{r}19.1 \\
1.4\end{array}$ & $\begin{array}{r}19.1 \\
2.9\end{array}$ & $\begin{array}{r}13.9 \\
2.1\end{array}$ & $\begin{array}{r}17.7 \\
2.7\end{array}$ & $\begin{array}{l}9.3 \\
2.8\end{array}$ & $\begin{array}{l}8.4 \\
5.0\end{array}$ & $\begin{array}{l}8.1 \\
1.2\end{array}$ \\
\hline $\begin{array}{l}\text { Energy }(\mathrm{kwh} / \mathrm{kgal}) \\
\text { c/kgal }(@ 1.0 \mathrm{c} / \mathrm{kwh})\end{array}$ & $\begin{array}{l}8.4 \\
8.4\end{array}$ & $\begin{array}{l}12.7 \\
12.7\end{array}$ & $\begin{array}{l}7.0 \\
7.0\end{array}$ & $\begin{array}{l}6.9 \\
6.9\end{array}$ & $\begin{array}{l}2.8 \\
2.8\end{array}$ & $\begin{array}{l}1.3 \\
1.3\end{array}$ & $\begin{array}{l}2.2 \\
2.2\end{array}$ & $\begin{array}{l}6.2 \\
6.2\end{array}$ \\
\hline Tctal Cost (c/kgal) & 53.9 & 31.8 & 26.1 & 20.8 & 20.5 & 10.6 & 10.6 & 14.3 \\
\hline
\end{tabular}

Cases A, B, C, D, E, F - see Tajle 7.

${ }^{\dagger}$ AI signifies amortization-interest. $8.6 \%$ corresponds to 20 years amortization at $6 \%$. 


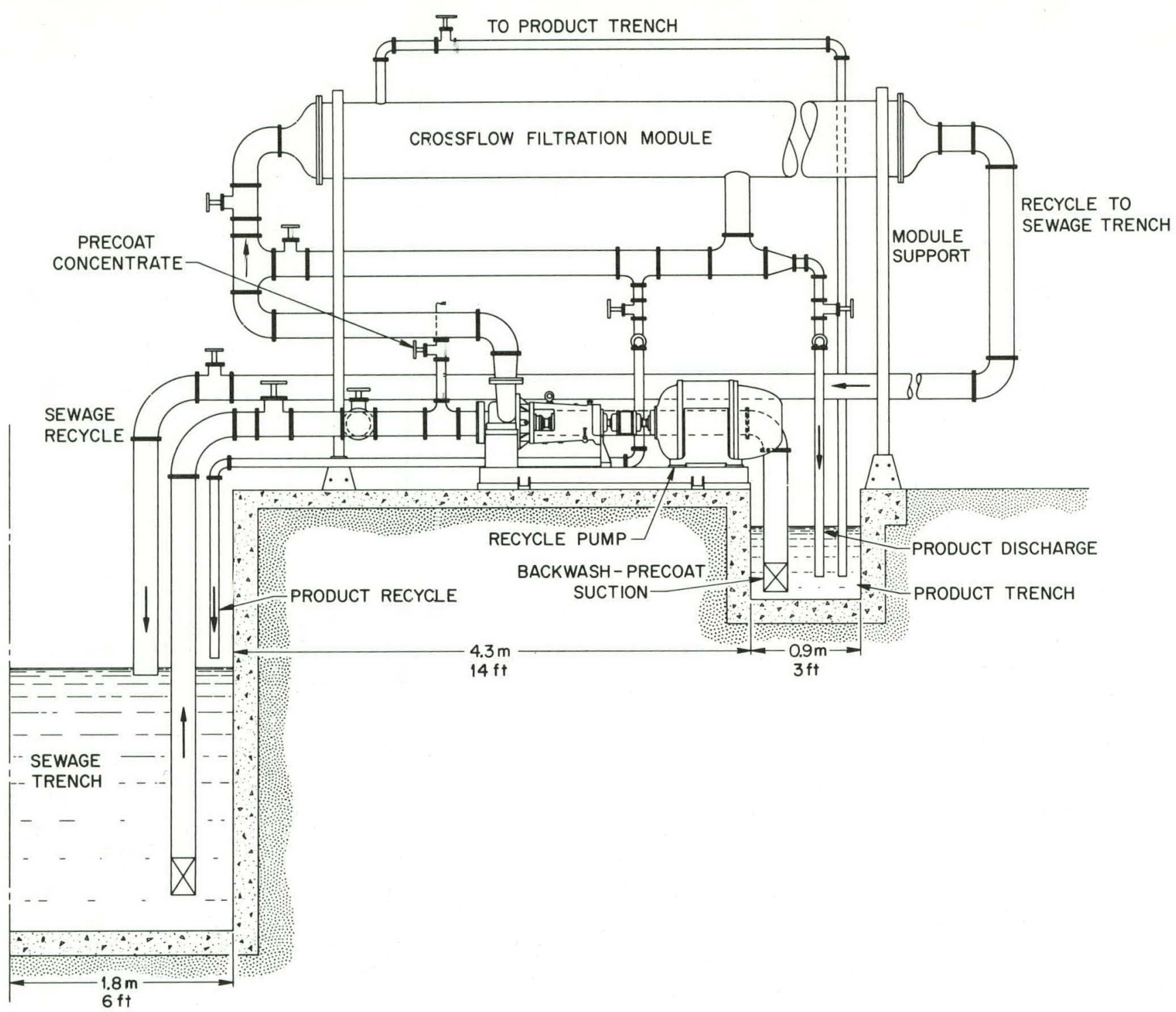

Fig. 52. Elevation of a cross-flow filtration plant module. 


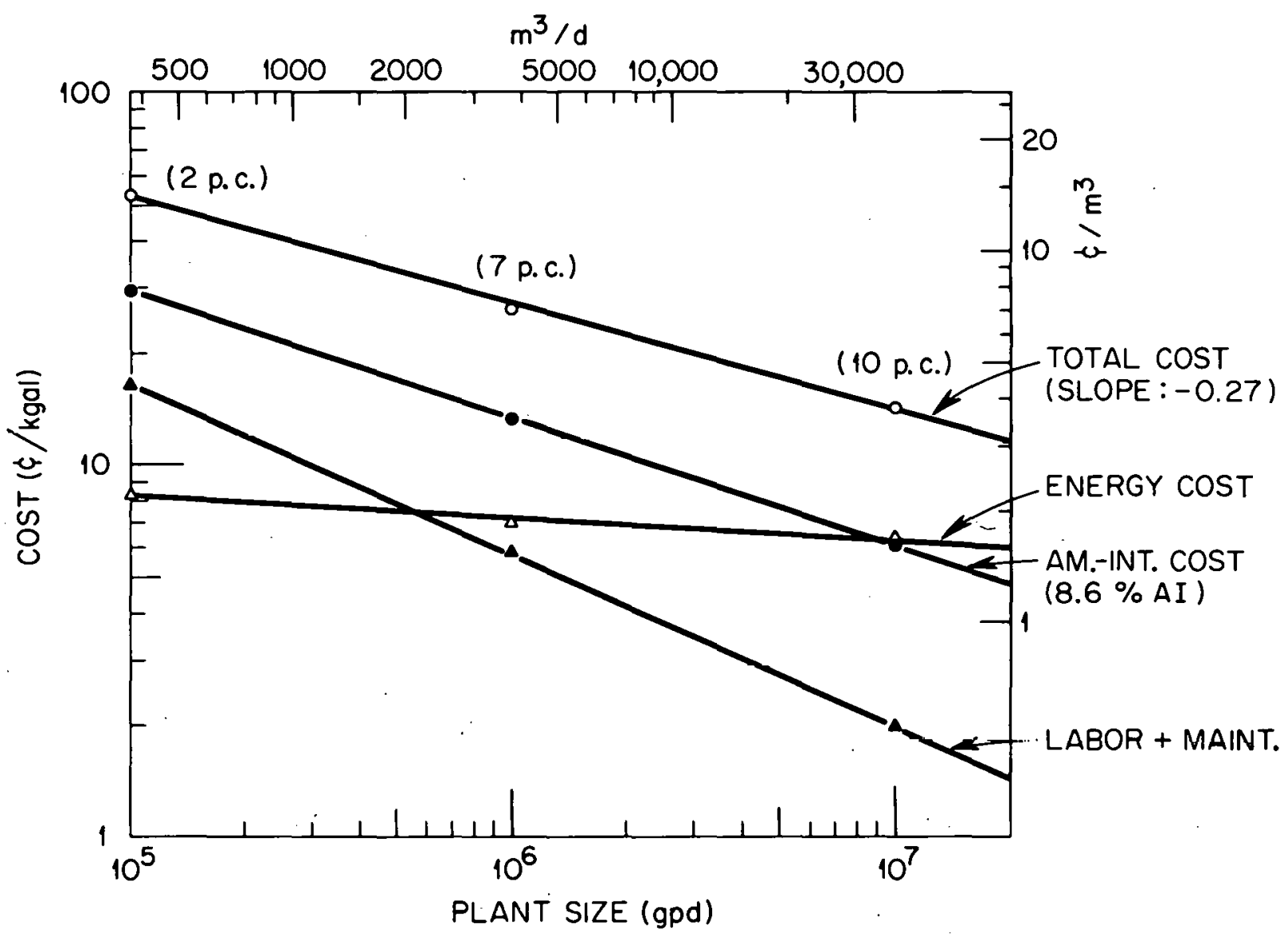

Fig. 53. Cross-flow filtration-dependence of operating cost on plant size.

(15 ft/sec $[4.6 \mathrm{~m} / \mathrm{sec}] ; 1.50 \mathrm{gpd} / \mathrm{ft}^{2}[6.1 \mathrm{~m} / \mathrm{d}]$; automated plant; (p.c. $\equiv$ pumping circuits) 


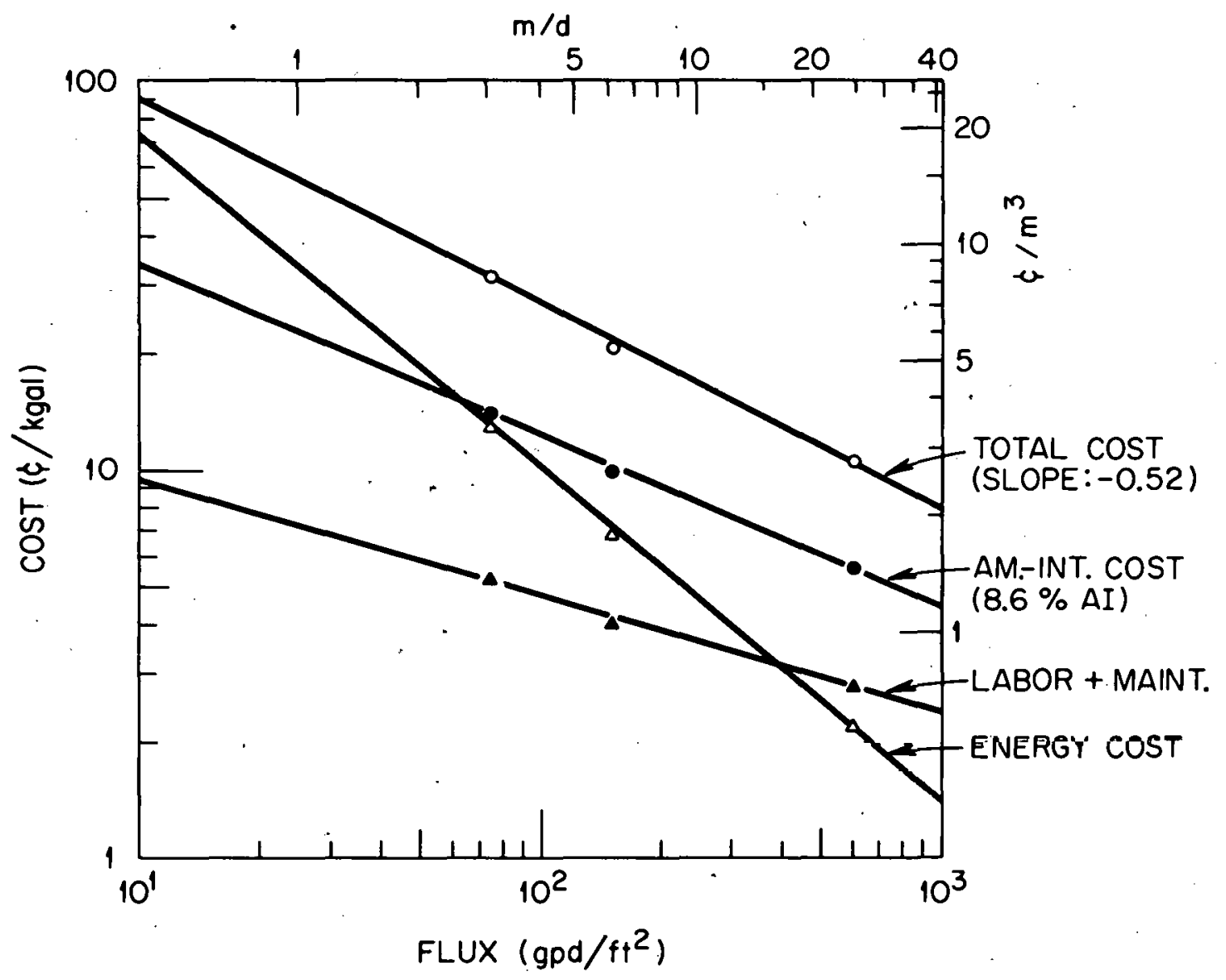

Fig. 54. Cross-flow filtration-dependence of operating cost on flux. $\left(10^{6} \mathrm{gpd}\left[3788 \mathrm{~m}^{3} / \mathrm{d}\right] ; 3\right.$ pumping circuits; $15 \mathrm{ft} / \mathrm{sec}[4.6 \mathrm{~m} / \mathrm{d}]$; automated plant) 
Day-to-day variations in base and acid requirements emphasize the uncertainty. We shall adopt for illustration a sequence of addition of $50 \mathrm{mg} / \mathrm{l} \mathrm{Fe}(\mathrm{II})$ as ferrous sulfate (oxidized to $\mathrm{Fe}$ (III) by air) and enough excess $\mathrm{H}_{2} \mathrm{SO}_{4}$ to bring $\mathrm{pH}$ down to 4 , then neutralization to $\mathrm{pH} 7$ by lime before filtration.

The appropriateness of the iron addition ( $0.001 \mathrm{M}$ ) selected can be questioned. It might appear from the molar ratio of iron to phosphate upwards of 2 implied as necessary by Fig. 23 for removal of phosphate to low levels that at higher phosphate concentrations encountered in feed (Figs: 7 and 8 ) fifty $\mathrm{mg} / \ell$ of iron would be insufficient. However, with few exceptions this level has reduced phosphate in filtrate to less than $1 \mathrm{mg} / \ell$ and we believe it adequate. Possibly more phosphate is removed when the $\mathrm{Fe}$ (III) hydrolyzes and precipitates in the feed, rather than when the feed contacts iron added earlier, as was the case for most of the results in Fig. 23. There also may be some iron or other substances which remove phosphate in the primary sewage.

A more serious question is the optimum iron level for flux. We mentioned earlier the apparent disagreement between, on the one hand, the indication of Figs. 27 and 32 that ferric concentrations above those necessary to remove phosphate had no slear effect on flux and on the other hand the pronounced effect shown in Fig. 6.23 of Reference 35. A recent experiment, in which primary sewage taken in at the same time was filtered simultaneously in the two trailer loops at two different iron levels $(50 \mathrm{mg} / \ell$ and $200 \mathrm{mg} / \ell$ ), also indicated a substantially higher flux at higher iron concentration. It is of course possible that similar trends are lost in scatter in Figs. 27 and 32 arising from differences in feed from day to day. Differences in test procedures are an alternative possibility. The experiments in which flux increased with additive concentration were carried out at $0 \%$ water recovery, filtrate being recycled to the concentrate tank. In those of Figs. 27 and 32, filtrate was discarded, water recoveries being over $75 \%$ at the end of most 24 -hour runs. Since additive was added to feed at a constant amount per unit volume, the circulating stream became continually enriched in iron; the Fe(III) concentration at a given time was the number of mg/ $l$ added to incoming feed divided by ( 1 - fractional water recovery), less minor amounts paesed with filtrate. 
The most obvious way to settle the question would be simultaneous experiments with increasing water recovery in the two trailer loops, under conditions identical except for iron concentration. This would require parallel feed pretreatment lines in the van (Fig. 1), which are not now available. We have elected to base this discussion on results of the pattern of Figs. 27 and 32, on the basis that it simulates more closely practical operation than the other. Further, we shall use the conservative 24 -hour average fluxes of about $6.1 \mathrm{~m} / \mathrm{d}\left(150 \mathrm{gpd} / \mathrm{ft}^{2}\right)$ suggested by Fig. 32 (rather than the $210.2 \mathrm{~m} / \mathrm{d}\left(250 \mathrm{gpd} / \mathrm{ft}^{2}\right.$ ) of Fig. 27). For situations where higher fluxes are realized, Fig. 54 allows estimation of the benefits. The possibility, suggested by the results of Fig. 6.23 of Ref. 35, of a tradeoff between cost of higher iron concentration and savings from high flux should also be remembered; this would be particularly attractive in locations where ferrous-containing waste streams are available. 4,5

Requirement of acid, in excess of that produced by $\mathrm{Fe}$ (III) hydrolysis, and of base for neutralization vary with the sewage, though not in a way readily predictable, at least from TOC. In four typical runs in which we kept careful account of chemical requirements, $\mathrm{H}_{2} \mathrm{SO}_{4}$ needed to bring the $\mathrm{pH}$ to 4 (50 mg/l iron) varied from 0.0011 to 0.0016 moles $/ \ell$ of primary; for cost estimates we used the average, 0.0014 (Table 10). Sodfum hydroxide addition, after $\mathrm{CO}_{2}$ had been removed by air sparging, needed to raise $\mathrm{pH} 4$ solutions to $\mathrm{pH} 7$ ranged in three runs from 0.0018 to 0.0033 moles $\mathrm{NaOH} /$ liter, the average being 0.0026 . About half of this brought $\mathrm{pH}$ from 4 to 6 ; other runs required about the same average amount to reach $\mathrm{pH} 6$ from 4. If $\mathrm{NaOH}$ at $16.5 \mathrm{c} / \mathrm{kg}(6.5 \mathrm{c} / \mathrm{lb})$ were used, the neutralization from $\mathrm{pH} 4$ to $\mathrm{pH} 7$ would cost nearly $1.8 \mathrm{c} / \mathrm{m}^{3}(7 \mathrm{c} / \mathrm{kgal})$. However, 1ime, which costs only about a seventh as much per equivalent of hydroxide, appears equally satisfactory.

Filteraid application of about $10 \mathrm{mg} / \mathrm{cm}^{2}$ of filtering surface are typical of the rather thick coats with which flux was maintained over the many successive runs of Fig. 49. Asbestos was used in most of these, but about the same amount seems to be needed for a thick coat of cellulosic filteraid. Estimate of filteraid precoat cost in Table 10 is based on 24-hour cycles, the average flux for the period being $6.1 \mathrm{~m} / \mathrm{d}$ (150 $\left.\operatorname{gpd} / \mathrm{ft} \mathrm{t}^{2}\right)$. 
The sum of these chemical costs (Table 10) is a little over $3.3 \mathrm{c} / \mathrm{m}^{3}$ (13c/kga1). Introduction of iron as other commercially available salts did not alter cross-flow filtration performance significantly. There would be little cost difference, according to current issues of Chemical Marketing, if ferric chloride were used instead of ferrous sulfate and ferric sulfate might be a little cheaper; there is some question concerning the \% $\mathrm{Fe}$ in the various industrial grades of all these chemicals. Aluminum introduced as aluminum sulfate (at $\$ 68 /$ metric ton ( $\$ 62 /$ ton), $17 \% \mathrm{Al}_{2} \mathrm{O}_{3}$ ) would cost about a third more per mole than $\mathrm{Fe}(\mathrm{II})$.

\section{Other Costs}

Ref. 29 dealt only with the cross-flow filtration operation, and did not include provision for the chemical pretreatment steps projected here. We contemplate that these operations would be done by extending the primary sewage effluent channel to include two more compartments, also isolated by weirs, in the layout of Fig. 57. In the first, iron salts and acid would be added with aeration, and in the second, $\mathrm{pH}$ would be adjusted to the level selected for filtration, again with aeration to complete oxidation of $\mathrm{Fe}$ (II) to $\mathrm{Fe}$ (III). It may be feasible to combine the neutralizing compartment with the first tier, particularly if iron is added as $\mathrm{Fe}$ (III) or if $\mathrm{Al}$ (III) is used. We have not estimated in detail what the added cost would be, but by analogy with aeration processes, $^{38}$ an increment of about $4 c / \mathrm{kgal}$ seems reasonable for the addition of two compartments and associated equipment.

\section{Comments}

The estimated costs for the selected case are summarized in Table 11. The total, $46 \mathrm{c} / \mathrm{kgal}$ or $12 \mathrm{c} / \mathrm{m}^{3}$, is based, we believe, on a rather conservative set of assumptions, with the possible exception of electricity costs. We used, for example, a non-automated plant with seven pumping circuits, because this seems to present the fewest challenges in design of initial units and is less risky, in that breakdown of a single circuit would affect a smaller fraction of total capacity than if only three p.c. were used. Had the automated plant with three pumping circuits been selected, costs would have been about $2 c / \mathrm{m}^{3}$ ( $8 \mathrm{c} / \mathrm{kgal}$ ) cheaper. Or if the average 
Table 10. ESTIMATED TYPICAL CHEMICAL COSTS IN CROSS-FLOW FILTRATION OF PRIMARY SEWAGE EFFLUENT

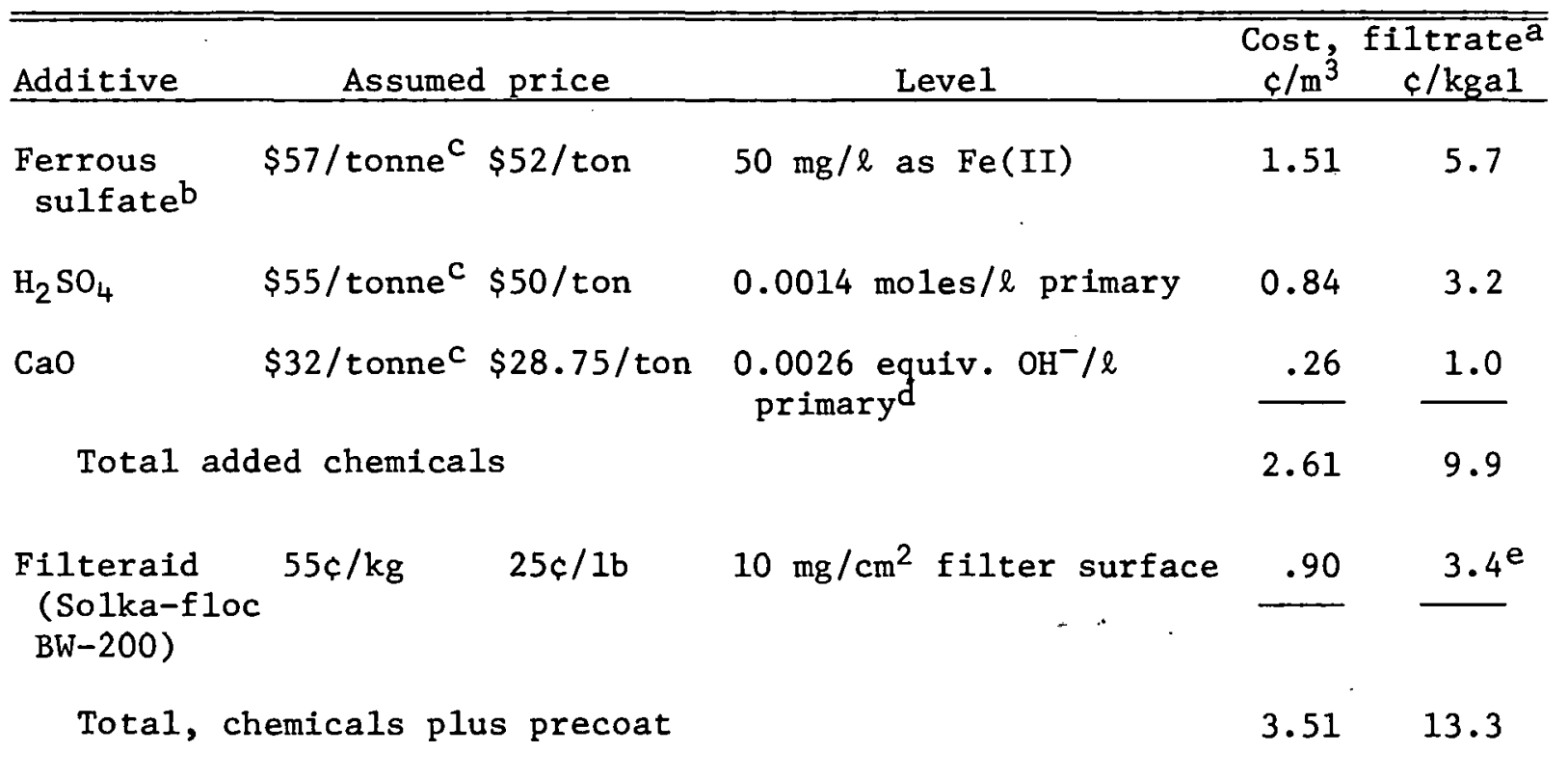

assumed $95 \%$ water recovery

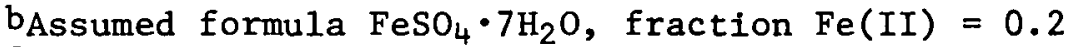

$\mathrm{c}_{\text {Tonne }}$ is metric ton

$\mathrm{d}_{\text {Assumed }} \mathrm{pH}$ adjusted to 7 for filtration

eAssumed daily application, $6.1 \mathrm{~m} / \mathrm{d}\left(150 \mathrm{gpd} / \mathrm{ft}^{2}\right)$ average flux

Table 11. SUMMARY OF ESTIMATED COSTS OF CROSS-FLOW FILTRATION OF PRIMARY SEWAGE EFFLUENTa

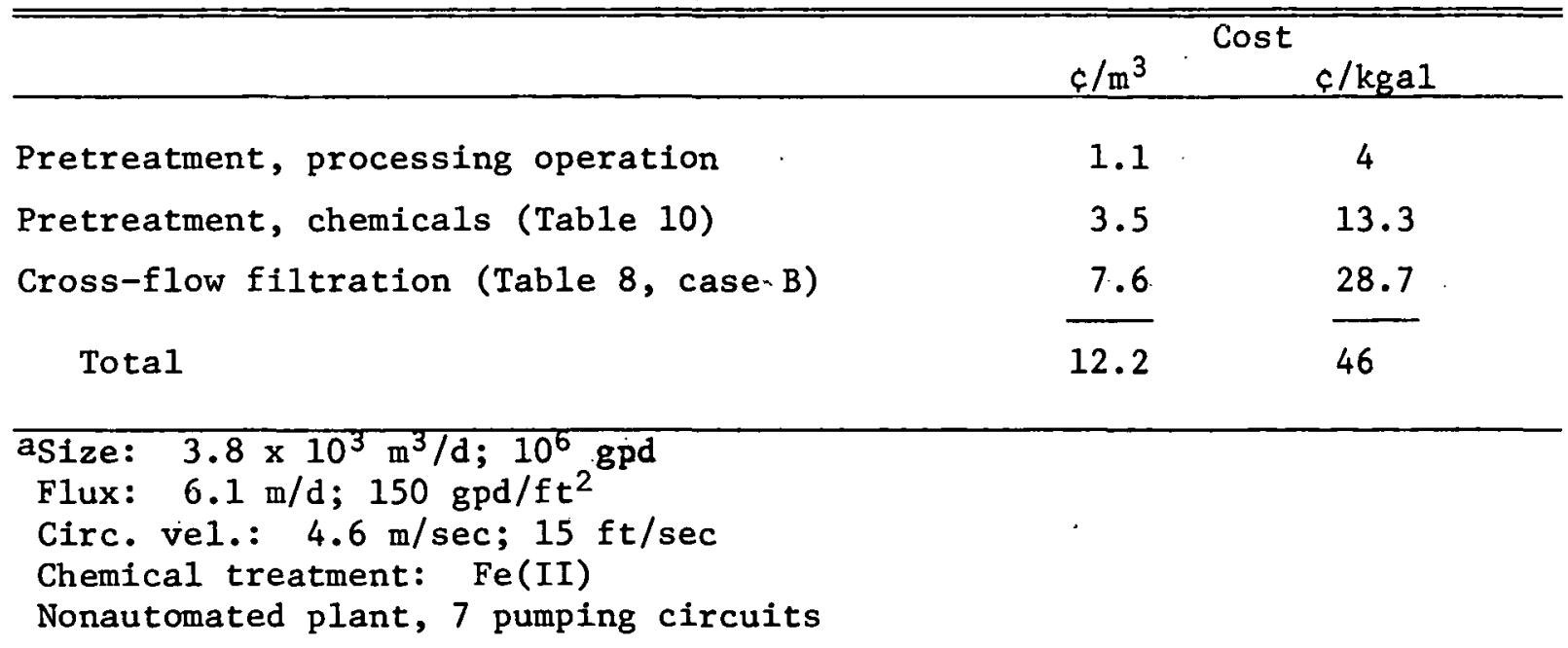


production rate had been $10.2 \mathrm{~m}^{3} / \mathrm{d}\left(250 \mathrm{gpd} / \mathrm{ft}^{2}\right.$ ) (suggested by Fig. 27), costs would have been about $1.6 / \mathrm{m}^{3}$ ( $6 \mathrm{c} / \mathrm{kgal}$ ) lower. If backwashes with coats of filteraid as thin as those of Fig. 48 laid at high circulation velocity were able to maintain fluxes in successive regenerations as well as those with the thicker coats typical of Fig. 49, the precoat cost of Table 10 would be greatly reduced, perhaps to a negligible level. Use of chemical or other regeneration procedures at intervals of a few runs may make this feasible, even if thin coats give less protection.

Major potential for savings, particularly in view of the sharp recent escalation in energy costs, may lie in operation at lower circulation velocities. Fluxes will be lower, but capital costs, outside of expenses for more filter surface, may not necessarily be substantially higher. Lower circulation velocity entails lower pressure drop per unit length which will tend to compensate increases in pumping volume necessary at lower flux. If regeneration procedures illustrated in Fig. 50 were proven adequate over extended periods, inside flow with hoses would make shifts to lower circulation velocity particularly attractive, since additions to filtering surface would be relatively cheap. Even in small lots $(305 \mathrm{~m} ; 1000 \mathrm{ft}$ ), recent purchases of fire-hose jackets have been only a little over $\$ 1 / \mathrm{ft}^{2}$, and probably fabrics designed with optimum characteristics for this application would not be much more expensive in commercial quantities.

In the experiment of Fig. 44, PAC was added to primary sewage at an initial high charge, with no further addition as sewage was processed. If the run had been interrupted when the average usage of PAC was about $500 \mathrm{mg} / \mathrm{l}$, in the range recommended by a group who ran tests with contional separations procedures, ${ }^{10}$ average flux would have been in excess of $16 \mathrm{~m} / \mathrm{d}\left(400 \mathrm{gpd} / \mathrm{ft}^{2}\right)$. At that rate, cost of the cross-flow filtration for the case comparable to Table 11 would be about $4.8 \mathrm{c} / \mathrm{m}^{3}$ (18c/kgal), and an upper limit on chemical cost (at $22 \mathrm{c} / \mathrm{kg}$, or $10 \mathrm{c} / \mathrm{lb} \mathrm{PAC}$ ), no PAC regeneration assumed, would be a little over $10 \mathrm{c} / \mathrm{m}^{3}(40 \mathrm{c} / \mathrm{kgal})$. Cost of regeneration seems uncertain at present, but for service of a $3.8 \times 10^{4}$ $\mathrm{m}^{3} / \mathrm{d}\left(10^{7} \mathrm{gpd}\right)$ plant, recent published estimates vary from less than $2 \mathrm{c} / \mathrm{kg}(1 c / 1 \mathrm{~b})^{10}$ to perhape $9 \mathrm{c} / \mathrm{kg}(4 c / 1 \mathrm{~b})^{7}$ of PAC. Particularly when low TOC in product is important and phosphorus removal secondary, cross-flow 
filtration of PAC-treated sewage may well be attractive, though carbon regeneration at the $3.8 \times 10^{3} \mathrm{~m}^{3} / \mathrm{d}\left(10^{6} \mathrm{gpd}\right)$ level discussed here will likely be somewhat costlier. We have filtered with cross-flow slurries at concentrations in excess of 10 weight \% PAC; from $10 \mathrm{cc}$ of concentrate, centrifugation separated a $5.5 \mathrm{cc}$ bed of PAC. Filtration itself went smoothly, and product was clear, though there was difficulty in pump operation. The test took place before mechanical seals were installed, and the slurry tended to degrade pump seals.

Comparisons with the cost of alternative sewage treatments are uncertain at the present stage of development of this approach, but it appears probable that costs, for example those summarized in Table 11, are considerably higher than those of biological secondary for a plant of similar size. However, additional treatments to the secondary effluent to bring it to the quality of cross-flow filtrate with respect to phosphate content, turbidity, and bacterial contamination would likely raise the total treatment cost to a level comparable to or above that of filtration. The advantages of the cross-flow filtration approach are likely initially to be greater for a small installation in situations where reliability requirements are important and space is limited.

FUTURE WORK

The patterns of operation utilizing cross-flow filtration described here, when used in place of standard biological secondary treatment, give water of quality in many respects superior to the effluent from conventional procedures. Operation should be more reliable, space requirements less, and various options (Fe(III) and/or PAC, for example) allow flexi- bility to meet variations in feed compositions and in effluent requirements. The cross-flow filtration units should be amenable to modular construction, with the benefits which large-scale centralized production might'realize.

- We enumerated in Recommendations the next steps we belleve should be taken in development of this concept. These can be classed as finding answers to outstanding questions accessible to small-scale tests, component development, and demonstration. 
In several significant areas, there are uncertainties which could be cleared up by further experiments of the type discussed in this report. Since many of these involve fixing more definitively the effect of variations in chemistry, the most expeditious route would be to add a second pretreatment line for the other loop, so that simultaneous high-waterrecovery tests could be carried out under conditions identical except for the variable under investigation. In this way effects of day-to-day variations of sewage composition on results would be minimized. Some important parameters whose effect should be better defined are effect of $\mathrm{Fe}$ (III) concentration; differences in $\mathrm{Fe}$ (III) and $\mathrm{Al}$ (III), and of the iron salt used; effect of $\mathrm{pH}$, both in filtration and in the acid step during $\mathrm{Fe}$ (III) or Al(III) pretreatment; effect of different patterns of addition, e.g., heavy initial charge of Fe(III), and small additions to incoming sewage vs constant additions to incoming sewage; effect of $\mathrm{pH}$ on operation with PAC (there is preliminary evidence that fluxes after $\mathrm{PAC}$ addition are higher at $\mathrm{pH} 4$ than at higher $\mathrm{pH}$ ); and variations In filteraid precoats. We have expressed earlier the opinion that behavior in operation at lower circulation velocities should be explored more completely, but this can be done with equipment at hand.

The unit should also be relocated for a limited time to assess performance with sewage which includes substantial contributions from industrial effluents. A relatively small number of critical tests should indicate the extent experience with sewage from a bedroom-type community cypified by the Oak Ridge plant is applicable to wastes from more mixed sources.

In component development, the important need is design, construction, and testing of modules suitable for use in a practical plant. At a minimum, configurations using both inside and outside flow should be tried. The additional research proposed would not be absolutely necessary for design of a plant, but we belleve it advisable to define better optimum characteristics. Concurrently with research and module development, a small primary sewage plant, perhaps about $10^{5} \mathrm{gpd}$, which is faced with the necessity of adding secondary treatment in the near future, should be found and steps taken to arrange for a demonstration plant utilizing essentially the complete primary output. In addition 
to establishing the validity of design based on presently available results and those obtained in continuing work, the demonstration would settle whether or not the concentrate from cross-flow filtration can be adequately handled by recycle through the primary settler. It would also put cost estimates on a firmer basis.

In summary, the reported results indicate that cross-flow filtration can be used in conjunction with physical-chemical additives to produce reliably from primary sewage an effluent superior in quality to that from conventional biological secondary treatment. Analogous capabilities for other waste waters can be inferred, and other studies ${ }^{19}$ involving solidsliquid separations, in removal of toxic substances and in treatment of industrial wastes, suggest that the approach indeed may be useful. Different effluents are specific in character, however, and individual tests and development of appropriate procedures are required before conclusions concerning applicability can be drawn. Municipal sewage ttself probably varies enough in composition to require local tests before design of a cross-flow filtration system for treatment. 


\section{REFERENCES}

1. Kreiss1, J. F., and J. J. Westrick. Municipal Waste Treatment by Physical-Chemical Methods. In: Proceedings of Conference on Applications of New Concepts of Physical-Chemical Wastewater Treatment, sponsored by The International Conference on Water Pollution Research and The American Institute of Chemical Engineers, Vanderbilt University, Nashville, Sept. 1972, Eckenfelder, W. W., and L. K. Cecil (eds.). New York, Pergamon Press, 1972. pp. 1-11.

2. Weber, W. J., Jr. Physicochemical Systems for Direct Wastewater Treatment. In: Proceedings of Conference on Applications of New Concepts of Physical-Chemical Wastewater Treatment, sponsored by The International Conference on Water Pollution Research and The American Institute of Chemical Engineers, Vanderbilt University, Nashville, Sept. 1972, Eckenfelder, W. W., and L. K. Cecil (eds.) New York, Pergamon Press, 1972. pp. 13-25.

3. Alvord, E. T., D. M. Gaughan, C. M. Marr, T. Colpetzer, and D. B. Rose. Phosphorus Removal by Ferrous Iron and Lime. Rand Development Corporation and County of Lake, Ohio, performing organizations. U. S. Government Printing Office Report WPCRS 11010 EGO 01/71. U. S. Environmental Protection Agency, Jan. 1971. 71 pp.

4. Leary, R. D., L. A. Ernest, R. S. Powell, and R. M. Manthe. Phosphorus Removal with Pickle Liquor in an Activated Sludge Plant. Sewerage Commission of the City of Milwaukee. U. S. Government Printing Office Report WPCR 11010 FLQ 03/71. U. S. Environmental Protection Agency. March 1971. 143 pp.

5. Leary, R. D., L. A. Ernest, R. S. Powell, and R. M. Manthe. 200 MGD Activated Sludge Plant Removes Phosphorus by Pickle Liquor. Sewerage Commission of the City of Milwaukee. U. S. Government Printing Office Report EPA-670/2-73-050. U. S. Environmental Protection Agency. Sept. 1973. 127 pp.

6. Wilson, T. E. P. J. Yonikas, and G. Lukasik. Waste Pickling Liquor Fur the Removal of Phosphorus in a Municipal Wastewater Treatment Plant. In: Water - 1973, AIChE Symp. Series, Vol. 136, Bennett, f. F. (ad.). New York. AIChE, 1974. py. 350=357. 
7. Burns, D. E., and G. L. She11. Physical-Chemical Treatment of a Municipal Wastewater Using Powdered Carbon. Envirotech Corporation, performing organization. U. S. Government Printing Office Report EPA-R2-73-264. U. S. Environmental Protection Agency. August 1973. pp. 657-669.

8. Shell, G. L., and D. E. Burns. Powdered Activated Carbon. Application, Regeneration and Reuse in Wastewater Treatment Systems. In: Advances in Water Pollution Research, Proc. "Sixth Int. Conf., Jerusalem, June 1972, Jenkins, S. H. (ed.). New York, Pergamon Press, 1972. pp. 657-669.

9. Beebe, Richard L. Activated Carbon Treatment of Raw Sewage. Westinghouse Electric Corporation; performing organization. U. S. Government Printing Office Report EPA-R2-73-183. U. S. Environmental Protection Agency. March 1973.

10. Shuckrow, A..J., G. W. Dawson, and W. F. Bonner. Powdered Activated Carbon Treatment of Combined and Municipal Sewage. Battelle Pacific Northwest Laboratories, performing organization. U. S. Government Printing Office Report EPA-R2-73-149. U. S. Environmental Protection Agency, February 1973.

11. Culp, R. L., and G. L. Culp. Advanced Wastewater Treatment. New York, Van Nostrand Reinhold Company, 1971. 310 pp.

12. Bishop, D. F., T. P. O'Farrell, A. F: Cassel, and A. P. Pinto. Physical-Chemical Treatment of Raw Municipal Wastewater. U. S. Government Printing office Report EPA-670/2-73-070. U. S. Environmental Protection Agency: September 1973.

13. Hais, A. B., J. B. Stamberg, and D. F. Bishop. Alum Addition to Activated Sludge with Tertiary Solids Removal. U. S. Government Printing Office Report EPA-670/2-73-037. August 1973.

14. Derrington, R. E., D..H. Stevens, and J.E. Laughlin. Enhancing Trickling Filter Plant Performance by Chemical Precipitation. City of Richardson, Texas, performing organization. U. S. Government Printing Office Report EPA-670/2-73-060. U. S. Environmental Protection Agency. August 1973. 
15. Horstkotte, G. A., Jr. Pilot-Demonstration Project for Industrial Reuse of Renovated Municipal Wastewater. Contra Costa County Water District, performing organization. U. S. Government Printing office Report EPA-670/2-73-064. August 1973.

16. Jahreis, C. A. Shriver Continuous Thicknener. U. S. Patent 2,364,366 (1944). T. Shriver and Co., Inc., Harrison, N. J.

17. Zhevnovatyi, A. I. The Thickening of Suspensions without Cake Formation. Int. Chem. Eng. 4:124, 1964 .

18. Dahlheimer, J. A., D. G. Thomas, and K. A. Kraus. Hyperfiltration XVII. Application of Woven Fiber Hoses to Hyperfiltration of Salts and Crossflow Filtration of Suspended Solids. I\&EC Process Des. \& Develop. 9:565, 1970 .

19. Kraus, K. A. Cross-flow Filtration and Axial Filtration. Paper presented at 29th Annual Purdue Industrial Waste Conference, Lafayette, Indiana, May 7-9, 1974. To be published in proceedings.

20. Nelson, F., H. O. Phtllips, and K. A. Kraus. In: Chemistry Division Annual Report for the Period ending May 20, 1972. ORNL-47.91. pp. 88-90.

21. Desaulniers, C. W., and R. W. Hãusslein. Ultrafiltrative Dewatering of Spent Powdered Carbon. Amicon Corporation, performing organization. U. S. Government Printing Office Report ORD 17020 DBA 03/70. U. S. Federal Water Quality Administration. March 1970.

22. Perona, J. J., J.D. Hutchins, A. M. Rom, J. S. Johnson, Jr., and W. G. Sisson. A Pllot Plant for Sewage Treatment by Cross-Flow Filtration. ORNL TM-4659, 1974.

23. Murtha, S. A., R. Filiba, J. S. Newman, and R. D. Orlandi. Characterization of ORNL's Cross-Flow Filtration Plant for Treating Primary Sewage Effluent. MIT School of Chemical Engineerting Practice, nak Ridge Station. ORNL-MIT-189, 1974.

24. Standard Methods for the Examination of Water and Wastewater, American Public Health Association, Inc., 12th Ed., Washington, D. C., 1965. $769 \mathrm{pp}$. 
25. Thomas, D. G., and R. B. Gallagher. Hydrodynamic Flux Control for Waste Water Application of Hyperfiltration Systems. Oak Ridge National Laboratory, performing organization. U. S. Government Printing Office Report EPA-R7-73-228, U. S. Environmental Protection Agency, May 1973.

26. Johnson, J. S., Jr. Polyelectrolytes in Aqueous Solutions--Filtration, , Hyperfiltration, and Dynamic Membranes. In: Reverse Osmosis Membrane Research, H. K. Lonsdale and H. E. Podall (eds.). Plenum Publishing Company, 1972. p. 379 .

27. Coulson, J. M., and J. F. Richardson. Chemical Engineering, Vol. 2. Pergamon Press, 2nd Ed., 1968. p. 50.

28. Porter, M. C. Concentration Polarization with Membrane U1trafiltration. Ind. Eng. Chem. Prod. Res. Develop. 11:234, 1972.

29. Wadia, P. H., K. A. Kraus, A. J. Shor, and L. Dresner. Preliminary Economic Analysis of Cross-Flow Filtration. Oak Ridge National Laboratory Report, ORNL 4729, August 1973.

30. Hsu, Pa Ho. Complementary Role of Iron(III), Sulfate and Calcium in Precipitation of Phosphates from Solution. Environmental Letters. 5(2):115-136, 1973 .

31. Chaeremi, M., and H. L. Recht. Precipitation of Polyphosphates with Aluminum and Ferric Salts. In: Proceedings of the 25th Industrial Waste Conference, May 5-7, 1970, Purdue University, Part One, 1970. Pp. 356-364.

32. Savage, H. C., N. E. Bolton, H. O. Phillips, K. A. Kraus, and J. S. Johnson, $\mathrm{Jr}$. Hyperfiltration of Plant Effluents. Water and Sewage Works. $116: 102,1969$.

33. Kraus, K. A., J. A. Dahlheimer, and W. R. Mixon. Application of Hyperfiltration to Treatment of Municipal Sewage Effluents. Water Research Program, Oak Ridge National Laboratory. U. S. Government Printing office Report WPCRS ORD 17030FOHO1/70. January 1970. 71 pP.

34. Mahlman, H. A., K. A. Kraus, and W. G. Sisson. In: Chemistry Division Annual Report for the period ending May 20, 1971. Oak Ridge National Laboratory Report ORNL-4706, September 1971. pp. 148-149. 
35. Mah1man, H. A., W. G. Sisson, J. S. Johnson, K. A. Kraus, and N. Harrison. In: Chemistry Division Annual Report for the period ending May 20, 1972. Oak Ridge National Laboratory Report ORNL-4791, August 1972. pp. 100-101.

36. Cohen, J. M. Reference 8, discussion.

37. Nelson, F., H. O. Phillips, and K. A. Kraus. Adsorption of Inorganic Materials on Activated Carbon. Paper presented at 29 th Annual Purdue Industrial Waste Conference, Lafayette, Indiana, May 7-9, 1974. To be published in Proceedings.

38. Smith, R. Cost of Conventional and Advanced Treatment of Wastewaters. Federal Water Pollution Control Administration, Cincinnati Water Research Laboratory. PB 182158. July 1968. 
Certain aspects of the work described in this report were discussed in References 19 and 27. Preliminary results were also reviewed by J. D. Henry, in a chapter on cross-flow filtration in "Recent Developments in Separation Science," Volume II, p. 205, edited by N: N. Li, CRC Press, 1972.

Two patents were based on results obtained in this program:

Kraus, K. A., and H. A. Mahlman. Cross-Flow Filtration Process for Removal of Total Organic Carbon and Phosphates for Aqueous Sewage Effluents. U. S. 3,733,265. May 15, 1973.

Mahlman, H. A., and W. G. Sisson. Cross-Flow Filtration Process. U. S. 3,835,040. September 10, 1974.

A third was partially derived from this work:

Kraus, K. A. Process for Treatment of Aqueous Suspensions.

U. S. 3,778,366. December 11, 1973.

A11 three are assigned to the U. S. Government. 
bar

BOD

$\mathrm{cm} / \mathrm{min}$

COD

$\mathrm{ft} / \mathrm{sec}$ (or fps)

gm

gpd

$\operatorname{gpd} / \mathrm{ft}^{2}$ (or gfd)

gpm

$\mathrm{J}$

JT.U

$\mathrm{kg}$

$\operatorname{kga} 1$

kwh (or kwhr)

$\ell$

$\mathrm{m}$

$\mathrm{m}^{3}$

$\mathrm{m} / \mathrm{d}$

$\mathrm{m}^{3} / d$

$\mathrm{m} / \mathrm{sec}$

mg
Pressure $\left(1\right.$ bar $\left.=10^{5} \mathrm{~N} / \mathrm{m}^{2}=0.987 \mathrm{~atm}=14.50 \mathrm{psi}\right)$

Biological oxygen demand

Flux through filter in cubic centimeters per square centimeter per minute $(1 \mathrm{~cm} / \mathrm{min}=14.40 \mathrm{~m} / \mathrm{d}=$ $354 \mathrm{gpd} / \mathrm{ft}^{2}$ )

Chemical oxygen demand

Circulation or cross-flow velocity (flow of solution being filtered parallel to filtering surface) in feet per second

Gram

Gallons (US) per day ( 1 gallon (US) $=3.785$ \&)

Flux in gallons (US) per square foot of filtering surface per day $\left(1 \mathrm{gpd} / \mathrm{ft}^{2}=0.00283 \mathrm{~cm} / \mathrm{min}=0.0407 \mathrm{~m} / \mathrm{d}\right)$

Gallons (US) per minute

Flux

Jackson Turbidity Unit (measured here with Hach 2100 turbidimeter)

Kilogram

1000 (US) gallons ( $1 \mathrm{kgal}=3.785 \mathrm{~m}^{3}$ or approximately 3.785 metric tons of water)

Kilowatt hour

Liter

Meter

Cubic meter; if water, approximately a metric ton

F1.11x in cubic meters per square meter per day $(1 \mathrm{~m} / \mathrm{d}=$ $24.6 \mathrm{gpd} / \mathrm{ft}^{2}=0.0694 \mathrm{~cm} / \mathrm{min}$ )

Cubic meters per day $\left(1 \mathrm{~m}^{3} / \mathrm{d}=264.2 \mathrm{gpd}\right)$

Circulation velocity in meters per second

Milligram 


\begin{tabular}{|c|c|}
\hline $\mathrm{N} / \mathrm{m}^{2}$ & $\begin{array}{l}\text { Pressure in Newtons per square meter }\left(1 \mathrm{~N} / \mathrm{m}^{2}=\right. \\
\left.1.450 \times 10^{-4} \text { psi }=10^{-5} \text { bar }\right)\end{array}$ \\
\hline PAA & Polyacrylic acid \\
\hline PAC & $\begin{array}{l}\text { Powdered activated carbon (Aqua Nuchar A used in this } \\
\text { work) }\end{array}$ \\
\hline ppm & $\begin{array}{l}\text { Part per million; for dilute aqueous solutions here, } \\
\text { approximately mg/l }\end{array}$ \\
\hline psi or psig & $\begin{array}{l}\text { Pressure in pounds per square inch, measured by gauge } \\
\left(1 \text { psi }=6895 \mathrm{~N} / \mathrm{m}^{2}\right)\end{array}$ \\
\hline TOC & $\begin{array}{l}\text { Total organic carbon, measured here by Beckman } 915 \\
\text { analyzer }\end{array}$ \\
\hline Tonne & $\begin{array}{l}\text { Metric ton ( } 1000 \mathrm{~kg}, 2,204.6 \text { pounds avoirdupois); if } \\
\text { water, approximately } 1 \mathrm{~m}^{3}\end{array}$ \\
\hline & Circulation velocity \\
\hline
\end{tabular}


TECHNICAL REPORT DATA

\begin{tabular}{|c|c|}
\hline \multicolumn{2}{|c|}{$\begin{array}{l}\text { TECHNICAL REPORT DATA } \\
\text { (Please read Instructions on the reverse before completing) }\end{array}$} \\
\hline $\begin{array}{l}\text { 1. REPORT NO. } \\
\text { EPA-600/2-76-025 }\end{array}$ & 3. RECIPIENT'S ACCESSIONNO. \\
\hline $\begin{array}{l}\text { 4. TITLE AND SUBTITLE } \\
\text { CROSS-FLOW FILTRATION IN PHYSICAL-CHEMICAL TREATMENT }\end{array}$ & $\begin{array}{l}\text { 5. REPORT DATE } \\
\text { Completed November, } 1975\end{array}$ \\
\hline OF MUNICIPAL SEWAGE EFFLUENTS & 6. PERFORMING ORGANIZATION CODE \\
\hline $\begin{array}{l}\text { 7. AUTHOR(S) } \\
\text { Mahlman, H. A., Sisson, W. G., Kraus, K. A., and } \\
\text { Johnson, J. S., Jr. }\end{array}$ & 8. PERFORMING ORGANIZATION REPORT NC \\
\hline $\begin{array}{l}\text { 9. PERFORMING ORGANIZATION NAME AND ADDRESS } \\
\text { Water Research Program, Oak Ridge National Laboratory* }\end{array}$ & $\begin{array}{l}\text { 10. PROGRAM ELEMENT NO. } \\
\text { IBC611. }\end{array}$ \\
\hline $\begin{array}{l}\text { P. O. Box X } \\
\text { Oak Ridge, Tennessee } 37830\end{array}$ & $\begin{array}{l}\text { 11. CONTRACT/GRANT NO. } \\
\text { WQO 14-12-832 } \\
\text { AEC Interagency Agreement } \\
40-191-69\end{array}$ \\
\hline 12. SPONSORING AGENCY NAME AND ADDRESS & $\begin{array}{l}\text { 13. TYPE OF REPORT AND PERIOD COVERED } \\
\text { Fina1, 1970-1975 }\end{array}$ \\
\hline $\begin{array}{l}\text { Environmental Protection Agency } \\
\text { Cincinnati, Ohio } 45268\end{array}$ & 14. SPONSORING AGENCY CODE \\
\hline
\end{tabular}

Operated by Union Carbide Corporation, for the U. S. Energy Research and Development Administration

16. ABSTRACT Cross-flow filtration was tested for separation of water from the effluent of primary or secondary treatment of municipal sewage, after addition of physicalchemical reagents. In this approach, the solution being filtered is pumped parallel to the filter, to slow buildup of flux-limiting filtercake. In most cases, the filtering surfaces were 1-inch fabric tubes, manufactured as fire-hose jackets. Results are presented as functions of pressure, water recovery, circulation velocity, additive concentration and other variables. With Fe(III), Al(III), or powdered activated carbon (PAC) added to Oak Ridge primary sewage effluent, filtrate was superior in quality to eff.Juent from activated sludge secondary treatment, and compared favorably with reported characteristics of sewage treated with similar reagents when solids-liquid separation was accomplished by settling. Turbidities were usually wel1 below 1 JTU, and bacteria were substantially removed. With Fe(III), filtrate total organic carbon (Toc) typically was 10 to $15 \mathrm{mg} / \mathrm{l}$, and phosphate below $1 \mathrm{mg} / \mathrm{l}$. With PAC, TOC was lower, usually about $5 \mathrm{mg} / \mathrm{l}$, but phosphate removal was poor. With $\mathrm{Fe}$ (III) at about $0.001 \mathrm{M}$, average fluxes of about $6 \mathrm{~m} / \mathrm{d}$ ( $150 \mathrm{gpd} / \mathrm{ft}^{2}$ ) appear attainable at $4.6 \mathrm{~m} / \mathrm{sec}$ (15 ft/sec) circulation velocity with 24-hour backwash intervals. On this basis, we estimate filtrate cost for a $3,800 \mathrm{~m}^{3} / \mathrm{d}\left(10^{6} \mathrm{gpd}\right)$ plant using Fe(III) of $12 \mathrm{c} / \mathrm{m}^{3}$ ( $\left.46 \mathrm{c} / \mathrm{kgal}\right)$. There are reasonable possibilities of lower costs. Fluxes and product characteristics are similar when feed is activated sludge secondary effluent, except that Toc is lower.

17. KEY WORDS AND DOCUMENT ANALYSIS

\begin{tabular}{|c|c|c|}
\hline DESCRIPTORS & b.IDENTIFIERS/OPEN ENDED TERMS & c. COSATI Field/Group \\
\hline $\begin{array}{l}\text { *iltration, *Activated carbon, *Chemical } \\
\text { precipitation, Tertiary treatment, Nutrient } \\
\text { removal, Organic matter, Phosphate, Iron, } \\
\text { Turbidity. }\end{array}$ & $\begin{array}{l}\text { *Cross-flow filtration, } \\
\text { *Physical-chemical sewage } \\
\text { treatment, Iron salt } \\
\text { additives, Aluminum salt } \\
\text { additives, TOC removal, } \\
\text { 'hosphate removal, Ultra- } \\
\text { filtration, Oak Ridge }\end{array}$ & $13 \mathrm{~B}$ \\
\hline 18. DISTRIBUTION STATEMENT & $\begin{array}{l}\text { 19. SECURITY CLASS (This Report) } \\
\text { Unclassif ied }\end{array}$ & $\begin{array}{l}\text { 21. NO. OF PAGES } \\
127\end{array}$ \\
\hline Release unlimited & $\begin{array}{l}\text { 20. SECURITY CLASS (This page) } \\
\text { Unclassified }\end{array}$ & 22. PRICE \\
\hline
\end{tabular}

